In cooperation with the Tri-County Regional Planning Commission

\title{
Model Refinement and Simulation of Groundwater Flow in Clinton, Eaton, and Ingham Counties, Michigan
}

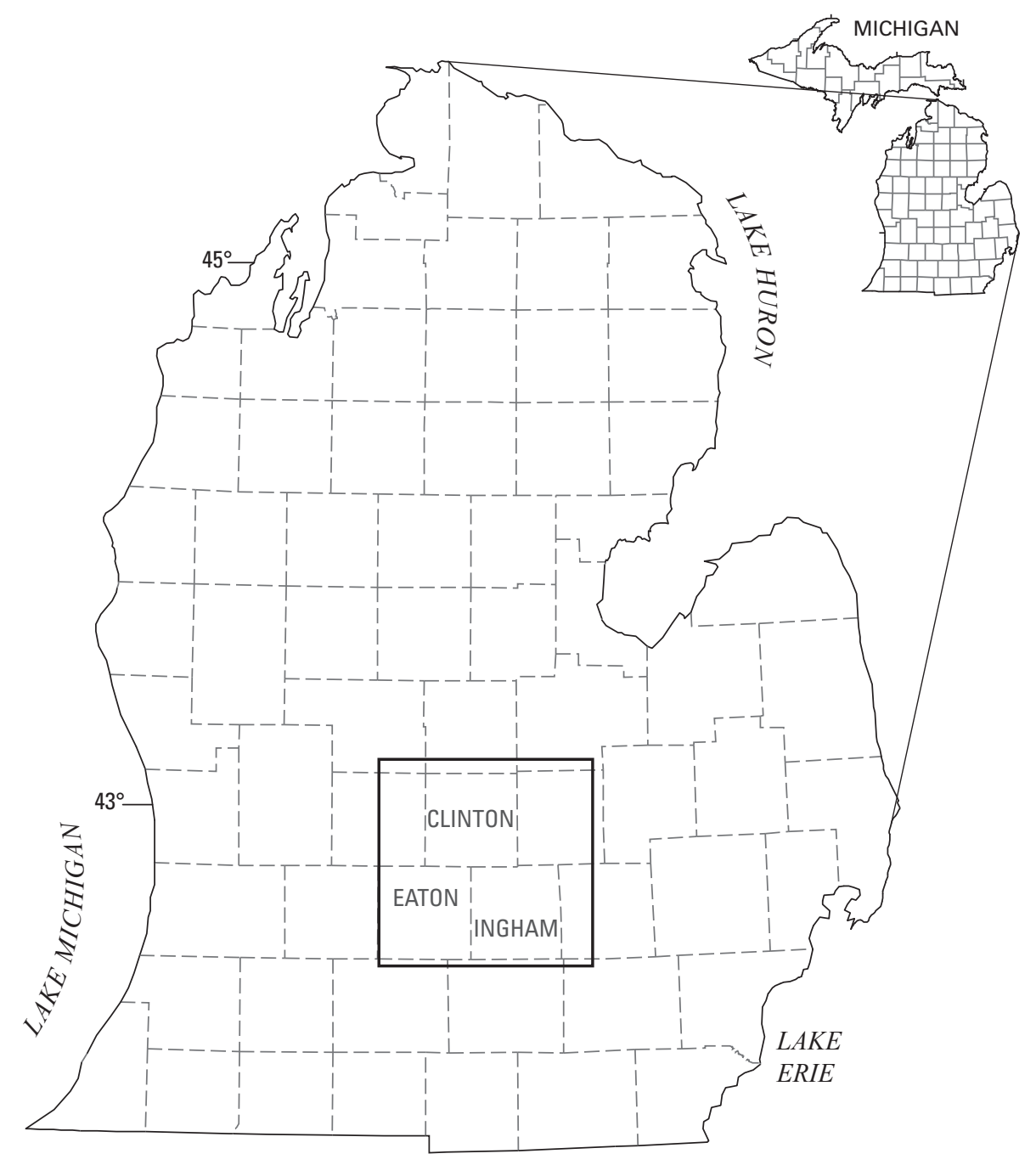

Scientific Investigations Report 2009-5244 



\title{
Model Refinement and Simulation of Groundwater Flow in Clinton, Eaton, and Ingham Counties, Michigan
}

\author{
By Carol L. Luukkonen
}

In cooperation with the Tri-County Regional Planning Commission

Scientific Investigations Report 2009-5244 


\title{
U.S. Department of the Interior \\ KEN SALAZAR, Secretary \\ U.S. Geological Survey \\ Marcia K. McNutt, Director
}

\section{U.S. Geological Survey, Reston, Virginia: 2010}

\author{
For more information on the USGS — the Federal source for science about the Earth, its natural and living resources, \\ natural hazards, and the environment, visit http://www.usgs.gov or call 1-888-ASK-USGS \\ For an overview of USGS information products, including maps, imagery, and publications, \\ visit http://www.usgs.gov/pubprod \\ To order this and other USGS information products, visit http://store.usgs.gov
}

\begin{abstract}
Any use of trade, product, or firm names is for descriptive purposes only and does not imply endorsement by the U.S. Government.

Although this report is in the public domain, permission must be secured from the individual copyright owners to reproduce any copyrighted materials contained within this report.
\end{abstract}

Suggested citation:

Luukkonen, C.L., 2009, Model refinement and simulation of groundwater flow in Clinton, Eaton, and Ingham Counties, Michigan: U.S. Geological Survey Scientific Investigations Report 2009-5244, 53 p. 


\section{Acknowledgments}

The author gratefully acknowledges the assistance of Jon Coleman, Executive Director of the Tri-County Regional Planning Commission, and Christine Spitzley, Environmental Programs Planner of the Tri-County Regional Planning Commission, for their coordination of community involvement, meetings, and distribution of project results. William Maier, Lansing Board of Water and Light (LBWL); Douglas MacDonald, Michigan State University; and Michael St. Bernard, East Lansing and Meridian Township Water Authority, furnished much data on groundwater withdrawals and well characteristics. John Malouin, formerly with the LBWL, supplied geochemical data for Lansing-area wells. Randall Roost, William Maier, and Thomas Savage, LBWL, supplied data for optimization scenarios. The author also appreciates report review comments received from James Brode, associate-senior hydrogeologist, Fishbeck, Thompson, Carr and Huber.

Paul Barlow, USGS hydrologist, assisted with using and interpreting the optimization programs and reviewed the draft report. David Westjohn, formerly with the USGS, provided many hydrogeological and historical insights about the study area and was instrumental in initiating this project. The author also appreciates the assistance of Lori Fuller, USGS geographer, for her interpretation and determination of urban areas from aerial photos, and Michael Eberle, USGS editor, for his review of the draft report. 



\section{Contents}

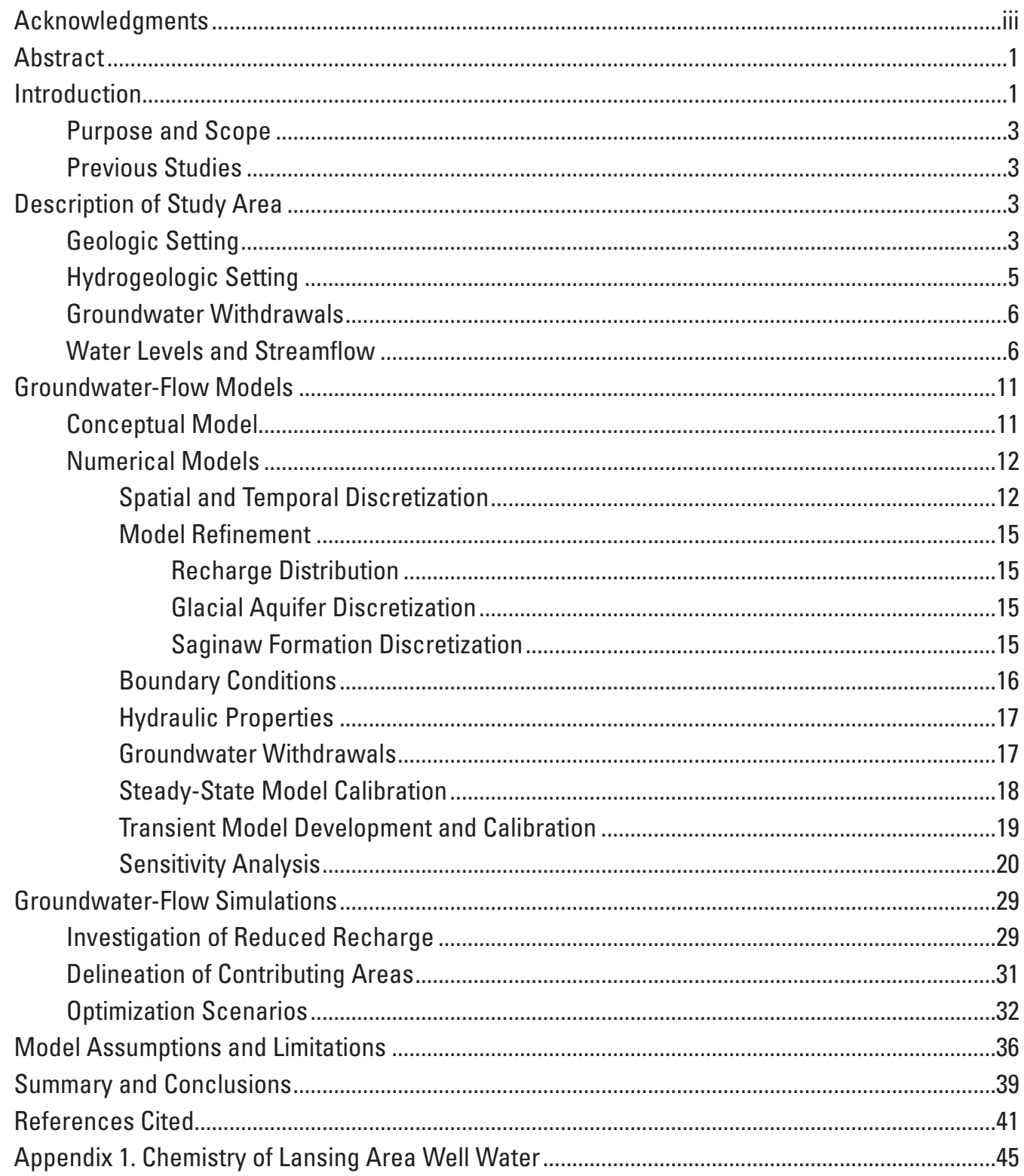

\section{Figures}

1-2. Maps showing:

1. Location of the Tri-County regional model area in the Lower Peninsula of Michigan.

2. Location of communities and the nine-township area surrounding Lansing, Michigan 
3. Diagram showing stratigraphic nomenclature and hydrogeologic units,

Tri-County region, Michigan

4. Map showing groundwater levels in the Saginaw aquifer in the model area,

Tri-County region, Michigan

5-6. Graphs showing:

5. Groundwater withdrawals from the Saginaw aquifer and glacial deposits, Tri-County region, 1910-2005

6. Comparison of groundwater withdrawals from the North and South Lansing areas, Michigan, 1915-2005.

7-8. Maps showing:

7. USGS streamgaging stations and observation wells, Tri-County region, Michigan .

8. Model boundary and refined grid area, Tri-County region, Michigan

9-16. Graphs showing:

9. Annual average precipitation in the Tri-County region, Michigan

10. Relations between simulated water levels in the glacial deposits and Saginaw aquifer, and streamflow from the 1996 and 2009 models in the Tri-County region, Michigan

11. Relation between observed and simulated transient water levels in observation wells in the Lansing area, Michigan ....

12. Relation between observed and simulated transient water levels in Tri-County-region observation wells

13. Relation between observed and simulated transient streamflows in the Tri-County region, Michigan

14. Water-budget components and change in components by stress period, Tri-County model..

15. Net storage, by year, during transient simulations with reduced recharge and reduced recharge with increased pumping.

16. Net storage, by month, during transient simulations with reduced recharge and reduced recharge with increased pumping..

17-20. Maps showing:

17. Simulated 10-year time-of-travel areas for selected production wells in the nine-township area, Tri-County region, Michigan

18. Optimized wells in the Lansing area, Michigan.

19. Optimized wells for areas $A$ and $B$ with a specified maximum pumping rate of 0.5 million gallons per day.

20. Optimized wells for areas $A$ and $B$ with a specified maximum pumping rate of 1 million gallons per day... 


\section{Appendix Figures}

1-1. Graph showing trilinear diagrams of Lansing area, Michigan, groundwater samples. $A$, Total dissolved solids (TDS) concentrations less than 500 ,

and $B$, greater than 1,000 milligrams per liter

1-2. Map showing distribution of hardness, in milligrams per liter $\mathrm{CaCO}_{3^{\prime}}$ from

samples from 2003-5, Lansing area, Michigan

1-3-1-7 Graphs showing:

1-3. Major ion concentrations, in milligrams per liter, for 1930-2006, Lansing area, Michigan

1-4. Major ion concentrations for northern and southern wells for 1930-2005, Lansing area, Michigan

1-5. Trilinear diagrams of water samples collected from northern Lansing area, Michigan, wells $A$, before 1970, and $B$, after 1970

1-6. Relation of chloride to sulfate concentrations collected from northern Lansing area, Michigan, wells $A$, before 1970, and $B$, after 1970

1-7. Comparison of major-ion concentrations from water samples collected from northern Lansing area, Michigan, wells before and after 1970.

\section{Tables}

1. USGS streamgaging stations and observation wells in the Tri-County region, Michigan

2. Transient model details for model representing early 1900 s to 2005 , Tri-County region, Michigan.

3. Parameter estimates for coefficients multiplying matrices that describe the spatial variation of hydraulic properties in the Tri-County region, Michigan

4. Water-level observations used in transient model calibration for the Tri-County region, Michigan

5. Transient model details for monthly stress periods for the Tri-County region, Michigan

6. Summary of optimization formulations and results for the Tri-County region, Michigan 


\section{Conversion Factors and Datums}

\begin{tabular}{|c|c|c|}
\hline Multiply & By & To obtain \\
\hline \multicolumn{3}{|c|}{ Length } \\
\hline inch (in.) & 2.54 & centimeter $(\mathrm{cm})$ \\
\hline inch (in.) & 25.4 & millimeter $(\mathrm{mm})$ \\
\hline foot $(\mathrm{ft})$ & .3048 & meter $(\mathrm{m})$ \\
\hline mile (mi) & 1.609 & kilometer (km) \\
\hline \multicolumn{3}{|c|}{ Area } \\
\hline square foot $\left(\mathrm{ft}^{2}\right)$ & 929.0 & square centimeter $\left(\mathrm{cm}^{2}\right)$ \\
\hline square foot $\left(\mathrm{ft}^{2}\right)$ & .09290 & square meter $\left(\mathrm{m}^{2}\right)$ \\
\hline square mile $\left(\mathrm{mi}^{2}\right)$ & 2.590 & square kilometer $\left(\mathrm{km}^{2}\right)$ \\
\hline \multicolumn{3}{|c|}{ Volume } \\
\hline gallon (gal) & 3.785 & liter (L) \\
\hline gallon (gal) & 0.003785 & cubic meter $\left(\mathrm{m}^{3}\right)$ \\
\hline million gallons (Mgal) & 3,785 & cubic meter $\left(\mathrm{m}^{3}\right)$ \\
\hline cubic foot $\left(\mathrm{ft}^{3}\right)$ & 28.32 & cubic decimeter $\left(\mathrm{dm}^{3}\right)$ \\
\hline cubic foot $\left(\mathrm{ft}^{3}\right)$ & .02832 & cubic meter $\left(\mathrm{m}^{3}\right)$ \\
\hline \multicolumn{3}{|c|}{ Flow and recharge rates } \\
\hline inch per year (in/yr) & 0.3048 & millimeter per year (mm/yr) \\
\hline foot per day $(\mathrm{ft} / \mathrm{d})$ & .3048 & meter per day $(\mathrm{m} / \mathrm{d})$ \\
\hline cubic foot per second $\left(\mathrm{ft}^{3} / \mathrm{s}\right)$ & .02832 & cubic meter per second $\left(\mathrm{m}^{3} / \mathrm{s}\right)$ \\
\hline gallon per day (gal/d) & .003785 & cubic meter per day $\left(\mathrm{m}^{3} / \mathrm{d}\right)$ \\
\hline million gallons per day (Mgal/d) & .04381 & cubic meter per second $\left(\mathrm{m}^{3} / \mathrm{s}\right)$ \\
\hline \multicolumn{3}{|c|}{ Hydraulic conductivity } \\
\hline foot per day $(\mathrm{ft} / \mathrm{d})$ & 0.3048 & meter per day $(\mathrm{m} / \mathrm{d})$ \\
\hline \multicolumn{3}{|c|}{ Transmissivity* } \\
\hline foot squared per day $\left(\mathrm{ft}^{2} / \mathrm{d}\right)$ & 0.09290 & meter squared per day $\left(\mathrm{m}^{2} / \mathrm{d}\right)$ \\
\hline \multicolumn{3}{|c|}{ Leakance } \\
\hline foot per day per foot $[(\mathrm{ft} / \mathrm{d}) / \mathrm{ft}]$ & 1 & meter per day per meter \\
\hline
\end{tabular}

*Transmissivity: The standard unit for transmissivity is cubic foot per day per square foot times foot of aquifer thickness [(ft $\left.\left.\mathrm{ft}^{3} \mathrm{~d}\right) / \mathrm{ft}^{2}\right] \mathrm{ft}$. In this report, the mathematically reduced form, foot squared per day $\left(\mathrm{ft}^{2} / \mathrm{d}\right)$, is used for convenience.

Vertical coordinate information is referenced to the North American Vertical Datum of 1929 (NVGD 29).

Horizontal coordinate information is referenced to the Michigan State Plane Coordinate System, South Zone.

Altitude, as used in this report, refers to distance above the vertical datum.

Concentrations of chemical constituents in water are given either in milligrams per liter (mg/L) or micrograms per liter $(\mu \mathrm{g} / \mathrm{L})$ 


\title{
Model Refinement and Simulation of Groundwater Flow in Clinton, Eaton, and Ingham Counties, Michigan
}

\author{
By Carol L. Luukkonen
}

\section{Abstract}

A groundwater-flow model that was constructed in 1996 of the Saginaw aquifer was refined to better represent the regional hydrologic system in the Tri-County region, which consists of Clinton, Eaton, and Ingham Counties, Michigan. With increasing demand for groundwater, the need to manage withdrawals from the Saginaw aquifer has become more important, and the 1996 model could not adequately address issues of water quality and quantity. An updated model was needed to better address potential effects of drought, locally high water demands, reduction of recharge by impervious surfaces, and issues affecting water quality, such as contaminant sources, on water resources and the selection of pumping rates and locations. The refinement of the groundwater-flow model allows simulations to address these issues of water quantity and quality and provides communities with a tool that will enable them to better plan for expansion and protection of their groundwater-supply systems. Model refinement included representation of the system under steady-state and transient conditions, adjustments to the estimated regional groundwater-recharge rates to account for both temporal and spatial differences, adjustments to the representation and hydraulic characteristics of the glacial deposits and Saginaw Formation, and updates to groundwater-withdrawal rates to reflect changes from the early 1900 s to 2005 .

Simulations included steady-state conditions (in which stresses remained constant and changes in storage were not included) and transient conditions (in which stresses changed in annual and monthly time scales and changes in storage within the system were included). These simulations included investigation of the potential effects of reduced recharge due to impervious areas or to low-rainfall/drought conditions, delineation of contributing areas with recent pumping rates, and optimization of pumping subject to various quantity and quality constraints. Simulation results indicate potential declines in water levels in both the upper glacial aquifer and the upper sandstone bedrock aquifer under steady-state and transient conditions when recharge was reduced by 20 and 50 percent in urban areas. Transient simulations were done to investigate reduced recharge due to low rainfall and increased pumping to meet anticipated future demand with 24 months ( 2 years) of modified recharge or modified recharge and pumping rates. During these two simulation years, monthly recharge rates were reduced by about 30 percent, and monthly withdrawal rates for Lansing area production wells were increased by 15 percent. The reduction in the amount of water available to recharge the groundwater system affects the upper model layers representing the glacial aquifers more than the deeper bedrock layers. However, with a reduction in recharge and an increase in withdrawals from the bedrock aquifer, water levels in the bedrock layers are affected more than those in the glacial layers. Differences in water levels between simulations with reduced recharge and reduced recharge with increased pumping are greatest in the Lansing area and least away from pumping centers, as expected. Additionally, the increases in pumping rates had minimal effect on most simulated streamflows.

Additional simulations included updating the estimated 10-year wellhead-contributing areas for selected Lansing-area wells under 2006-7 pumping conditions. Optimization of groundwater withdrawals with a water-resource management model was done to determine withdrawal rates while minimizing operational costs and to determine withdrawal locations to achieve additional capacity while meeting specified head constraints. In these optimization scenarios, the desired groundwater withdrawals are achieved by simulating managed wells (where pumping rates can be optimized) and unmanaged wells (where pumping rates are not optimized) and by using various combinations of existing and proposed well locations.

\section{Introduction}

The Tri-County region, which consists of Clinton, Eaton, and Ingham Counties, covers 1,697 $\mathrm{mi}^{2}$ in the southcentral part of the Lower Peninsula of Michigan (fig. 1). A groundwater-flow model was developed in 1996 by the U.S. Geological Survey (USGS) to investigate groundwater flow in the Saginaw aquifer (Holtschlag and others, 1996; Luukkonen and others, 1997a, b), which underlies the majority of these three counties. Since compilation of the Tri-County regional groundwater-flow model in 1996, the model has been used frequently to address water-resources issues such as the delineation of contributing areas to local municipal wells as part of local Wellhead Protection Programs. As pumping rates 


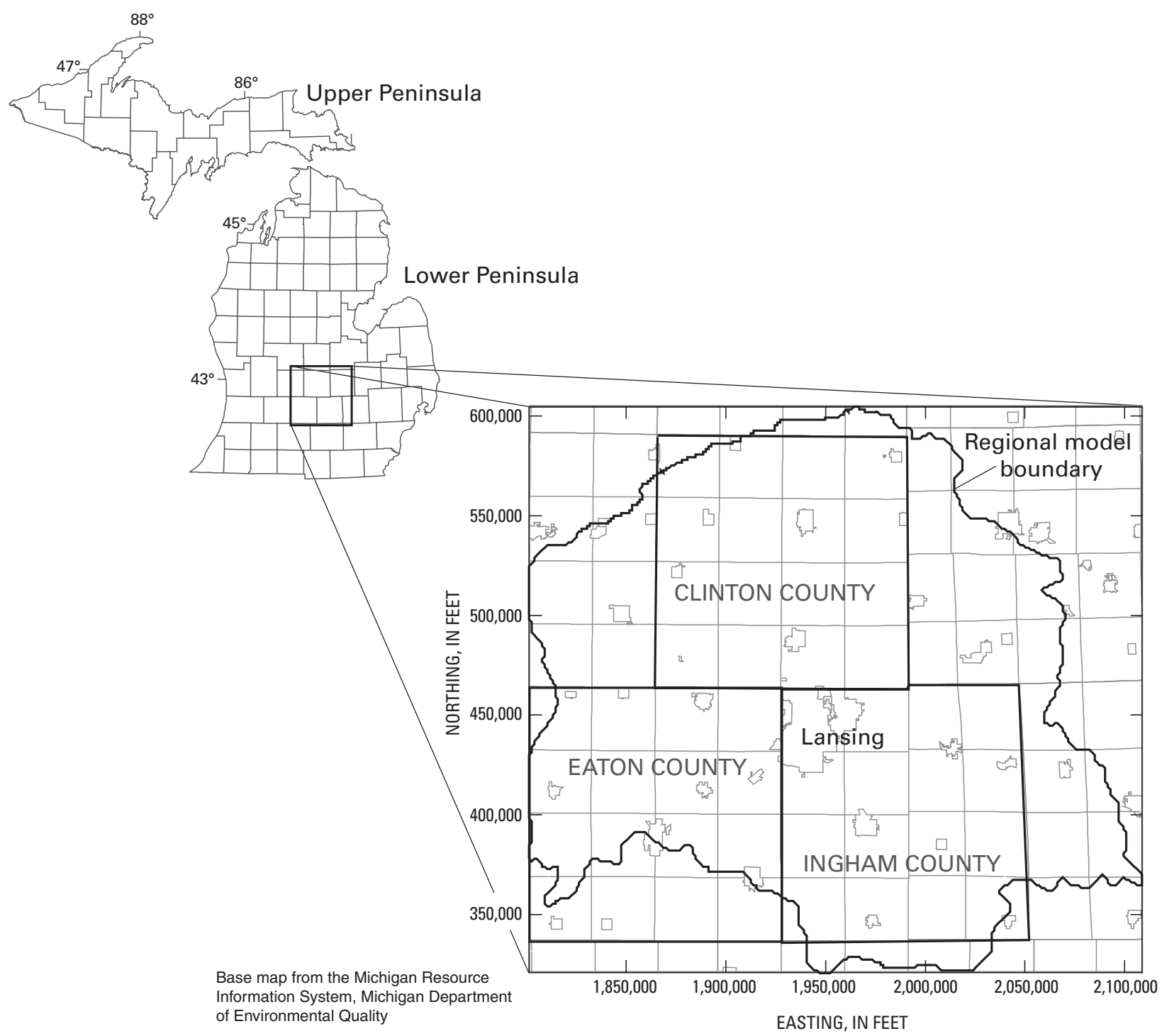

Figure 1. Location of the Tri-County regional model area in the Lower Peninsula of Michigan.

and well locations have changed, these contributing areas have been periodically updated. The 1996 USGS model has also provided insight about new areas for well development and the effects of groundwater withdrawals in these areas, and it has addressed possible effects of proposed options such as injection wells or contamination-remediation wells.

Since 1996, demand for water of sufficient quantity and quality has continued to increase considerably in the greater Lansing area (fig. 2). In fact, use of groundwater exceeded 1 billion gallons for July 2002, a new all-time high (William Maier, Lansing Board of Water and Light (LBWL), oral commun., 2002). The concentration of dissolved solids is increasing in some areas of Lansing's well field (William Maier, LBWL, oral commun., 2003). Additional concerns include potential effects of drought, high water demands, impervious surfaces, and discovery of additional contaminant sources and how each of these may affect water levels, streamflow, and the selection of pumping rates and locations. As a result, the need to manage withdrawals from the Saginaw aquifer has become increasingly important.

The 1996 model is a regional-scale model that required refinement to adequately address these issues of water quality and quantity. Additional information is now available from detailed site-specific models that have been developed in the greater Lansing area and from an electronic database of well records (Wellogic) developed by the Michigan Department of Environmental Quality (MDEQ). Analysis and incorporation of this information would enable model refinements to improve model-prediction capabilities and would provide a means to simulate more complex regional and more localized water-withdrawal scenarios.

In 2004, the Lansing area communities working with the Tri-County Regional Planning Commission (TCRPC) and the USGS began a long-term plan for continued enhancement of the USGS regional groundwater-flow model. Participating communities are Alaiedon Township, Bath Township, Delhi Township, Delta Township, City of East Lansing, 
City of Eaton Rapids, City of Lansing, City of Williamston, Eaton Rapids Township, Lansing Township, Michigan State University, Meridian Township, Oneida Township, Vermontville Township, Village of Dimondale, Watertown Township, Williamstown Township, and Windsor Township (fig. 2). The communities concluded that refinement of the 1996 USGS model would improve understanding of the regional hydrologic system in the Lansing area and help ensure that the model continues to be a valuable tool to assist with planning for expansion and protection of the water supplies of the Lansing-area communities.

\section{Purpose and Scope}

This report describes the refinement of the simulated aquifer and recharge characteristics of the 1996 Tri-County regional groundwater-flow model and the simulations done with this updated model (hereafter referred to as the "2009 model"). The 2009 numerical model is able to simulate the groundwater-flow system under steady-state and transient conditions. Simulation results show potential effects of reduced recharge and increased withdrawals on groundwater levels and streamflow. Particle-tracking analysis was used with results from flow simulations to delineate contributing areas to production wells. Simulation results also show how the model can be used with optimization techniques to evaluate alternative groundwater pumping scenarios under selected management constraints. The limitations of the model for assessing groundwater levels and flow and for delineating contributing areas are described. Characterization of the geochemical changes in water quality revealed by historical data for selected Lansingarea wells is included in the appendix.

\section{Previous Studies}

Several previous studies have contributed to the knowledge of the groundwater resources in the Tri-County region and to the development of the 2009 model. With regard to background conditions, Wood (1969) described the hydrogeology and geochemistry of groundwater in the Saginaw Formation. Vanlier and others (1973) described water-supply development and management alternatives in the Tri-County region. The Tri-County Regional Planning Commission (1992) completed a regional feasibility study on watersupply development.

With regard to groundwater-flow modeling, one of the earliest local efforts was that of Wheeler (1967), who developed an electric analog model of groundwater flow in the Saginaw Formation in the Lansing area, Mich. A report by Holtschlag and others (1996) documents how the regional groundwater-flow model was developed and used to determine contributing areas for most production wells in the Tri-County region. Two reports describe refinement of the original 1996 model using reduced grid spacing and the results of additional groundwater-flow simulations in the north Lansing area (Luukkonen and others, 1997a, b).

\section{Description of Study Area}

In this report, the area in and surrounding Lansing, which is referred to as the "nine-township area," consists of Alaiedon, Bath, Delhi, Delta, Dewitt, Lansing, Meridian, Watertown, and Windsor Townships (fig. 2). The nine-township area is the principal area of groundwater withdrawals in the TriCounty region. Groundwater is withdrawn primarily from the Saginaw aquifer, which consists of water-bearing sandstones within the Grand River and Saginaw Formations of Pennsylvanian age. Aquifers in the glacial deposits and other bedrock units are important groundwater sources in some places. The primary geologic, hydrogeologic, and water-use characteristics that affect groundwater flow in the Saginaw aquifer are described in the following sections.

\section{Geologic Setting}

In the Tri-County region, Cambrian through Pennsylvanian age sedimentary and Upper Jurassic rocks overlie Precambrian basement. Triassic, Lower and Middle Jurassic, and Cretaceous rocks are missing (Mandle and Westjohn, 1989). Glacial deposits of Pleistocene age overlie Pennsylvanian and Upper Jurassic rocks.

Pennsylvanian rocks form the uppermost bedrock unit in the Tri-County region. The altitude of the surface of the Pennsylvanian rocks ranges from about $850 \mathrm{ft}$ in the south to about $600 \mathrm{ft}$ in the north. Pennsylvanian rocks are thickest in the west-central part of Clinton County and generally thin to the south. They are absent in the extreme eastern part of Ingham County.

The stratigraphic relation is not clear between the Saginaw Formation, Parma Sandstone, and the underlying Bayport Limestone (fig. 3). The Parma Sandstone is composed of medium- to coarse-grained sandstone and is generally less than $100 \mathrm{ft}$ thick (Cohee and others, 1951). Interpretation of geophysical logs indicates that the lower part of the Pennsylvanian rock sequence is predominantly shale, whereas the upper part is predominantly sandstone. Thus, the Pennsylvanian rocks younger than the Parma Sandstone can be divided into a lower confining unit and an upper sandstone aquifer (Westjohn and Weaver, 1996).

Discontinuous lenses of sandstone, shale, coal, and limestone in the Pennsylvanian bedrock units have been formally subdivided into two formations. The uppermost massive, coarse-grained sandstones form the Grand River Formation; all remaining Pennsylvanian rocks are considered part of the underlying Saginaw Formation (Mandle and Westjohn, 1989). In Eaton and Ingham Counties, erosion removed most of the Grand River Formation; as a result, only a few large remnants are present today (Vanlier and others, 1973). In Clinton County, the Grand River Formation, although removed by erosion after deposition over a large part of the county, is as much as $125 \mathrm{ft}$ thick in some areas (Vanlier and others, 1973). These assignments between formations are somewhat uncertain, however, because no lithologic differences or stratigraphic 


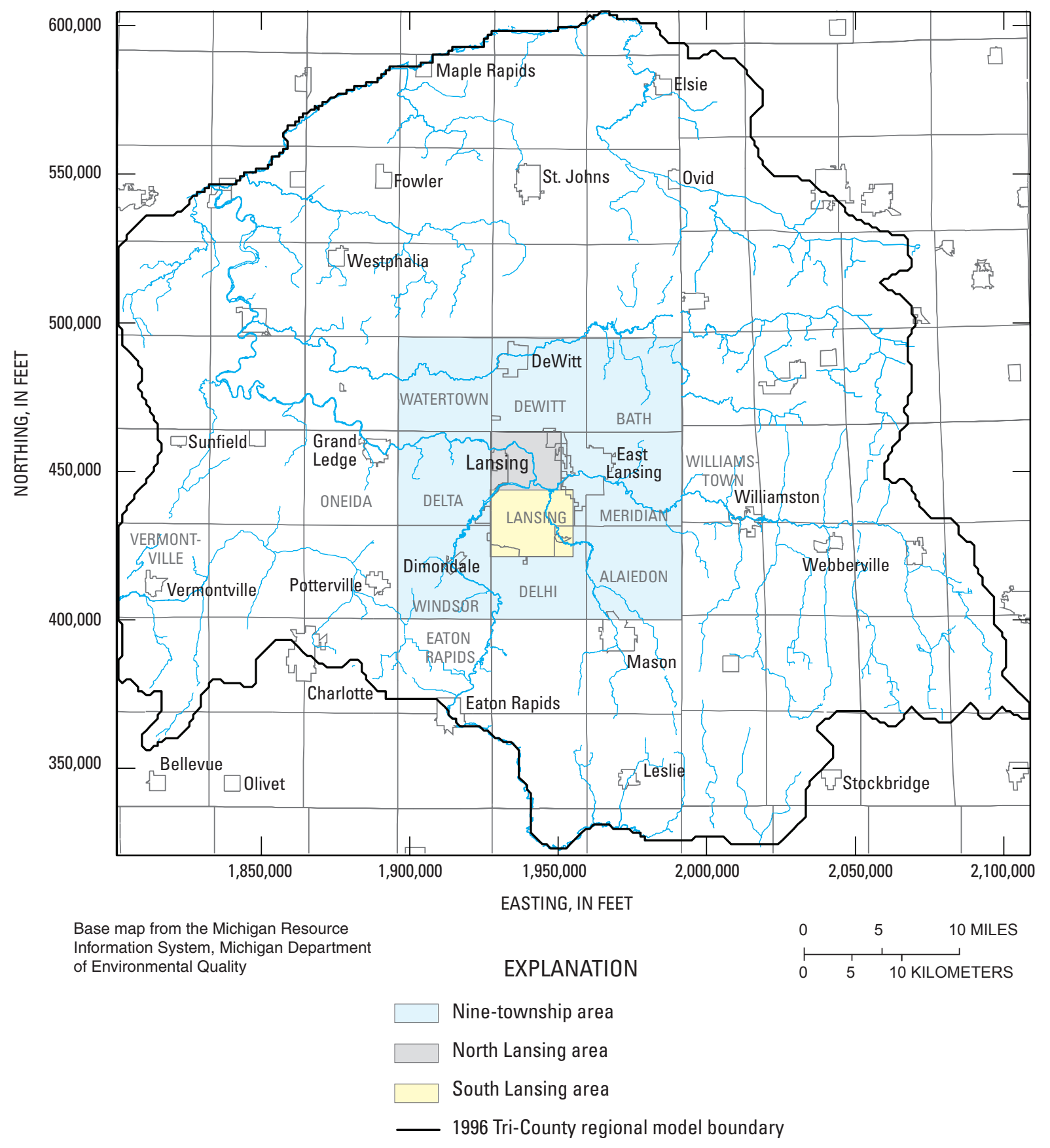

Figure 2. Location of communities and the nine-township area surrounding Lansing, Michigan.

horizons mark a change from one formation to the next (Westjohn and Weaver, 1996).

The Jurassic red beds that separate Pennsylvanian rocks from overlying glacial deposits in some areas of the Lower Peninsula are either entirely absent or only marginally present in the Tri-County region (Westjohn and others, 1994). The red beds are often poorly consolidated or unconsolidated and consist primarily of clay, mudstone, siltstone, sandstone, shale and gypsum. The red beds, which are relatively impermeable and are considered a confining unit, impede the vertical flow of water between glacial deposits and bedrock aquifers (Westjohn and others, 1994). For the purposes of this study, all deposits between the top of the Pennsylvanian rocks and the land surface were assumed to be glacial deposits.

The glacial features in Michigan are the result of ice advances during late Wisconsin time (35,000 to 10,000 years before present). The glacial deposits in Ingham County range in thickness from less than $10 \mathrm{ft}$ to more than $300 \mathrm{ft}$. The glacial deposits are absent in a small area near Grand Ledge; the thickest glacial deposits are in the northwestern part of the 


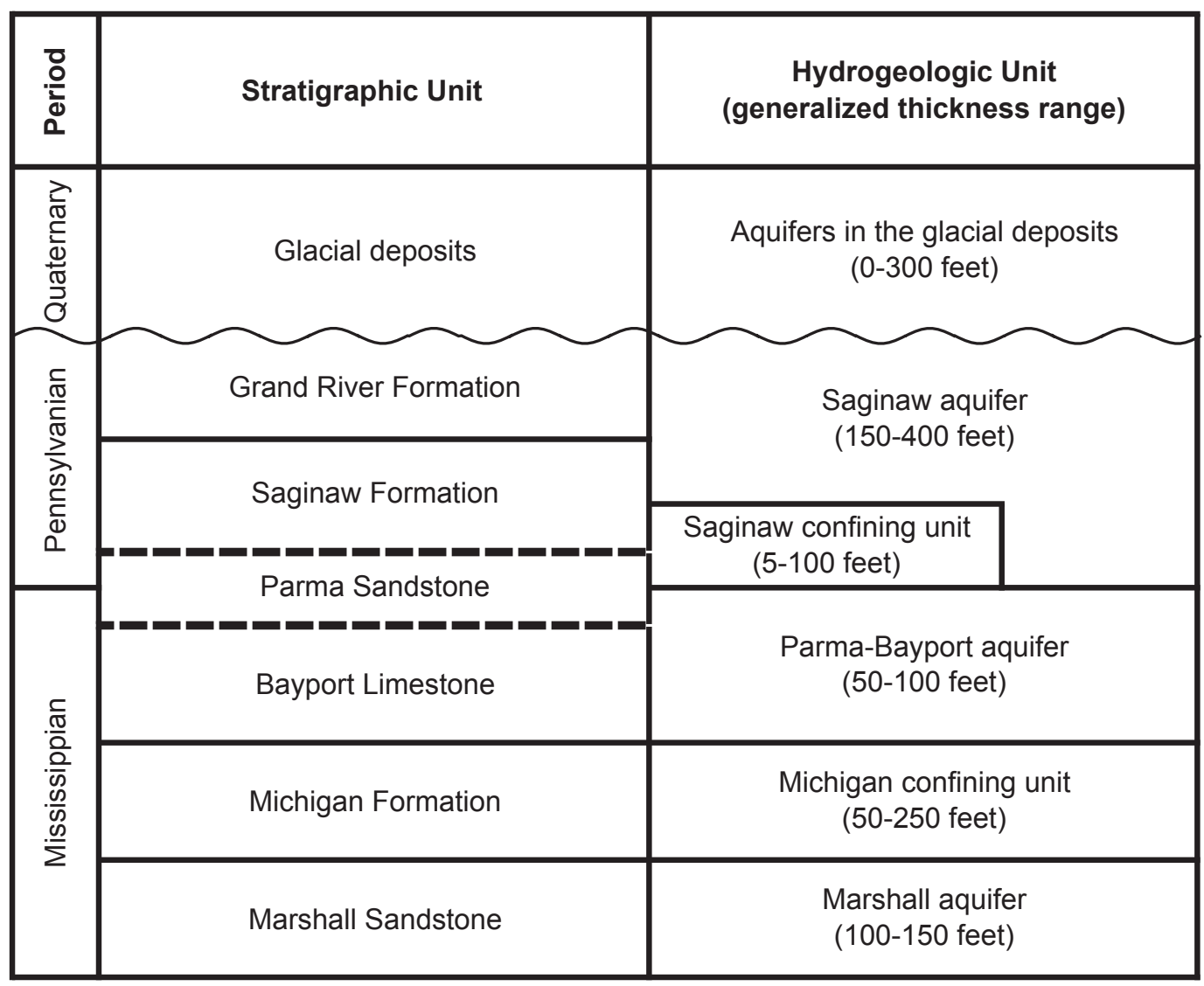

Figure 3. Stratigraphic nomenclature and hydrogeologic units, Tri-County region, Michigan. (Note: Figure denotes relation between units present in the Tri-County region and not the complete depositional history from the Mississippian through Quaternary periods. The Parma Sandstone is considered by some researchers to form the basal part of the Pennsylvanian Saginaw Formation. Other researchers have assigned the lower part of the Parma Sandstone to the late Mississippian. Dashed line indicates uncertainty in the placement of the Parma Sandstone into the Pennsylvanian or the Mississippian periods. The Parma Sandstone is hydraulically connected to the Bayport Limestone and these units together form the Parma-Bayport aquifer.)

study area. Glacial deposits are of three principal types: (1) a well-sorted mixture of silt, sand, and gravel, such as valley outwash, outwash plains, eskers, kames, and buried outwash, deposited by streams of meltwater draining from glaciers; (2) a layered sequence of silt, sand, and clay deposited in glacial lakes; and (3) an unsorted mixture of clay, silt, sand, gravel, and boulders, such as till, deposited directly from the melting ice (Vanlier and others, 1973). None of these types of deposits is regionally continuous (Mandle and Westjohn, 1989).

\section{Hydrogeologic Setting}

Glacial deposits form the uppermost aquifer in the TriCounty region. Groundwater flow in the glacial deposits is generally from south to north, away from topographic divides and toward surface-water bodies. Aquifers in the glacial deposits are composed primarily of coarse alluvial and outwash materials. Long, narrow ridges of sand and gravel, called eskers, are present in Ingham and Eaton Counties and in parts of Clinton County, primarily in the southeast. Esker deposits yield water to municipal wells in Williamston and, historically, yielded water in Mason. Buried outwash deposited by preceding glaciers was covered by layers of till deposited during a later glacial advance. The most extensive areas of buried outwash deposits are in the northern part of Ingham County, the northeastern part of Eaton County, and the southern part of Clinton County. These areas of buried outwash are a potential source of water to wells; however, most wells in these areas are completed in bedrock aquifers because of the better quality of water available at depth. Till is present over much of the region and is generally not a source of water to wells (Vanlier and others, 1973). Locally, the till may include thin beds of sand and gravel that are a source of water or may overlie bodies of sand and gravel that may yield moderate to large supplies of water (Vanlier and others, 1973). Lake plain deposits, consisting of beds of clay, silt, and sand deposited in glacial lakes, underlie parts of Clinton County; however, these deposits generally are thin and in most places are not sources of water to wells (Vanlier and others, 1973). The MDEQ 
Model Refinement and Simulation of Groundwater Flow in Clinton, Eaton, and Ingham Counties, Michigan

Public-Water-Supply database indicates ranges of transmissivity for the glacial deposits of 615 to $127,000 \mathrm{ft}^{2} / \mathrm{d}$ in Eaton County and 540 to $20,050 \mathrm{ft}^{2} / \mathrm{d}$ in Clinton County (Michigan Department of Environmental Quality, 2009).

The Saginaw aquifer is in the water-bearing sandstones in the Grand River and Saginaw Formations. The Saginaw aquifer can be thought of as an aquifer system consisting of three sandstone units separated by an upper, interbedded-series unit and a lower shale unit (David Westjohn, U.S. Geological Survey, oral commun., 2005). Division of the Saginaw aquifer into these units is uncertain in some areas because of incomplete or missing well-log data or heterogeneities within and varying thicknesses of these units in the formation. Most groundwater flow in the Saginaw aquifer is from south to north, although a small amount is toward local pumping centers (fig. 4). Flow across the eastern part of Ingham County, where the sandstone of the Saginaw Formation is very thin or absent, is minimal. The Saginaw aquifer is recharged principally by leakage from the glacial deposits primarily in areas where aquifers in the glacial deposits are in direct connection with the Saginaw aquifer, but also minimally through confining unit(s) consisting of a lower till unit in the glacial deposits and (or) an upper shale unit in the Saginaw Formation. Groundwater discharges locally from bedrock to the glacial deposits beneath valleys of major streams (Holtschlag and others, 1996). The Grand River and Saginaw Formations act as a single hydrologic unit, so the chemical characteristics of water in these formations are very similar. Nearly all wells tapping these formations yield water that is suited to household needs. The water is generally hard or very hard and contains iron, although in some localities the Saginaw Formation yields soft water (Vanlier and others, 1973).

Analyses of aquifer-test data indicate a wide range of transmissivities within the Saginaw aquifer. Wood (1969) reported that pumping tests indicated a relatively constant permeability of the sandstone in the Saginaw Formation of about $100 \mathrm{gal} / \mathrm{d} / \mathrm{ft}^{2}(13 \mathrm{ft} / \mathrm{d})$. The permeability of the shale is more variable, ranging from 0.01 to $1.0 \mathrm{gal} / \mathrm{d} / \mathrm{ft}^{2}(0.001$ to $0.13 \mathrm{ft} / \mathrm{d}$ ) (Wood, 1969). Transmissivities that range from 130 to $2,700 \mathrm{ft}^{2} / \mathrm{d}$ were reported for the Saginaw aquifer within the Tri-County region by Vanlier and Wheeler (1968). This range in transmissivities reflects variations in the total thickness of the sandstone beds and variations in the permeability of the sandstone. The MDEQ Public-Water-Supply database (that includes data from selected public-supply well locations) indicates ranges of transmissivity for the Saginaw aquifer of 840 to $3,240 \mathrm{ft}^{2} / \mathrm{d}$ in Eaton County and 450 to $3,890 \mathrm{ft}^{2} / \mathrm{d}$ in Clinton County (Michigan Department of Environmental Quality, 2009). Measured porosities and vertical hydraulic conductivities range from 4 to 34 percent and 0.0001 to $55 \mathrm{ft} / \mathrm{d}$, respectively (Westjohn and Weaver, 1996).

\section{Groundwater Withdrawals}

Groundwater is the principal source of water supply for the Tri-County region. The majority of communities rely on groundwater from the Saginaw aquifer; however, groundwater from aquifers in the glacial deposits is important in some areas. The communities of Lansing, Webberville, Ovid, and Fowler initially withdrew water from the glacial deposits. These communities later added wells drilled into the Saginaw aquifer. According to data for 2005, Eaton Rapids, Elsie, Fowler, Lansing, Mason, Williamston, and St. Johns use combinations of wells completed in aquifers in the glacial deposits and the Saginaw aquifer; the communities of Dewitt, East Lansing, Grand Ledge, Leslie, Ovid, Potterville, Webberville, and Westphalia withdraw water from the Saginaw aquifer. The communities of Charlotte, Maple Rapids, Sunfield, and Vermontville depend on groundwater from aquifers in the glacial deposits. A small amount of groundwater is withdrawn from the Marshall aquifer in southwestern Eaton County by the communities of Bellevue and Olivet.

For communities within the study area, data on withdrawals from 1970 to 1990 were primarily based on records furnished by municipal suppliers, published in annual data reports of the USGS (Huffman and Thompson, 1971, 1973; Huffman, 1974a, 1974b, 1975, 1976, 1977, 1979a, 1979b; 1980; 1981; 1982; 1983; 1984; 1985; 1986; 1988; Huffman and Whited, 1988; 1989; 1991; 1993), or included in previous studies of the area. Additional data are available in a report by Baltusis and others (1992), who summarized sources and annual withdrawals of groundwater for communities in the Lower Peninsula of Michigan. In the Tri-County region, groundwater withdrawals increased steadily from early 1900 to the late 1970s (fig. 5). Withdrawals were more constant from the late 1970s to 2004 and increased in 2005, with most of this increase likely attributed to expansion of municipal service areas. Before 1970, withdrawals were concentrated in the north Lansing area; after 1970, withdrawals were divided among wells located over a larger area, with more wells installed primarily in the south (figs. 2 and 6).

\section{Water Levels and Streamflow}

Water-level and streamflow data are both needed to assist with model calibration to indicate how well the model represents the actual groundwater-flow system (fig. 7 and table 1). Groundwater levels in wells screened across the water table indicate the position of the water table; wells tapping deeper parts of an aquifer indicate the composite hydraulic head over the screened or open interval. Water-level data are available from well logs from the MDEQ Wellogic database and from observation wells in the Tri-County region. Within the Tri-County region, water-level data are available from almost 23,300 well logs with well installation dates ranging from 1912 to 2005. Data from about 11,900 of these wells, along with data from 34 observation wells that were measured for 


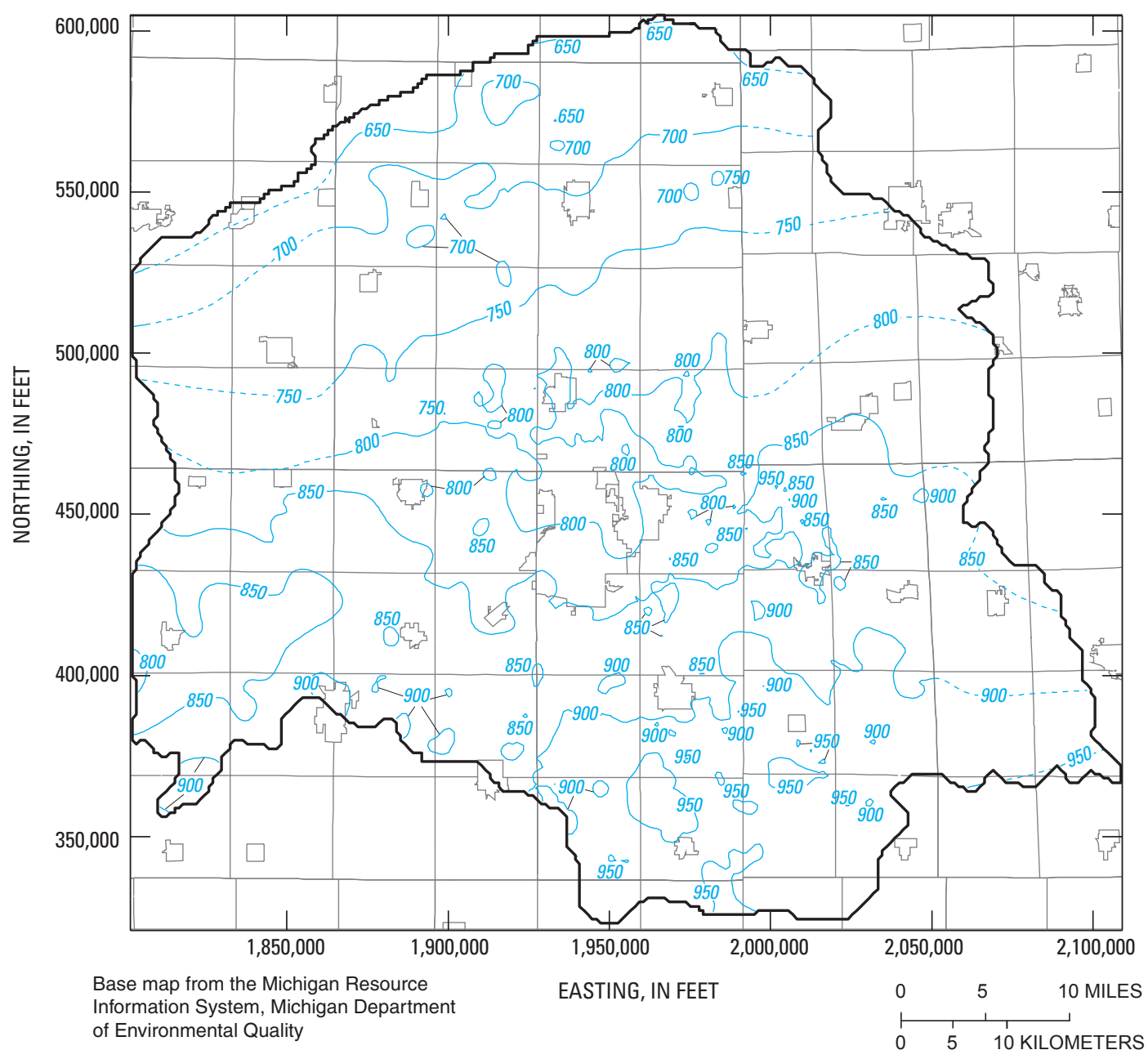

EXPLANATION

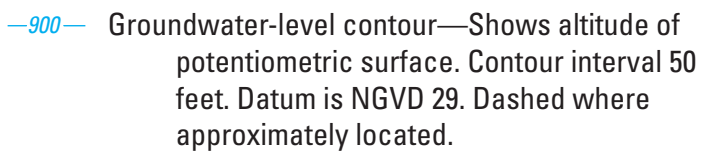

Model area

Figure 4. Groundwater levels in the Saginaw aquifer in the model area, Tri-County region, Michigan. (Data from Holtschlag and others, 1996.)

various intervals during 1930 to 2005 , were used during calibration of the transient model. The observation-well data are thought to be more accurate; however, many of these observation wells are in the Lansing area and are affected by pumping. Therefore, inclusion of data from well logs serves as additional control on simulation results by providing water-level information in areas not affected by pumping. Data compiled during development of the 1996 model also were used during calibration of the 2009 steady-state model to allow comparison between the original and refined models. These 1996 data consisted of 2,932 water-level measurements from well logs, 805 groundwater levels from water-surface altitudes posted for lakes and topographic contour crossings of perennial streams, and 130 observation-well measurements. Measurements in the upper layer were not restricted to a particular time period; however, measurements in the lower layer were restricted to the period 1984-92 because of local trends in the historical groundwater-head data associated with changes in pumping conditions (Holtschlag and others, 1996).

Streamflow data are available from continuous-record gaging stations for which daily mean streamflows are computed for 1 or more years. Streamflow can be subdivided into direct-runoff and base-flow components. Direct runoff is associated with the component of precipitation that exceeds the infiltration capacity of the soil and flows overland directly into streams. Base flow is associated with the component of 


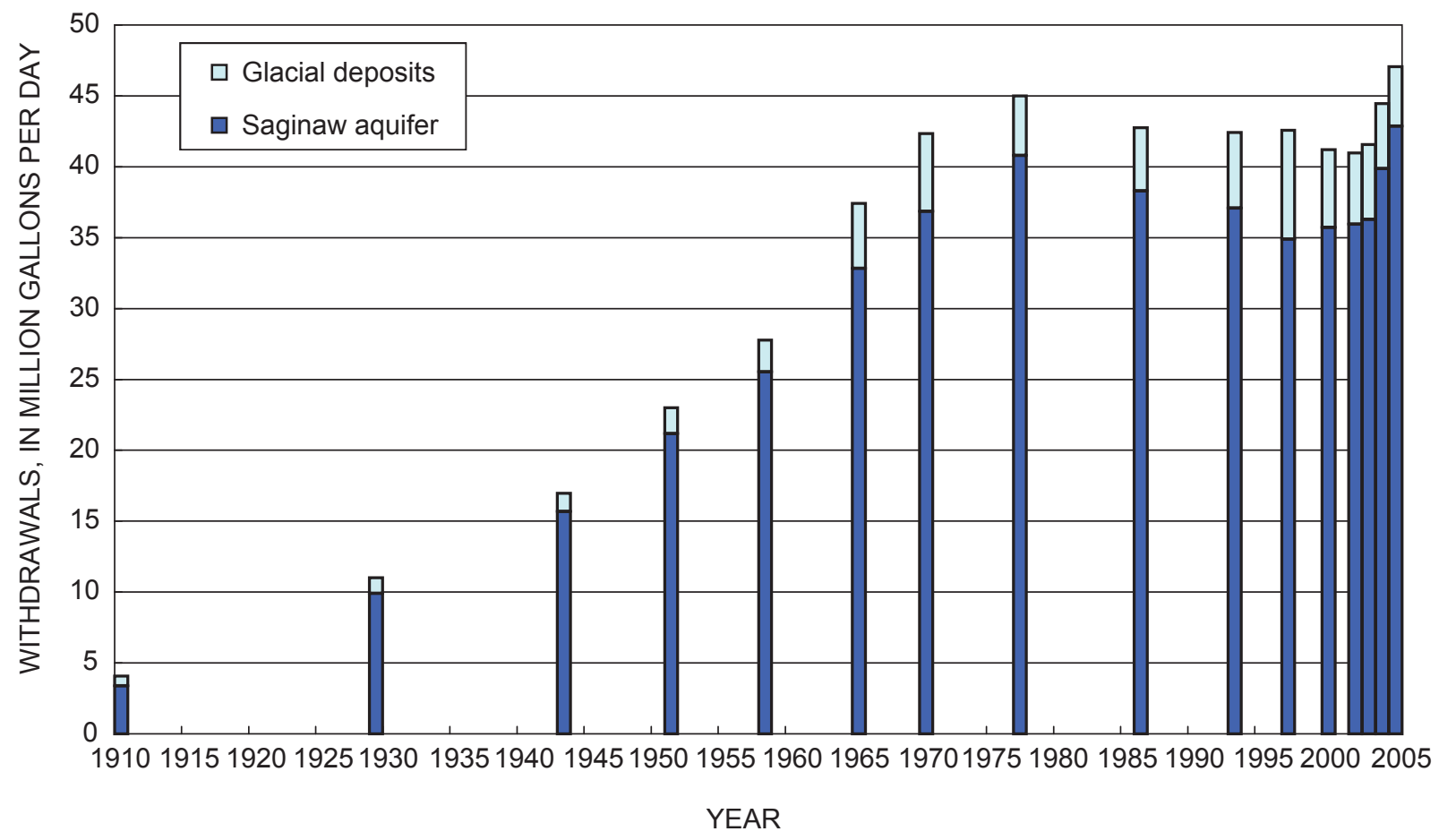

Figure 5. Groundwater withdrawals from the Saginaw aquifer and glacial deposits, Tri-County region, 1910-2005. (Data from William Maier, Lansing Board of Water and Light, written commun.; Douglas MacDonald, Michigan State University, written commun.; Michael St. Bernard, East Lansing and Meridian Township Water Authority, written commun.; Huffman and Thompson, 1971, 1973; Huffman, 1974a, 1974b, 1975, 1976, 1977, 1979a, 1979b, 1980; 1981, 1982, 1983, 1984, 1985, 1986, 1988; Huffman and Whited, 1988, 1989, 1991, 1993; and Baltusis and others, 1992.)

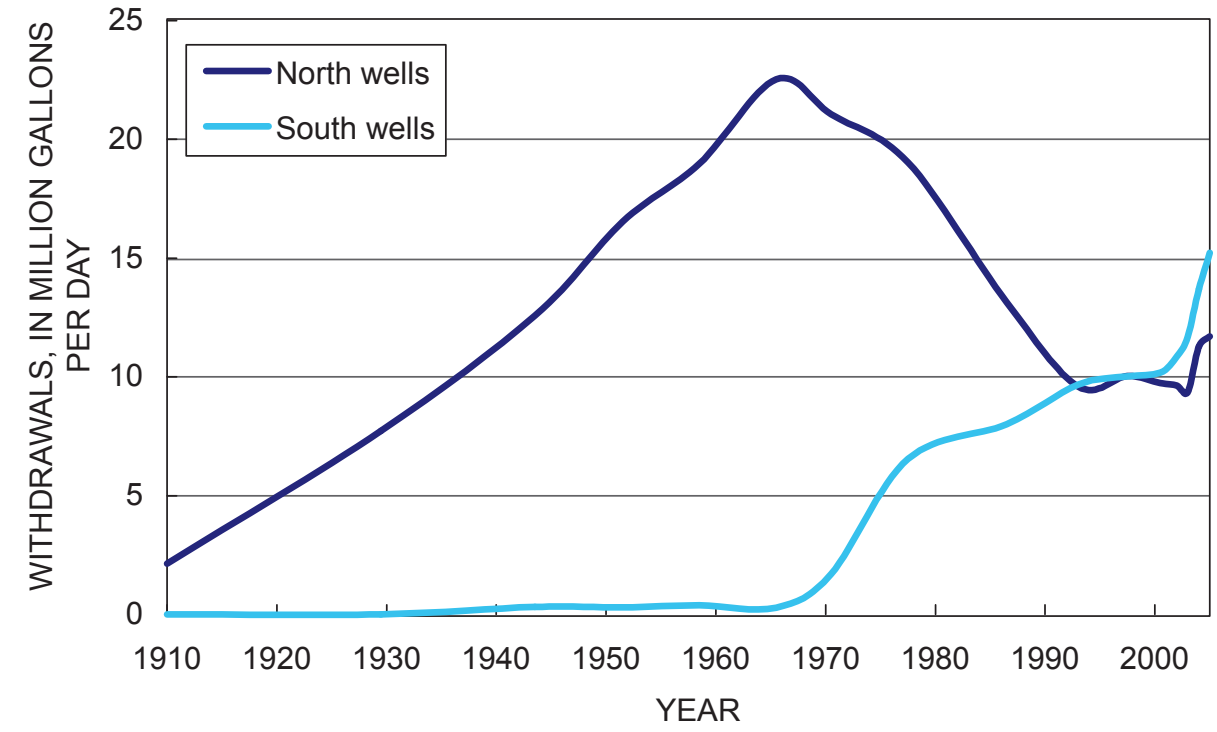

Figure 6. Comparison of groundwater withdrawals from the North and South Lansing areas, Michigan, 1915-2005. (See figure 2 for the locations of these areas.) 


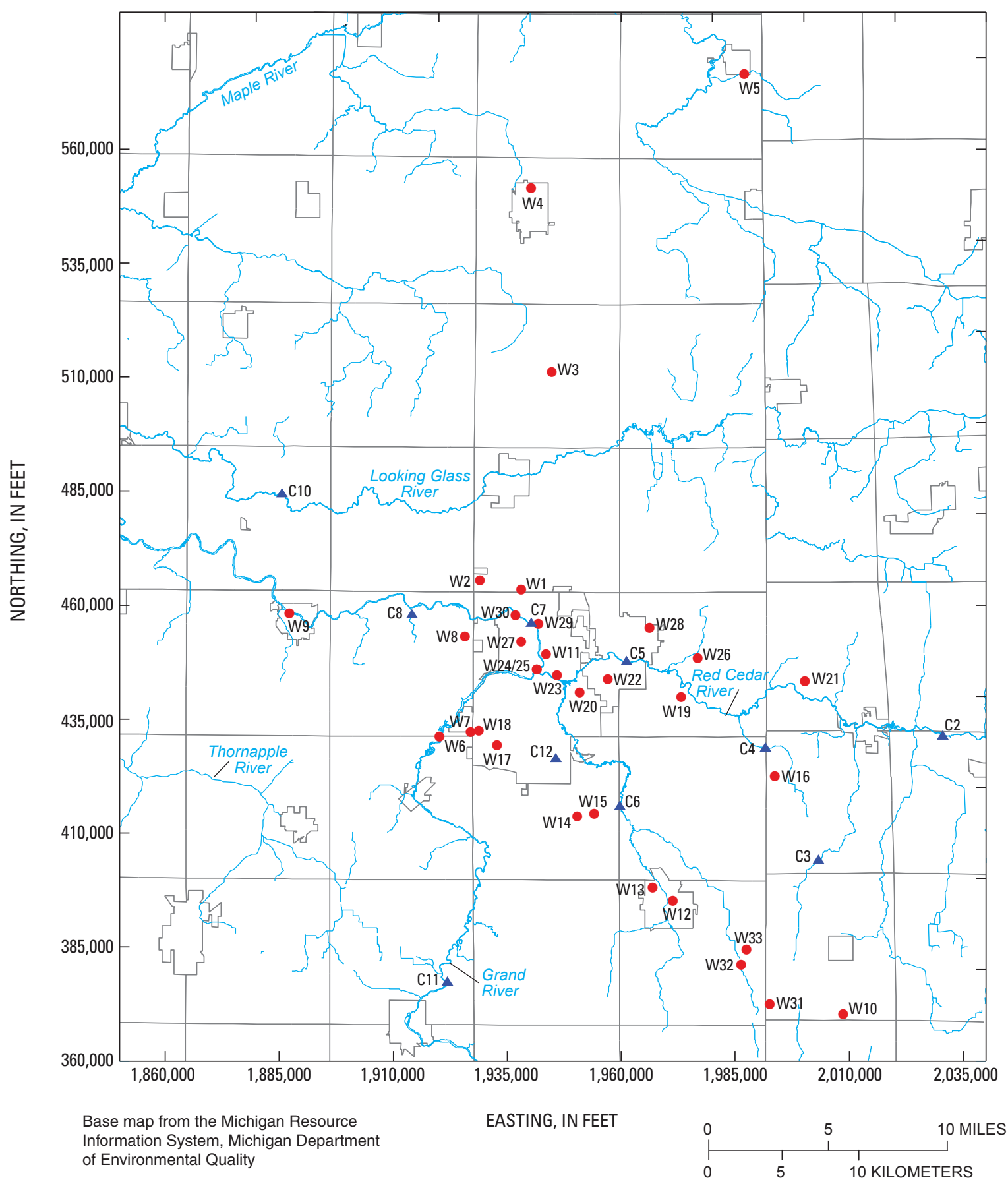

EXPLANATION

A C4 Streamgaging-station location and identifier

- W7 Observation-well location and identifier

Figure 7. USGS streamgaging stations and observation wells, Tri-County region, Michigan. 
Table 1. USGS streamgaging stations and observation wells in the Tri-County region, Michigan.

[Locations of stations and wells are shown on figures 7 and 13.]

\begin{tabular}{|c|c|c|c|c|}
\hline \multicolumn{5}{|c|}{ Streamgaging stations } \\
\hline $\begin{array}{l}\text { Map } \\
\text { index }\end{array}$ & $\begin{array}{c}\text { USGS gaging-station } \\
\text { number }\end{array}$ & Station name & $\begin{array}{l}\text { Drainage area } \\
\qquad\left(\mathrm{mi}^{2}\right)\end{array}$ & Period of record \\
\hline $\mathrm{C} 1$ & 04110000 & Orchard Creek at state HWY 106 near Munith & 49 & $1944-56$ \\
\hline $\mathrm{C} 2$ & 04111379 & Red Cedar River near Williamston & 163 & $1975-89,2001-7$ \\
\hline $\mathrm{C} 3$ & 04111500 & Deer Creek near Dansville & 16.3 & 1954-2007 \\
\hline $\mathrm{C} 4$ & 04112000 & Sloan Creek near Williamston & 9.34 & $1954-2007$ \\
\hline $\mathrm{C} 5$ & 04112500 & Red Cedar River at East Lansing & 355 & $1903,1931-2007$ \\
\hline C6 & 04112850 & Sycamore Creek near Holt & 80.6 & 1975-80, 1989-90, 1994-97 \\
\hline $\mathrm{C} 7$ & 04113000 & Grand River at Lansing & 1,230 & $1901-6,1934-2007$ \\
\hline $\mathrm{C} 8$ & 04113097 & Carrier Creek near Lansing & 12.1 & $1975-80$ \\
\hline C9 & 04114000 & Grand River at Portland & 1385 & $1952-82,1988-2007$ \\
\hline $\mathrm{C} 10$ & 04114498 & Looking Glass River near Eagle & 280 & $1944-96,2001-7$ \\
\hline $\mathrm{C} 11$ & 04111000 & Grand River at Eaton Rapids & 661 & $1950-82,1995-2007$ \\
\hline $\mathrm{C} 12$ & 04112904 & Mud Lake Drain at Lansing & 4.25 & $1975-76$ \\
\hline
\end{tabular}

\begin{tabular}{|c|c|c|c|c|}
\hline \multicolumn{5}{|c|}{ Observation wells } \\
\hline $\begin{array}{c}\text { Map } \\
\text { index }\end{array}$ & Well number & Well name & Aquifer & Period of observations \\
\hline W1 & 424618084340401 & Quarantine Farm & Saginaw & $1944-93,2005-6$ \\
\hline W2 & 424637084360601 & Capital City Airport & Saginaw & $1960-88$ \\
\hline W3 & 425408084323601 & US-27 & Glacial & $1948-95,2000,2005-6$ \\
\hline W4 & 430047084333801 & St. Johns & Saginaw & $1964-84$ \\
\hline W5 & 430454084230901 & Village of Elsie & Saginaw & $1947-72$ \\
\hline W6 & 424058084380301 & Steifel & Glacial & 1965-2001, 2003, 2005-6 \\
\hline W7 & 424108084363201 & Roscommon St. & Saginaw & $1993-95,2005-06$ \\
\hline W8 & 424435084365001 & Robins Road & Saginaw & 1954-2005 \\
\hline W9 & 424524084452501 & Grand Ledge & Saginaw & $1948-74$ \\
\hline W10 & 423058084181801 & Dansville State Game Area & Glacial & $1963,1973-76,1988-92,2005-6$ \\
\hline W11 & 423127084321901 & Cedar Well & Saginaw & $1945-54,1960-2007$ \\
\hline W12 & 423503084263701 & Mason Old \#2 & Saginaw & $1948-74$ \\
\hline W13 & 423532084274001 & Kerns Rd & Saginaw & $1965-91,2003,2005-6$ \\
\hline W14 & 423805084311801 & Holt & Saginaw & $1982-2007$ \\
\hline W15 & 423812084302801 & Delhi Twp & Saginaw & $1961-66$ \\
\hline W16 & 423933084213801 & Lotte & Saginaw & 1964-92 \\
\hline W17 & 424040084351401 & Davis Park & Saginaw & $1991-94,2005-6$ \\
\hline W18 & 424111084360701 & Maybel & Saginaw & $1945-93,2005-6$ \\
\hline W19 & 424225084261401 & Okemos & Saginaw & $1976-93,2005-6$ \\
\hline W20 & 424235084311201 & Fenner Arboretum & Saginaw & 1968-82, 1991-2007 \\
\hline W21 & 424300084201001 & Sherwood Rd & Saginaw & $1963-80,2005-6$ \\
\hline W22 & 424303084295001 & Spartan village & Saginaw & 1946-84, 1986-92 \\
\hline W23 & 424312084321801 & Pennsylvania (P-5) & Saginaw & $1931-95,2005-6$ \\
\hline
\end{tabular}


Table 1. USGS streamgaging stations and observation wells in the Tri-County region, Michigan.—Continued

[Locations of stations and wells are shown on figures 7 and 13.]

\begin{tabular}{|c|c|c|c|c|}
\hline \multicolumn{5}{|c|}{ Observation wells-Continued } \\
\hline $\begin{array}{c}\text { Map } \\
\text { index }\end{array}$ & Well number & Well name & Aquifer & Period of observations \\
\hline W24 & 424324084331801 & Scott Park & Saginaw & $1971-75,1980-88,1993-95$ \\
\hline W25 & 424324084331802 & Townsend & Saginaw & 1929-71 \\
\hline W26 & 424349084252501 & Meridian Twp. & Saginaw & $1968-92$ \\
\hline W27 & 424424084340301 & Logan & Saginaw & 1960-2007 \\
\hline W28 & 424455084274601 & Marble School & Saginaw & $1953-80,2005$ \\
\hline W29 & 424502084331301 & Seymour & Saginaw & 1961-80, 1986-2007 \\
\hline W30 & 424521084342101 & Muskegon Street & Saginaw & 1991-94 \\
\hline W31 & 423120084215301 & Kelly Rd & Saginaw & 2003 \\
\hline W32 & 423245084231601 & Hawley Rd & Saginaw & 2003 \\
\hline W33 & 423318084230201 & Dexter Trail & Saginaw & 2003 \\
\hline
\end{tabular}

precipitation that infiltrates the soil and percolates below the plant-rooting depth, where it can enter (recharge) the groundwater system. Base-flow characteristics of streams were used to help determine the amount of precipitation that recharges groundwater in the Tri-County region. In this study, streamflow partitioning (Rutledge, 1993) was used to estimate base flow to streams for the transient calibration by use of data from 10 continuous-record gaging stations over each period of record. Similar to the water-level data, streamflow data determined for the 1996 model were used during calibration of the 2009 steady-state model. The 1996 data consisted of baseflow estimates at 10 continuous-record gaging stations and 25 partial-record gaging stations.

\section{Groundwater-Flow Models}

The U.S. Geological Survey modular three-dimensional finite-difference numerical groundwater-flow model MODFLOW-2000 (Harbaugh and others, 2000) was used to simulate groundwater flow in the Tri-County region. MODFLOW-2000 allows the simulation of steady-state or transient groundwater flow in three dimensions with leakage between model layers. In addition, MODFLOW-2000 contains processes that allow inclusion of observations and comparison of measured and calculated values, development of parameter sensitivities, and estimation of parameter values (Hill and others, 2000). Simulation of groundwater flow is made possible by first developing a conceptual model of the flow system and then developing a numerical model that is consistent with the conceptual model. Results of simulations with the models described in this report numerically illustrate the potential effects of natural and anthropogenic influences on water levels and flows and evaluate various pumping scenarios under different management constraints. Model refinement and the calibration of the steady-state and transient models are described below.

\section{Conceptual Model}

The conceptual model describes groundwater flow within the Tri-County region and surrounding areas and includes delineation of aquifers, confining units, and groundwater-flowsystem boundaries. Groundwater flow in the glacial deposits is unconfined and generally from south to north, away from topographic divides and towards surface-water bodies. Thus, surface-water drainage divides are assumed to be groundwater-flow divides for groundwater in the glacial deposits.

Most groundwater flow in the Saginaw aquifer is from south to north, although a small amount is toward local pumping centers. Flow across the east and west model area, where the sandstones of the Saginaw Formation are very thin or absent, is minimal. Generally, groundwater flows toward the Maple River, which forms the northern hydrologic boundary of the model area; locally, some groundwater flows toward the southern hydrologic boundary. Flow between aquifers in the glacial deposits and the Saginaw Formation is limited where confining unit(s) consisting of a lower till unit in the glacial deposits and (or) an upper shale unit in the Saginaw Formation are present. Groundwater also discharges locally from bedrock to the glacial deposits in the valleys of major streams. Local and regionally extensive confining materials limit the vertical movement of water between sandstone units in some areas within the Saginaw Formation. Groundwater is confined in the Saginaw aquifer except for a small area near Grand Ledge where the Saginaw Formation outcrops along part of the Grand River. For the purposes of this model, the bottom of the Saginaw aquifer is assumed to be impermeable. 


\section{Numerical Models}

The model area consists of Clinton, Eaton, and Ingham Counties along with parts of Ionia, Shiawassee, Jackson, and Livingston Counties (fig. 8). This large area is simulated to minimize boundary effects on model-calculated heads, flow rates, and flow directions in the interior part of the model by allowing natural physical and hydrologic boundaries to be used as much as possible. The placement of boundaries distant from the nine-township area also allows for development of predictive simulations within the center of the TriCounty area to investigate water availability and the effects of water withdrawals.

Model development includes the specification of grid characteristics, boundary conditions, and input variables, such as hydraulic properties of the aquifers and pumping rates. Model calibration then proceeds with the comparison of model-simulated heads (water levels) and streamflows with measured values of heads and streamflows for steadystate or transient conditions. Under the steady-state assumption there is no change in groundwater storage during the simulated period; that is, all water entering the model area through the boundaries or as recharge is assumed to leave the model area through the boundaries, rivers, or wells. Groundwater withdrawals and recharge rates remain constant during the steady-state simulation. During a transient simulation, water is released from or taken into aquifer storage. Heads change with time as a result of this transfer of water. When the transfer to and from storage stops, the groundwater-flow system reaches steady state and heads stabilize (Anderson and Woessner, 1992). Groundwater withdrawals and recharge rates can change during the transient simulation. Steady-state and transient models are both useful for simulating the groundwater-flow system. Average conditions are used in steady-state models to predict long-term average heads and flows. Transient models can be used to help predict responses to both short-term and long-term changes in stresses. For this study, the groundwater-flow model was calibrated to both steadystate and transient conditions in order to simulate the response of the groundwater-flow system under different conditions.

The refined steady-state model was developed to represent conditions in the Tri-County area under average 1991-95 pumping conditions because water-level and streamflow data both were available for calibration and the model had previously been calibrated to these conditions. With the relative constancy of withdrawals since the early 1970s (fig. 5) and the constancy of average precipitation rates, the assumption of steady-state conditions during 1991-95 is believed to be appropriate, and measured heads and streamflows used for calibration are assumed to represent long-term average conditions. Simulation results from the 2009 model were compared to simulation results from the 1996 model to check that the model refinements had not changed the representation of the groundwater-flow conditions in the area.

Transient models were developed to investigate the groundwater-flow-system response to changes in recharge and withdrawal rates from the early 1900s to 2005 and to investigate various water-supply management scenarios. Available data on groundwater withdrawals and observations for each time period were averaged to be representative of average recharge years. Groundwater withdrawal rates varied over the transient simulations on the basis of available recorded and estimated data. Historic precipitation data were used to assist with determining variations in groundwater recharge rates. Available data for water levels and streamflow were compared to simulated values for each model stress period. The following sections describe details of model development, calibration, and results of simulations with the steady-state and transient models.

\section{Spatial and Temporal Discretization}

The model area covers about 3,500 $\mathrm{mi}^{2}$; about 62 percent of this area consists of active model cells. The area is approximately $61 \mathrm{mi}$ long (north-south) and $58 \mathrm{mi}$ wide (east-west). Part of the southern model boundary was extended beyond the 1996 model extent to permit model simulations in the Eaton Rapids and Eaton Rapids Township area (fig. 8). The model consists of 338 rows and 307 columns of grid cells that vary in size. Smaller grid cells in the central part of the model permit representation of smaller scale flows and pumping where the majority of groundwater withdrawals occur. In the central part of the model area, each cell is approximately 660 by $660 \mathrm{ft}$. Cell spacing increases outward from the central part of the model area in each direction by a factor of 1.2 to a maximum grid spacing of about $1,330 \mathrm{ft}$. Each grid cell is assigned the average aquifer properties for the volume of aquifer represented by the cell; variations in properties within a grid cell cannot be represented. Glacial deposits are known to vary considerably in lithology and thickness over short distances (tens to hundreds of feet). This variability makes exact representation of the detailed hydrogeology difficult in a regional-scale model. Therefore, hydraulic properties of the units within the model layers are generalized to represent the regional groundwater-flow system.

Land-surface elevation data for most of the model area are available from USGS 30-m datasets with a vertical resolution of 5-10 ft. This information was used to construct model layers by subtracting depths of estimated layers (determined from well-log data) from the land-surface elevation. The initial estimates of water-level elevations also were developed by subtracting the depth to water recorded on well logs from the land-surface elevations. In areas where the geologic materials composing a layer are absent, the layer was assigned a minimal thickness and the hydraulic properties of the overlying layer. Additional delineation of layer surfaces in areas of sparse data was accomplished by interpolating from known nearby points. The lowermost model layer (layer 10) represents the material underlying the Saginaw aquifer and was included because well logs indicate that some wells may be completed below the bottom of the Saginaw aquifer. This layer was assigned a constant thickness of $50 \mathrm{ft}$ over the whole model area. 

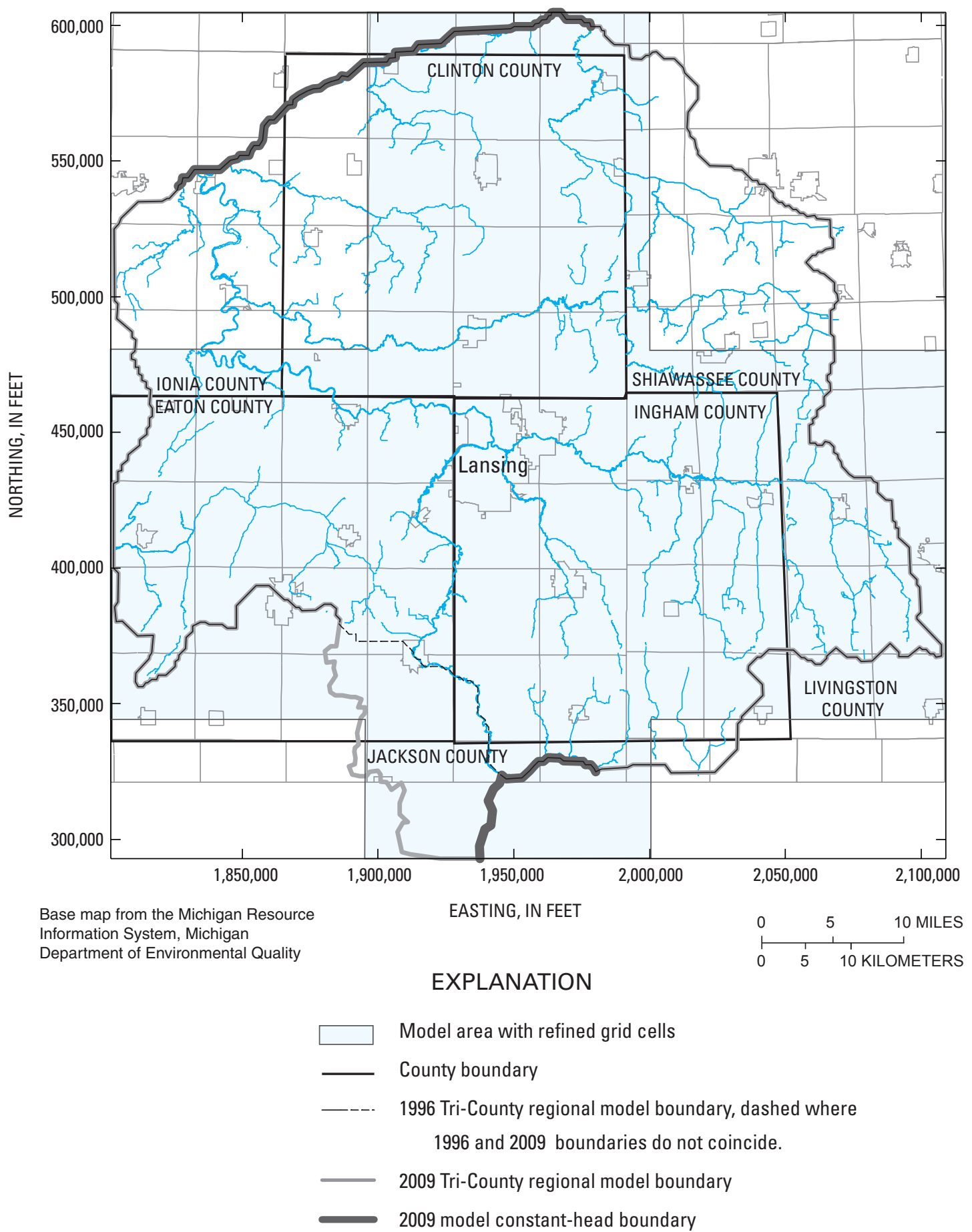

Figure 8. Model boundary and refined grid area, Tri-County region, Michigan.

Transient calibration requires specifying how the simulation period will be divided into stress periods and the number of time steps within each stress period. The stress periods and time steps specify the length of time used in determining the groundwater-flow solution and times when selected stresses, such as groundwater withdrawals and recharge rates, can change during the simulation. The use of stress periods offers the option of changing some of the parameters or stresses while the simulation is in progress (Anderson and Woessner,
1992). The initial stress period for the transient model was steady state and was specified to simulate predevelopment conditions, with recharge rates equal to those developed for the 1996 model and with no groundwater withdrawals. The subsequent 16 stress periods were based on available pumping data and analysis of observation-well water-level data. Stressperiod length varied from 20 years to 1 year, with earlier stress periods generally covering the longer time periods because little water-level data are available for the early 1900s and 
stresses on the system were mild. Shorter stress periods were selected for the 1960s and early 1970s because of more concentrated pumping and larger water-level drawdowns during this interval. The initial transient stress period covers pre-1920 conditions, with the remaining 15 stress periods spanning the remaining time. The last stress period represented 2005 conditions (table 2). After calibration, additional stress periods were added to the transient model to simulate pumping conditions that vary by month. The additional stress periods cover 8 years, with each year represented by 12 (monthly) stress periods. Pumping conditions vary, with the first 6 years representing average recent pumping conditions (as specified by several water-supply systems in the nine-township area) and the next 2 years (years 7 and 8 ) representing varied withdrawal and (or) recharge rates. The new transient model (with a total of 113 stress periods) was run under the same conditions for 6 years, until the change in storage during the last year became minimal. Changes in water levels and flows could then be attributed to the modeled changes in recharge or withdrawal rates and not to changes in the amount of water in storage.

Selection of each time step is important because the values of time discretization can affect the accuracy of the numerical calculations. Ideally, use of small nodal spacing and small time steps is desirable so that the numerical representation approximates the groundwater-flow equation as closely as possible (Anderson and Woessner, 1992). Time steps can be increased as the simulation progresses. The groundwaterflow solution is sensitive to rapidly fluctuating water levels caused by introducing a stress; thus, small time steps are often used at the beginning of each new stress period to allow the early response of the system to be accurately simulated. Even with a large time step, the solution becomes more accurate as steady state is reached. As a rule of thumb, the solution should proceed through five time steps, during which there are no appreciable changes in values of sources and sinks or boundary conditions, before the solution is considered accurate (Marsily, 1986). The number of time steps within each stress period varied from 12 to 40 . A multiplier of 1.5 on the length of each time step within a stress period was used to allow the initial time steps in each stress period to be relatively short and later time steps to be relatively long. For comparison of model results to observations, the groundwater-flow solution for the last time step of each stress period was used. For the transient model representing monthly time scales, the number of time steps during the initial 17 stress periods was reduced to permit faster processing time. The number of time steps within the first 16 transient stress periods varied from 12 to 20; the number of time steps in each subsequent stress period varied from 14 time steps for each month to 34 for the final 3 months.

Table 2. Transient model details for model representing early 1900s to 2005, Tri-County region, Michigan.

[Mgal/d, million gallons per day]

\begin{tabular}{rllcccc}
\hline $\begin{array}{c}\text { Stress } \\
\text { period }\end{array}$ & Stress period type & $\begin{array}{c}\text { Time interval } \\
\text { represented by } \\
\text { stress period }\end{array}$ & $\begin{array}{c}\text { Stress period } \\
\text { length } \\
\text { (days) }\end{array}$ & $\begin{array}{c}\text { Simulated } \\
\text { pumping } \\
\text { (Mgal/d) }\end{array}$ & $\begin{array}{c}\text { Initial } \\
\text { recharge } \\
\text { multiplier }\end{array}$ & $\begin{array}{c}\text { Final } \\
\text { recharge } \\
\text { multiplier }\end{array}$ \\
\hline 1 & Steady-state & Predevelopment & - & 0 & 1 & 1 \\
2 & Transient & Pre-1920 & 3,650 & 3.6 & 1 & 1 \\
3 & Transient & $1921-38$ & 6,570 & 10.5 & 1.04 & 1 \\
4 & Transient & $1939-48$ & 3,650 & 16.4 & 1.06 & 1.06 \\
5 & Transient & $1949-54$ & 2,190 & 22.3 & 1.04 & 1.09 \\
6 & Transient & $1955-62$ & 2,920 & 26.7 & .98 & .94 \\
7 & Transient & $1963-68$ & 2,190 & 36.0 & .98 & .91 \\
8 & Transient & $1969-72$ & 1,460 & 40.5 & 1.08 & 1.15 \\
9 & Transient & $1973-82$ & 3,650 & 43.6 & 1.07 & 1.12 \\
10 & Transient & $1983-90$ & 2,920 & 41.7 & 1.15 & 1.22 \\
11 & Transient & $1991-95$ & 1,825 & 42.6 & 1.16 & 1.22 \\
12 & Transient & $1996-99$ & 1,460 & 41.6 & 1.03 & 1.03 \\
13 & Transient & $2000-2001$ & 730 & 40.2 & 1.2 & 1.2 \\
14 & Transient & 2002 & 365 & 40.0 & .83 & .83 \\
15 & Transient & 2003 & 365 & 40.5 & .94 & .87 \\
16 & Transient & 2004 & 365 & 43.4 & 1.16 & 1.22 \\
17 & Transient & 2005 & 365 & 46.1 & 1.08 & 1.08 \\
\hline
\end{tabular}




\section{Model Refinement}

In 1997, the 1996 regional model was refined to better represent flow within the nine-township area surrounding Lansing (Luukkonen and others, 1997a, b) (fig. 2). The uniform cell size in the 1996 model was modified to a variably-spaced grid, and simulated pumping rates were updated to reflect 1995 and 1997 pumping conditions. In 2003, the model was further refined to better represent flow within the Mason and Vevay Township area (Luukkonen and Simard, 2004). The hydraulic characteristics of the glacial deposits and the Saginaw aquifer were modified to better represent local conditions. The grid spacing was also modified in the Vevay Township area, and groundwater withdrawal rates by the city of Mason's production wells were updated to reflect average rates representative of mid-May 2003 pumping conditions. In the 2003 model, groundwater-recharge rates were not changed from the values used in the 1996 and 1997 regional models.

For the current study to develop the 2009 model, the 2003 model was further refined to allow simulation of scenarios that would most benefit water-resources managers and improve representation of the groundwater-flow system in the Tri-County region. These refinements included: (1) adjustments to the estimated regional groundwater recharge rates to account for temporal and spatial differences in local areas, (2) adjustments to the representation and hydraulic characteristics of the glacial deposits and Saginaw Formation, (3) representation of the system under steady-state and transient conditions, and (4) updates to groundwater withdrawal rates to reflect changes through time from the early 1900s to 2005 .

\section{Recharge Distribution}

Precipitation is the ultimate source of groundwater and surface-water resources in the Tri-County region. In the earlier models, the spatial distribution of recharge was based on an analysis relating base-flow characteristics of streams to land use and basin characteristics (Holtschlag, 1994). On the basis of the 1994 study, the minimum average annual recharge in the Tri-County region is $4.4 \mathrm{in} / \mathrm{yr}$, and the maximum is $16.5 \mathrm{in} / \mathrm{yr}$; the spatial average groundwater recharge rate is $6.7 \mathrm{in} / \mathrm{yr}$. This estimate of recharge was used in the 2009 steady-state model to facilitate comparison between the 1996 and refined 2009 model simulation results.

Temporal changes in recharge were determined for use in the transient models. Over the region, mean precipitation ranges from a maximum of about $32 \mathrm{in} / \mathrm{yr}$ in the southwest to about $30 \mathrm{in} / \mathrm{yr}$ elsewhere (Eichenlaub and others, 1990, p. 90). Historical precipitation data were collected for nine stations with data ranging from 1931 to 2005 . The lowest annual average precipitation amounts of less than $24 \mathrm{in} / \mathrm{yr}$ were in 1953 , 1958, and 1962-63 (fig. 9). Highest annual average precipitation amounts of greater than $39 \mathrm{in} / \mathrm{yr}$ were in 1942, 1975, and 1985. In this study, groundwater recharge is assumed to be some percentage of precipitation and to vary with annual precipitation amounts. Average recharge for the regional model area is less than precipitation; however, local recharge rates may approach, exceed, or be appreciably less than the average precipitation rate. Because of a lack of site-specific information on local or regional groundwater recharge rates, recharge for model simulations is assumed to vary temporally on the basis of the observed variations in precipitation rates; specifically, on the percentage change from the average precipitation rate of $30 \mathrm{in} / \mathrm{yr}$. For monthly intervals, estimated recharge was assumed to vary on the basis of calculated average base-flow values because this produced the best match between simulated and observed values. This assumption allows for better representation of actual groundwater recharge rates than would be possible by using the average monthly variation in precipitation because evapotranspiration rates are higher during the spring and summer, thus reducing the amount of precipitation available to recharge the groundwater system. However, this approach is based on the assumption that there is no lag between the timing of recharge and the timing of discharge into streams. Because of the generally better match between simulated and observed streamflows using variations in base-flow values than was achieved using variations in precipitation, this approach is believed to be appropriate for the monthly time scales used for the simulation. Over smaller time scales, the difference in timing between recharge and discharge to streams would likely become more significant.

\section{Glacial Aquifer Discretization}

For the 2009 model, the glacial aquifer materials were subdivided to better represent flow through the glacial deposits in the Tri-County region. Well logs from the Wellogic database were analyzed to determine the thickness and extent of glacial aquifer units. Owing to the variability of the glacial materials, regional units with similar hydraulic properties could not be determined. Therefore, three units were determined to represent the glacial materials. The uppermost glacial unit (layer 1) ranges in thickness from less than $1 \mathrm{ft}$ to $284 \mathrm{ft}$ and was made thickest for deposits adjacent to rivers to minimize problems associated with model convergence of calculated water levels. The remaining glacial materials were subdivided equally to create layers 2 and 3, each of which ranges in thickness from less than $1 \mathrm{ft}$ to $83 \mathrm{ft}$.

\section{Saginaw Formation Discretization}

For the 2009 model, the Saginaw Formation also was subdivided into multiple units to (1) better represent flow within the aquifer; (2) permit more detailed representation of the individual production-well characteristics, such as the elevations of the open intervals, and (3) allow for scenarios investigating contaminant movement. More than 17,900 well logs from the Wellogic database were analyzed to determine the thickness and extent of Saginaw aquifer-system units (sandstones, the interbedded series, and shale beds). The Saginaw Formation materials were divided into an uppermost shale unit overlying three aquifer units that are separated by an interbedded series consisting of shale and sandstone lenses and 


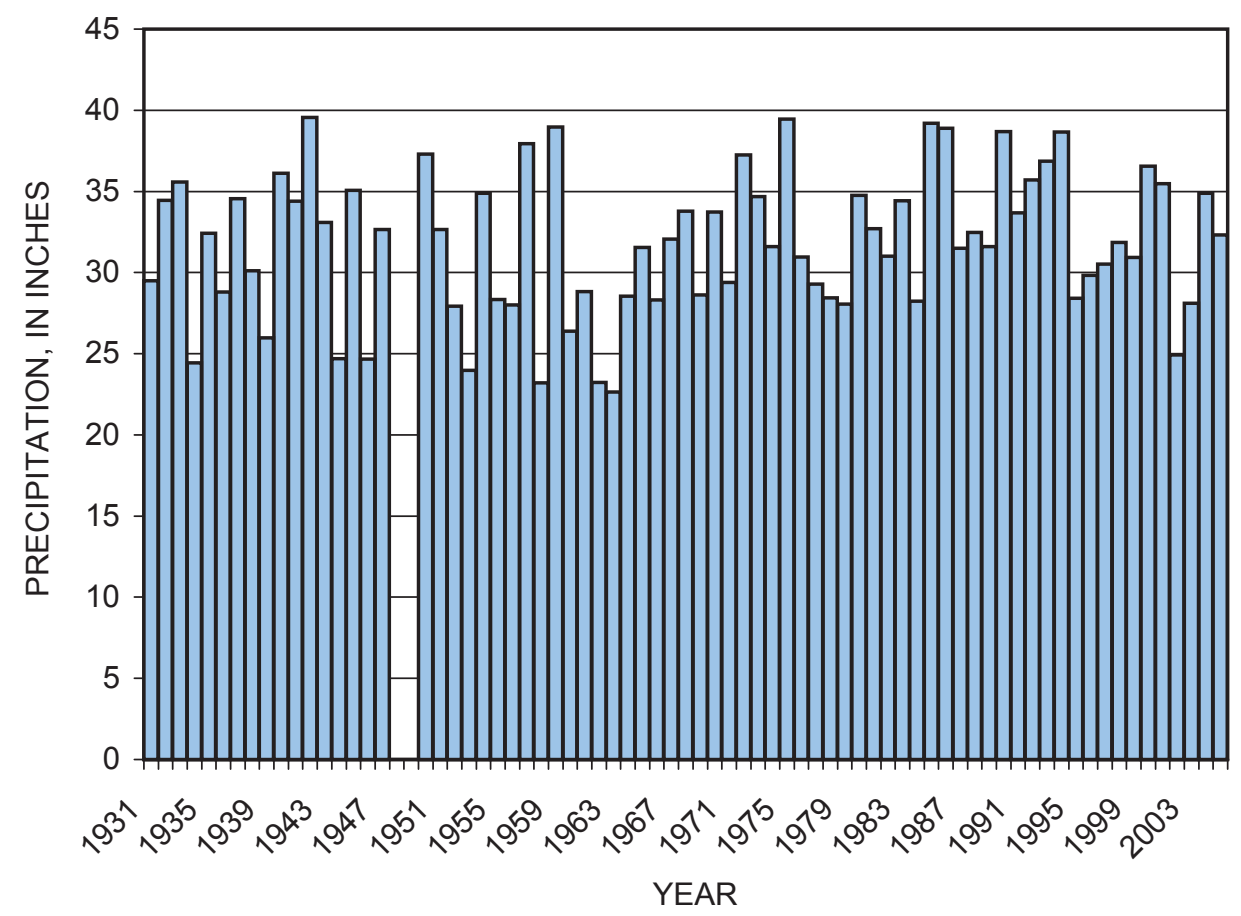

Figure 9. Annual average precipitation in the Tri-County region, Michigan. (No data available for 1948-49. Average precipitation for reported data at stations from Lansing Capital City Airport, 1948-2006; St. Johns, 1938-2006; Charlotte, 1931-2006; Dimondale 1 WSW, 1978-2004; Eaton Rapids, 1941-2006; Grand Ledge 1 NW, 1941-2002; East Lansing Experiment Farm, 1949-1960; East Lansing 4S, 1957-2006; and Williamston 3NE, 1921-2006.)

a lowermost shale unit. The uppermost shale confining unit (layer 4) ranges in thickness from 0 to $117 \mathrm{ft}$ and is thickest in Clinton County and the northern part of Eaton County. The shale unit is absent in parts of Lansing and is thinnest over most of southern Ingham and Eaton Counties. The uppermost sandstone aquifer unit (layer 5) ranges in thickness from 0 to $130 \mathrm{ft}$ and is thickest in the central Tri-County region and northern Clinton County. The interbedded-series confining unit (layer 6) ranges in thickness from 0 to $158 \mathrm{ft}$ and is thickest in the eastern, western, and northern Tri-County region. The intermediate sandstone aquifer unit (layer 7) ranges in thickness from 0 to $154 \mathrm{ft}$ and is thickest in central and northern part of the Tri-County region. The lower shale confining unit (layer 8) ranges in thickness from 0 to $150 \mathrm{ft}$ and is thickest in the central and northern part of the Tri-County region. The lowermost sandstone aquifer unit (layer 9) ranges in thickness from 0 to $200 \mathrm{ft}$ and is thickest in Ingham and Eaton County.

\section{Boundary Conditions}

Boundary conditions refer to hydraulic conditions at cells where flow can enter or exit the model. Boundaries are classified as either external or internal. External boundaries form a perimeter around, and define, the active model area. Internal boundaries represent river locations using head-dependent- flow cells and recharge using specified-flow cells. Boundary conditions are specified for each layer of the model.

Boundary conditions for the upper three layers of the model that represent the glacial deposits consist of both external and internal boundaries. External boundaries for the upper layer are constant head and no flow. No-flow boundaries are located at surface-water drainage divides and groundwater divides; constant-head cells are located along the Grand River on the south and the Maple and Grand Rivers on the north. The upper boundary of the upper layer is the water table, which is represented as specified flow and receives flow at a rate equal to recharge to the system. Internal boundaries for the upper three layers are head-dependent-flow cells representing rivers and lakes. Head values for the rivers and lakes were based on contour data shown on USGS 7.5-minute topographic quadrangle maps; linear interpolation was used, where necessary, to estimate values at cells between contours. Flow into or out of river cells is governed by stream stage, simulated head in the river cell, and conductance of the streambed material (McDonald and Harbaugh, 1988). River cells are located in glacial layers 1, 2, and 3 and in the layer 4 shale where the Saginaw Formation crops out near Grand Ledge in Eaton County. In addition to the internal river boundary cells, external boundary conditions for layer 4 simulating the upper bedrock shale unit are represented by no-flow cells. 
Boundary conditions for the lower six layers representing the remaining bedrock units are constant head and no flow. No-flow boundaries are along the boundaries of the outermost active cells in the upper layers, except where constant-head cells are along Grand River on the south. For the most part, the no-flow cells are located where little sandstone is present in the Saginaw Formation. In the north, the no-flow cells cause water to discharge to the Grand and Maple Rivers, consistent with the conceptual model. The lower boundary of the lowermost layer is the bottom of the model and is assumed to be a no-flow boundary.

\section{Hydraulic Properties}

Hydraulic properties used in model simulations include layer hydraulic conductivities and leakances and streambed conductances. Aquifer hydraulic properties affect groundwater flow through model layers; estimates for both horizontal and vertical hydraulic conductivities are described in subsequent sections. Leakances affect groundwater flow between layers. In MODFLOW, leakances, calculated from the vertical hydraulic conductivities and the layer thicknesses of the overlying and underlying layers, were calculated during model simulations and are not described further in this section. Streambed conductance affects vertical flow of groundwater from an aquifer to a river (stream) or from a river (stream) to an aquifer.

The hydraulic properties of the glacial and bedrock aquifers and confining units were based on the estimated values determined for the 1996 model. These estimates were, in turn, based on values from previous studies, analysis of aquifer-test and recovery data compiled prior to this study, and representative values reported by Freeze and Cherry (1979).

Initial estimates of hydraulic conductivity ranged from 22.3 to $87.5 \mathrm{ft} / \mathrm{d}$ for the glacial aquifer units (model layers 1, 2, and 3). Horizontal hydraulic conductivity estimates are highest in the central and eastern parts of the model area and lowest in the northern and southern parts of the model area. Vertical hydraulic conductivity estimates were initially determined to be 0.1 times the horizontal hydraulic conductivity of the glacial layers.

In order to better represent the connection between the glacial and bedrock aquifer materials, initial estimates of the hydraulic conductivity for the shale confining unit (model layer 4) were based on the materials making up the lowermost glacial unit and the uppermost bedrock unit. Well locations with glacial aquifer materials directly overlying a bedrock sandstone unit were assigned higher hydraulic conductivities than locations with till overlying shale. Initial estimates ranged from 0.0004 to $0.435 \mathrm{ft} / \mathrm{d}$. Layer 4 horizontal hydraulic conductivity estimates are highest in the southern model area and lowest in the central and northeastern model area.

The initial estimate for the horizontal hydraulic conductivity of the sandstone bedrock aquifer units (model layers 5, 7 , and 9) was specified as a constant value of about $11 \mathrm{ft} / \mathrm{d}$. The sandstone transmissivity estimates vary according to the sandstone thickness and are highest in the central and northern model area and lowest in the southern model area. Vertical hydraulic conductivity estimates were initially determined to be 0.1 times the horizontal hydraulic conductivity of the sandstone layers.

Initial estimates for the horizontal hydraulic conductivity of the interbedded-series confining unit (model layer 6) and the lowermost shale confining unit (model layer 8) were $0.1 \mathrm{ft} / \mathrm{d}$ and $0.01 \mathrm{ft} / \mathrm{d}$, respectively. Vertical hydraulic conductivity estimates were initially determined to be 0.1 times the horizontal hydraulic conductivity of each bedrock unit. The horizontal hydraulic conductivity for the bottom bedrock unit was estimated to be a constant value of $8 \mathrm{ft} / \mathrm{d}$, and the vertical hydraulic conductivity was estimated to be 0.1 times the horizontal value, or $0.8 \mathrm{ft} / \mathrm{d}$.

Streambed conductance is calculated as the product of the hydraulic conductivity of the streambed materials, stream length, and stream width, divided by the streambed thickness. Stream lengths for cells representing rivers were equal to the length of the stream segment in each cell. Stream widths varied according to the size of the stream and were assigned values ranging from $10 \mathrm{ft}$ for most streams to $300 \mathrm{ft}$ for the Grand River. Streambed thicknesses were assumed to equal $1 \mathrm{ft}$. Streambed hydraulic conductivities initially were assigned an estimated value of $2.3 \mathrm{ft} / \mathrm{d}$ (which had been previously determined during calibration of the 1996 model).

\section{Groundwater Withdrawals}

Groundwater withdrawals were simulated in those cells containing a pumping well from each layer corresponding to an open interval in the well and were based on estimated or reported values. Simulated groundwater withdrawals for the steady-state model corresponded to the average of 1991-95 pumping conditions so that model results calculated by the refined 2009 ten-layer model could be compared to simulated model results calculated by the 1996 two-layer model. Groundwater withdrawals totaled $42.6 \mathrm{Mgal} / \mathrm{d}$ in the steadystate model. Groundwater withdrawals from the glacial aquifer were simulated by use of the WEL package (McDonald and Harbaugh, 1988) as being withdrawn from model layer 3. Groundwater withdrawals from the bedrock aquifer were simulated by use of the MNW package (Halford and Hanson, 2002), with the open interval determined from well logs as the interval between the bottom of the casing and the bottom of the well; withdrawals from wells could then be simulated throughout the entire thickness of the modeled bedrock unit ranging from model layers 4 thru 10 . The MNW package allows simulation of wells that are completed in multiple aquifer units and distributes withdrawals among model layers on the basis of water-level differences and the hydraulic characteristics of the units intercepted by the simulated well. For the transient simulations, pumping rates were varied according to estimated or measured rates and ranged from $3.6 \mathrm{Mgal} / \mathrm{d}$ prior to 1920 (stress period 2) to $46.1 \mathrm{Mgal} / \mathrm{d}$ in 2005 (stress period 17). For the transient simulations representing monthly 
conditions, pumping rates were varied to represent monthly averages in 2005. Monthly withdrawals were highest from June to September and ranged from $36.3 \mathrm{Mgal} / \mathrm{d}$ in December to $51.3 \mathrm{Mgal} / \mathrm{d}$ in September.

\section{Steady-State Model Calibration}

Model calibration is the process of reducing the difference between observed and simulated water levels and streamflows by adjusting model parameters. MODFLOW-2000 (Hill and others, 2000) contains observation, sensitivity, and parameter-estimation processes as part of the groundwatermodeling computer program. The observation process allows comparison of observed and model-calculated values. The sensitivity process determines the sensitivity of predicted hydraulic heads and flows to specified model parameters or, in combination with the observation process, determines sensitivities for the simulated values associated with observations (Hill and others, 2000). The parameter estimation process is described later in this section.

Model fit is evaluated by comparing the magnitude and distribution of the residuals between simulated and observed water levels and flows. Simulated water levels and flows can be plotted against observed values, and the deviation from a straight line gives one indication of model fit. Plotting the residuals, which are the observed minus the simulated values, shows the distribution and indicates possible biases in the model. A generally random distribution of positive and negative water-level residuals can indicate that the model is not overpredicting or underpredicting water levels over parts of the model area. For this study, model calibration was achieved by manual trial-and-error adjustment of parameters and by use of the automated parameter-estimation program in MODFLOW-2000.

For the steady-state model simulation, available miscellaneous and continuous water-level and flow observations compiled for the 1996 model were used for calibration. These observations were weighted for the parameter-estimation process to account for differences in measurement accuracy and differences in units of measurement. This weighting strategy allows those measurements with a higher degree of confidence to have more effect on parameter estimates and ensures that both water-level and flow data, which are measured in different units, affect parameter estimates. Water-level observations collected during this or previous USGS studies generally were assigned a higher degree of confidence because datums commonly are established by field surveys and measurements are obtained by use of well-documented protocols. Water-level observations from other sources were assigned a lower degree of confidence because of the uncertainty associated with estimating a datum from a topographic map, measuring depth to water in a recently developed or currently used domestic well, and fluctuations in levels of surface-water bodies. Streamflow data included daily mean discharge data from streamgaging stations and miscellaneous streamflow-measurement data from sites where continuous data are not collected.
Parameterization is the process of identifying those aspects of the simulated groundwater-flow system that are to be represented by estimated parameters (Hill and others, 2000). Possible choices for parameters in a groundwater-flow model include groundwater recharge rates and the hydraulic characteristics of the aquifers, confining units, and streambed materials. Typically, it is impossible to estimate all parameters of interest because of limitations in the datasets available for calibration. Therefore, in this study, automated parameter estimation was combined with manual adjustments of some parameters to investigate their effects on model fit. Parameters were selected to scale the initial estimates of horizontal and vertical hydraulic conductivity for each model layer, the initial estimate of riverbed conductance, and the initial estimate of recharge. Examination of parameter sensitivities by use of processes within the model indicated that the parameters representing recharge, horizontal hydraulic conductivities in layers in $1,5,7$, and 9 , and vertical hydraulic conductivities in layers 4 and 8 had the highest sensitivities and were most likely candidates for parameter estimation (that is, predicted heads and/or flows would be the most sensitive to changes in these parameters).

All initial model-parameter estimates were based on final parameter estimates from the calibrated 1996 model except the estimated vertical hydraulic conductivities of the glacial and Saginaw aquifers and the estimated hydraulic properties for the bedrock shale layers. The 1996 model represented the glacial and Saginaw units as individual layers; the 2009 model represents the glacial unit as three layers and the Saginaw as seven. The initial estimate for the glacial vertical hydraulic conductivity was based on the 1996 model estimate of vertical leakance between the glacial and Saginaw layers because this value itself was based primarily on the glacial materials. During calibration, this initial estimate was found to be too low and the model would not converge; therefore, it was multiplied by 10 for each glacial layer (table 3). The estimate of glacial horizontal hydraulic conductivity ranged from 12.7 to $107.2 \mathrm{ft} / \mathrm{d}$, and the vertical hydraulic conductivity estimate ranged from 0.0001 to $0.027 \mathrm{ft} / \mathrm{d}$. The estimated horizontal hydraulic conductivity for the shale (layer 4) ranged from 0.01 to $4.5 \mathrm{ft} / \mathrm{d}$, and the vertical hydraulic conductivity estimate ranged from 0.000009 to $0.0032 \mathrm{ft} / \mathrm{d}$. The estimated horizontal hydraulic conductivity of the sandstone (layers 5, 7, and 9) equaled $11 \mathrm{ft} / \mathrm{d}$, and the vertical hydraulic conductivity estimate equaled $1.1 \mathrm{ft} / \mathrm{d}$. Horizontal hydraulic conductivity estimates for the interbedded series (layer 6) and the lower shale (layer 8 ) equaled $0.1 \mathrm{ft} / \mathrm{d}$ and $0.01 \mathrm{ft} / \mathrm{d}$, respectively. The estimated riverbed conductance was doubled to equal $4.6 \mathrm{ft} / \mathrm{d}$. Simulation results for the refined 2009 ten-layer model were compared to simulated values from the 1996 two-layer model. The agreement between observed and simulated groundwater levels and streamflow was similar for the two models (fig. 10). The sum of squared weighted residuals (SSWR) for heads decreased from 16,170 in the 1996 model to 10,452 in the 2009 model; the SSWR for streamflow measurements increased slightly from 350 in the 1996 model to 415 in the 2009 model. 
Table 3. Parameter estimates for coefficients multiplying matrices that describe the spatial variation of hydraulic properties in the Tri-County region, Michigan.

\begin{tabular}{|c|c|c|c|c|c|}
\hline \multirow{2}{*}{$\begin{array}{l}\text { Layer } \\
\text { number }\end{array}$} & \multirow{2}{*}{ Description } & \multicolumn{2}{|c|}{ Horizontal hydraulic conductivity } & \multicolumn{2}{|c|}{ Vertical hydraulic conductivity } \\
\hline & & Initial & Final & Initial & Final \\
\hline 1 & Glacial materials & 1.0 & 1.2 & 10.0 & 5.0 \\
\hline 2 & Glacial materials & 1.0 & 1.2 & 10.0 & 5.0 \\
\hline 3 & Glacial materials & 1.0 & 1.2 & 10.0 & 5.0 \\
\hline 4 & Upper shale unit & 1.0 & 1.0 & 1.0 & .5 \\
\hline 5 & Upper sandstone aquifer & 1.0 & .75 & 1.0 & 1.0 \\
\hline 6 & Interbedded series unit & 1.0 & 1.0 & 1.0 & .1 \\
\hline 7 & Intermediate sandstone aquifer & 1.0 & .75 & 1.0 & 1.0 \\
\hline 8 & Lower shale unit & 1.0 & 1.0 & 1.0 & 1.0 \\
\hline 9 & Lower sandstone unit & 1.0 & .75 & 1.0 & 1.0 \\
\hline 10 & Saginaw confining unit/Parma & 1.0 & 1.0 & 1.0 & 1.0 \\
\hline
\end{tabular}

\section{Transient Model Development and Calibration}

Development of a transient model builds on the existing knowledge and input data for the steady-state model and allows investigation of changes in stresses, such as pumping or recharge, while accounting for changes in storage. For the transient model simulations, additional information must be specified, including the storage characteristics of the aquifers, and the initial conditions. Storativity describes the capacity of an aquifer to transfer water to and from storage (Anderson and Woessner, 1992). For a confined aquifer, the storage coefficient is equal to the volume of water released per unit area of aquifer per unit decline in head. For an unconfined aquifer, the equivalent term is specific yield, which is defined as the volume of water released per unit surface area of aquifer per unit decline in the water table. The initial conditions define the head distribution at the beginning of the simulation and serve as a boundary condition in time.

Typically, storage coefficients range from $1.0 \times 10^{-3}$ to $1.0 \times 10^{-5}$ for confined aquifers (Freeze and Cherry, 1979). The specific yields of unconfined aquifers are generally higher than the storativities of confined aquifers and range from about 0.01 to 0.45 (Anderson and Woessner, 1992). Releases from storage in unconfined aquifers represent an actual dewatering of soil pores, whereas releases from storage in confined aquifers represent only the secondary effects of water expansion and aquifer compaction caused by changes in fluid pressure (Freeze and Cherry, 1979). In the model, the specific yield of the upper glacial layers was estimated to be 0.1 , whereas the initial estimate of storage coefficient for the bedrock layers was $1.0 \times 10^{-5}$. The sensitivity of model results to these values was investigated during model calibration.

As with the steady-state model, transient model calibration also was achieved by manual trial-and-error adjustment of parameters and by use of the automated parameter-estimation program in MODFLOW-2000. Available miscellaneous and continuous water-level and flow observations from USGS observation locations and the Wellogic database were used for calibration (table 4). As in the steady-state model, parameter sensitivities indicated that horizontal hydraulic conductivities for layers 1, 5, 7, and 9 and the vertical hydraulic conductivity for layer 4 had the highest sensitivities and were most likely to be able to be estimated by parameter estimation. These values were adjusted during model calibration, along with the riverbed conductance and vertical hydraulic conductivity of the interbedded series. During the initial calibration runs, all layers were represented as confined. During final calibration runs, the glacial units (layers 1,2, and 3) were represented as unconfined with rewetting of dry cells active. The final estimates for the multiplication coefficients that scale the initial estimates of horizontal and vertical hydraulic conductivity for each model layer and the initial estimate of riverbed conductance are listed in table 3.

Simulated water levels and streamflows for each stress period of the transient simulation were compared to observed water levels and flows (figs. 11-13). In most cases, the simulated water levels were higher than observed water levels, especially during the stress periods in the middle of the transient simulation in which pumping was concentrated in a small part of the model area. However, many observations were near pumping wells. The simulated water level represents the average water level in the cell in each layer; that is, the average of the lowered water levels at the well location and the higher water levels away from the well and beyond the cone of depression formed as a result of groundwater withdrawals. This model-simulated value is not the actual water level that would be observed in a well pumping in an area with the layer and hydraulic characteristics that are used in the model and, thus, cannot be compared directly with the actual observed drawdown at the pumping well. Drawdown at the location of 


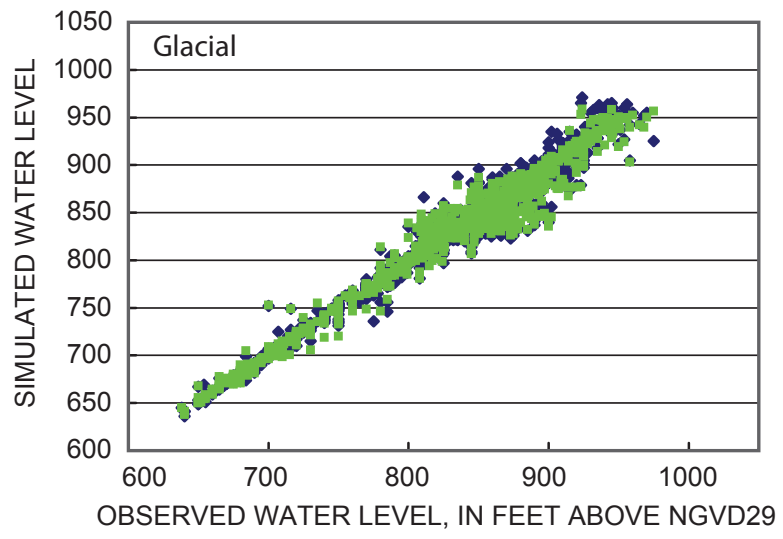

- 2009 model -1996 model

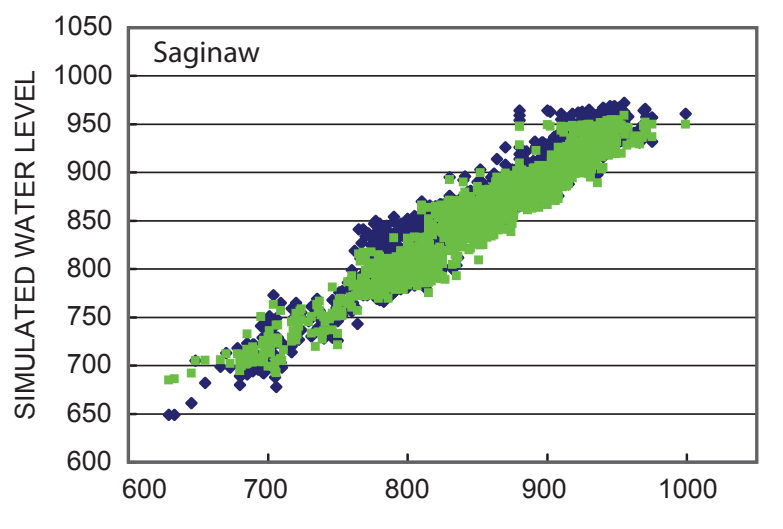

OBSERVED WATER LEVEL, IN FEET ABOVE NGVD29

- 2009 model -1996 model

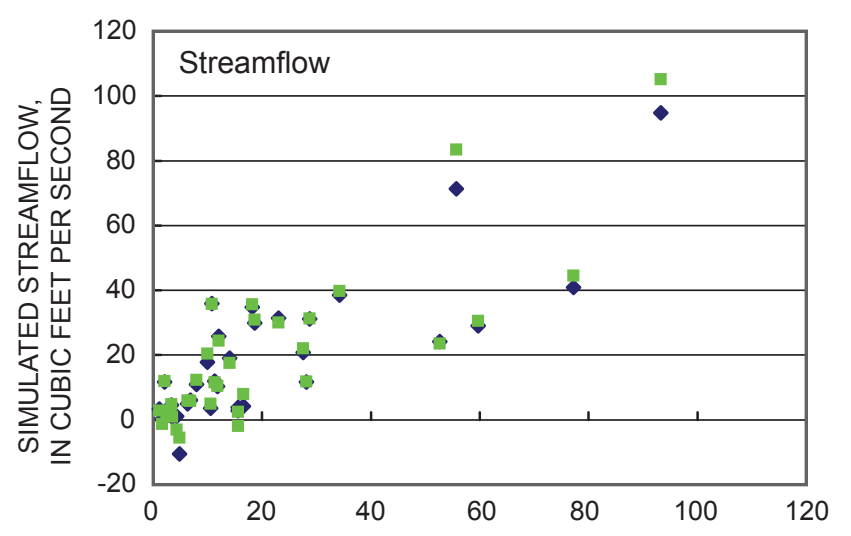

OBSERVED STREAMFLOW, IN CUBIC FEET PER SECOND

- 2009 model 1996 model

Figure 10. Relations between simulated water levels in the glacial deposits and Saginaw aquifer, and streamflow from the 1996 and 2009 models in the Tri-County region, Michigan. the well in the cell would be greater than the simulated value. The simulation results from the transient stress periods do match the trend in water levels seen for the observation wells in the area. Simulated streamflows also generally match the trends determined from base-flow measurements for gaging stations in the model area; however, the simulated streamflows are generally lower than the observed values. Streamflow varies from year to year and within any given year. Base-flow measurements were based on available data; however, not all streams were gaged during the entire period of the transient simulation. Therefore, some base-flow estimates were based on data from only a few years of the transient stress period and may not have been representative of the actual base flow that occurred during the entire time interval represented by the stress period. In addition, the transient model does not include any water that is added to the stream from any external point source, such as from a water-treatment plant, so simulated values are expected to be lower than actual observed values.

Simulation results can be analyzed to show the waterbudget components and the changes in these components over time (fig. 14). The major components of the Tri-County model budget are recharge into the groundwater system and discharge out of the groundwater system to streams and surfacewater features (fig. 14a). Recharge from streams and other surface-water features and discharge out of the groundwater system through the model boundaries (along the Maple and Grand Rivers, which are represented as constant head cells in the model) are the next most important fluxes in the modeled area. Compared to the major components, withdrawal of water by wells is a relatively small component of the overall groundwater-system budget. With development and the addition of wells, a new discharge is superimposed upon a previously stable system that is at equilibrium, and it must be balanced by an increase in the recharge of an aquifer, or by a decrease in the old natural discharge, or by a loss of storage in the aquifer, or by a combination of changes in recharge, discharge, or storage. The relative contributions of changes in storage, changes in recharge, and changes in discharge evolve with time, potentially over a period of years, decades, or even centuries. The long-term source of water to discharging wells typically is a change in the amount of water entering or leaving the system. The role of pumping and changes in storage over time is more evident in the changes in the water-budget components over time (fig. $14 \mathrm{~b}, \mathrm{c}$ ); model results indicate that changes in storage occur mostly in response to changes in recharge. Recharge into the groundwater system and discharge to streams and surface-water features are the water-budget components with the largest changes.

\section{Sensitivity Analysis}

The calibrated model is influenced by uncertainty in the model parameters, which are average values based on limited data available from well drillers' logs or previous studies. A sensitivity analysis can help determine the effect of uncertainty in the estimated aquifer parameters, stresses, and 
Table 4. Water-level observations used in transient model calibration for the Tri-County region, Michigan.

[Wellogic is an electronic database of water well records that is maintained by the Michigan Department of Environmental Quality. "--" denotes no observation wells available]

\begin{tabular}{|c|c|c|c|c|c|}
\hline \multirow{2}{*}{$\begin{array}{l}\text { Stress } \\
\text { period }\end{array}$} & \multirow{2}{*}{$\begin{array}{l}\text { Time interval } \\
\text { represented by } \\
\text { stress period }\end{array}$} & \multicolumn{2}{|c|}{ USGS observation wells } & \multicolumn{2}{|c|}{ Wellogic database wells } \\
\hline & & $\begin{array}{l}\text { Observations in the } \\
\text { Saginaw aquifer }\end{array}$ & $\begin{array}{l}\text { Observations in the } \\
\text { glacial aquifer }\end{array}$ & $\begin{array}{c}\text { Wells in the } \\
\text { Saginaw aquifer }\end{array}$ & $\begin{array}{l}\text { Wells in the } \\
\text { glacial aquifer }\end{array}$ \\
\hline 1 & Predevelopment & - & - & - & - \\
\hline 2 & Pre-1920 & - & - & 1 & - \\
\hline 3 & $1921-38$ & 2 & - & - & - \\
\hline 4 & $1939-48$ & 8 & 1 & 18 & 2 \\
\hline 5 & $1949-54$ & 11 & 1 & 18 & 1 \\
\hline 6 & $1955-62$ & 15 & 1 & 50 & - \\
\hline 7 & $1963-68$ & 20 & 3 & 929 & 50 \\
\hline 8 & $1969-72$ & 20 & 3 & 1056 & 128 \\
\hline 9 & $1973-82$ & 20 & 3 & 1338 & 437 \\
\hline 10 & $1983-90$ & 19 & 3 & 1084 & 389 \\
\hline 11 & $1991-95$ & 18 & 3 & 1022 & 101 \\
\hline 12 & $1996-99$ & 6 & 1 & 1007 & 81 \\
\hline 13 & 2000-2001 & 6 & 2 & 1094 & 357 \\
\hline 14 & 2002 & 6 & - & 982 & 243 \\
\hline 15 & 2003 & 10 & 1 & 830 & 199 \\
\hline 16 & 2004 & 6 & - & 302 & 27 \\
\hline 17 & 2005 & 15 & 3 & 98 & 16 \\
\hline
\end{tabular}

boundary conditions on model results. During a sensitivity analysis, calibrated values for model parameters are systematically changed within reasonable ranges to determine the magnitude of the changes in water levels and streamflows from the calibrated solution (Anderson and Woessner, 1992). Model sensitivity as described by the SSWR (sum of squared weighted residuals) or simulated water levels and flows was investigated by increasing and decreasing the multiplication coefficient for each hydraulic property. In some cases, the change had little effect on model results; in other cases, the change had a substantial effect, or the model failed to converge. The transient model was most sensitive to changes in horizontal and vertical hydraulic conductivities in the glacial units (layers 1,2, and 3), vertical hydraulic conductivity in the shale unit (layer 4), horizontal hydraulic conductivities in the sandstone (layers 5, 7, and 9), and vertical hydraulic conductivity in the interbedded series (layer 6). With higher glacial horizontal hydraulic conductivity, the SSWR was generally higher for both water-level and streamflow observations; the water-table surface was generally lower during early stress periods, with more drawdown during later stress periods. With higher glacial vertical hydraulic conductivity, the water-table surface was generally lower during early stress periods with less drawdown observed during later stress periods. Lower glacial vertical hydraulic conductivities resulted in very little change in the SSWR. Lower vertical hydraulic conductivities in the upper shale unit resulted in lower water levels; however, some changes in this parameter resulted in model runs that did not converge. Lower horizontal hydraulic conductivities in the sandstone resulted in lower SSWR and a closer match between observed and simulated drawdowns, whereas higher horizontal hydraulic conductivities in the sandstone resulted in little change in the SSWR for water levels and streamflows. Higher vertical hydraulic conductivities in the interbedded-series values resulted in a lower initial water-level surface during early stress periods and less drawdown during later stress periods.

Transient model sensitivity to changes in the riverbed conductance, recharge, and storage parameters also was investigated during the sensitivity analysis. Both increases and decreases to the riverbed conductance parameter resulted in only slight changes in the SSWR. Changes in recharge had very little effect on simulated water levels, whereas increased recharge resulted in higher simulated streamflows. Recharge estimates for most stress periods were modified slightly within reasonable ranges to improve streamflow estimates. Storage estimates also were modified within reasonable ranges to improve the agreement between observed and model simulated values. Model fit was improved with increased glaciallayer specific yield, increased storage in shale layer 4, and increased storage in the sandstone layers. Increasing specific 


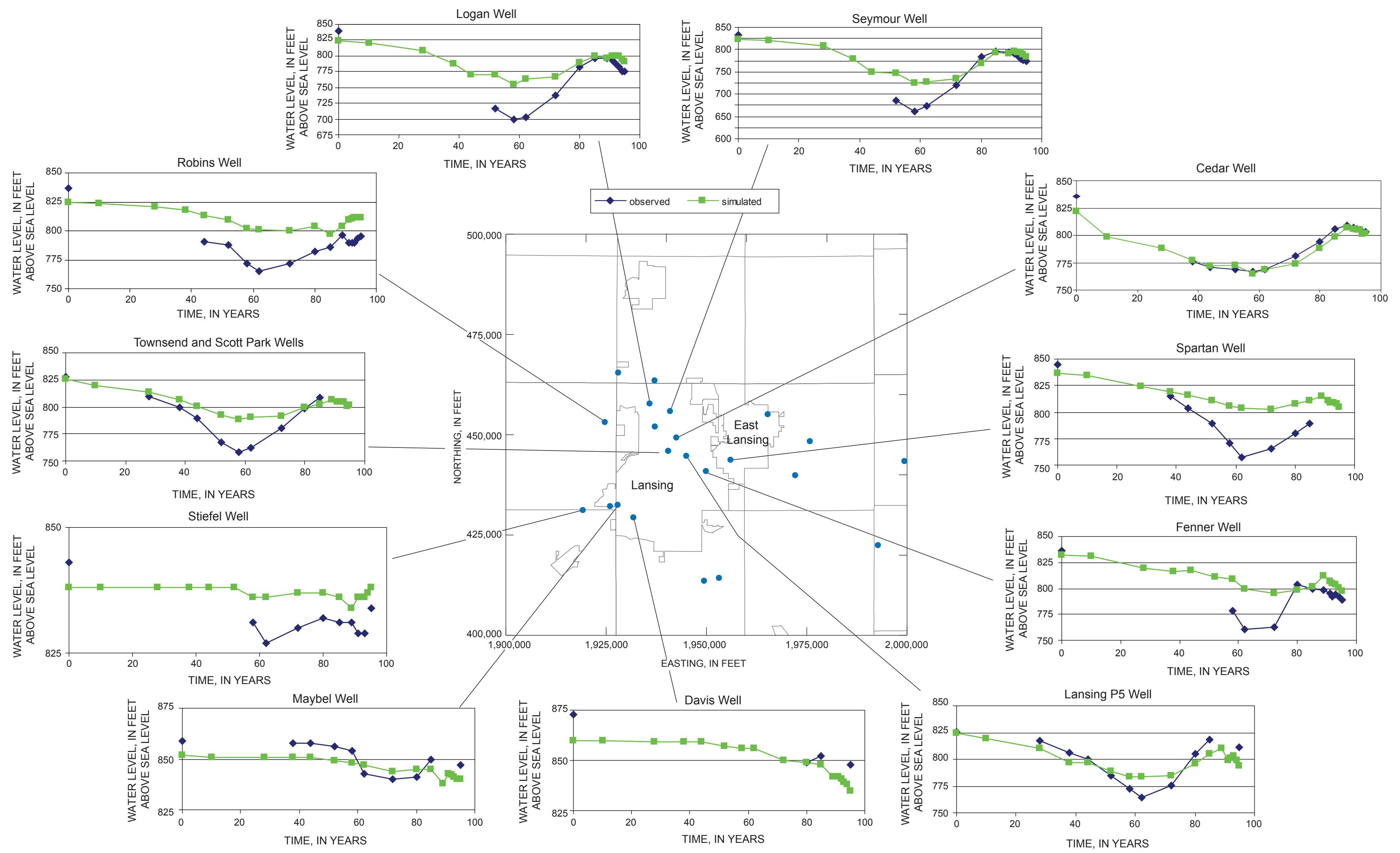

Figure 11. Relation between observed and simulated transient water levels in observation wells in the Lansing area, Michigan. 

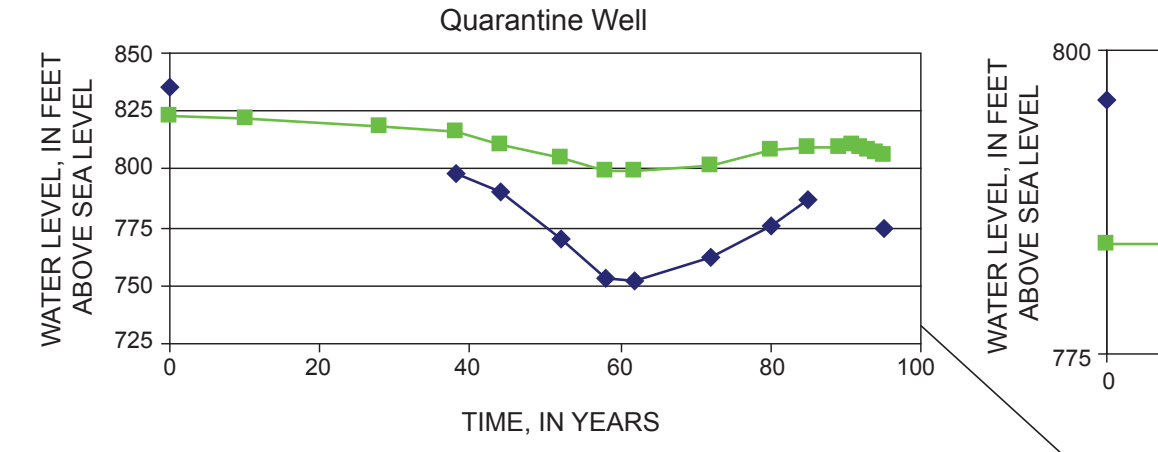

US 27 Well
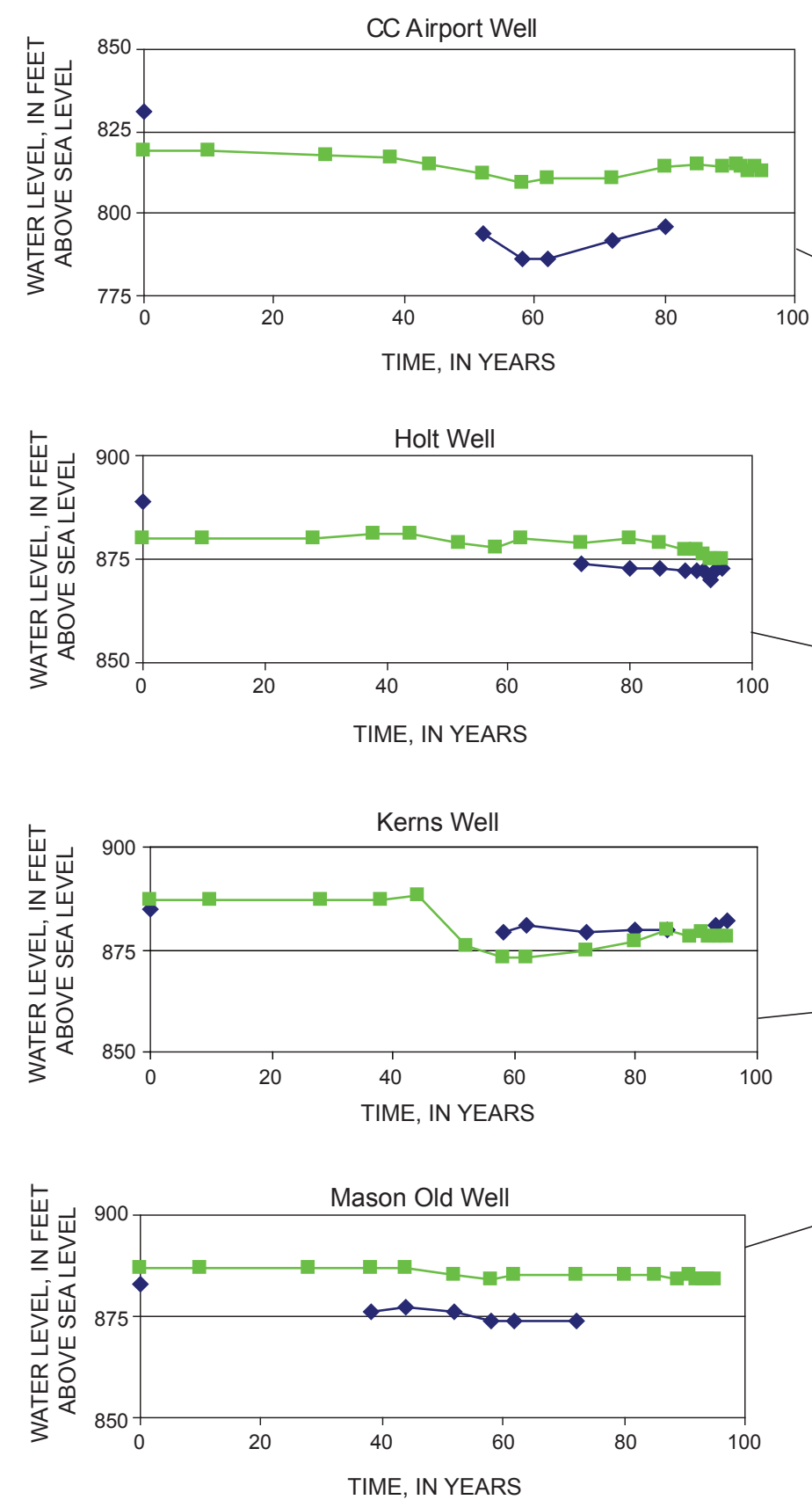

TIME, IN YEARS

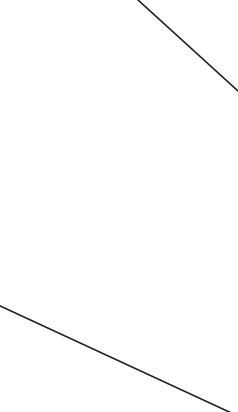

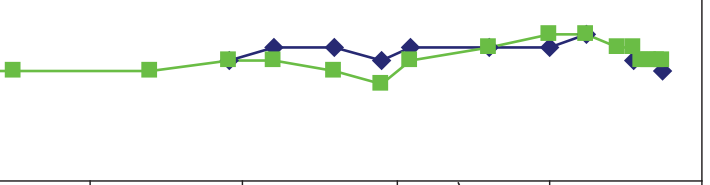

$\begin{array}{ccr}20 & 40 & 60 \\ & \text { TIME, IN YEARS }\end{array}$

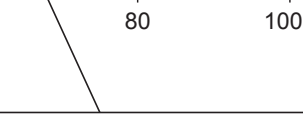
$\multimap$ observed $\rightarrow-$ simulated
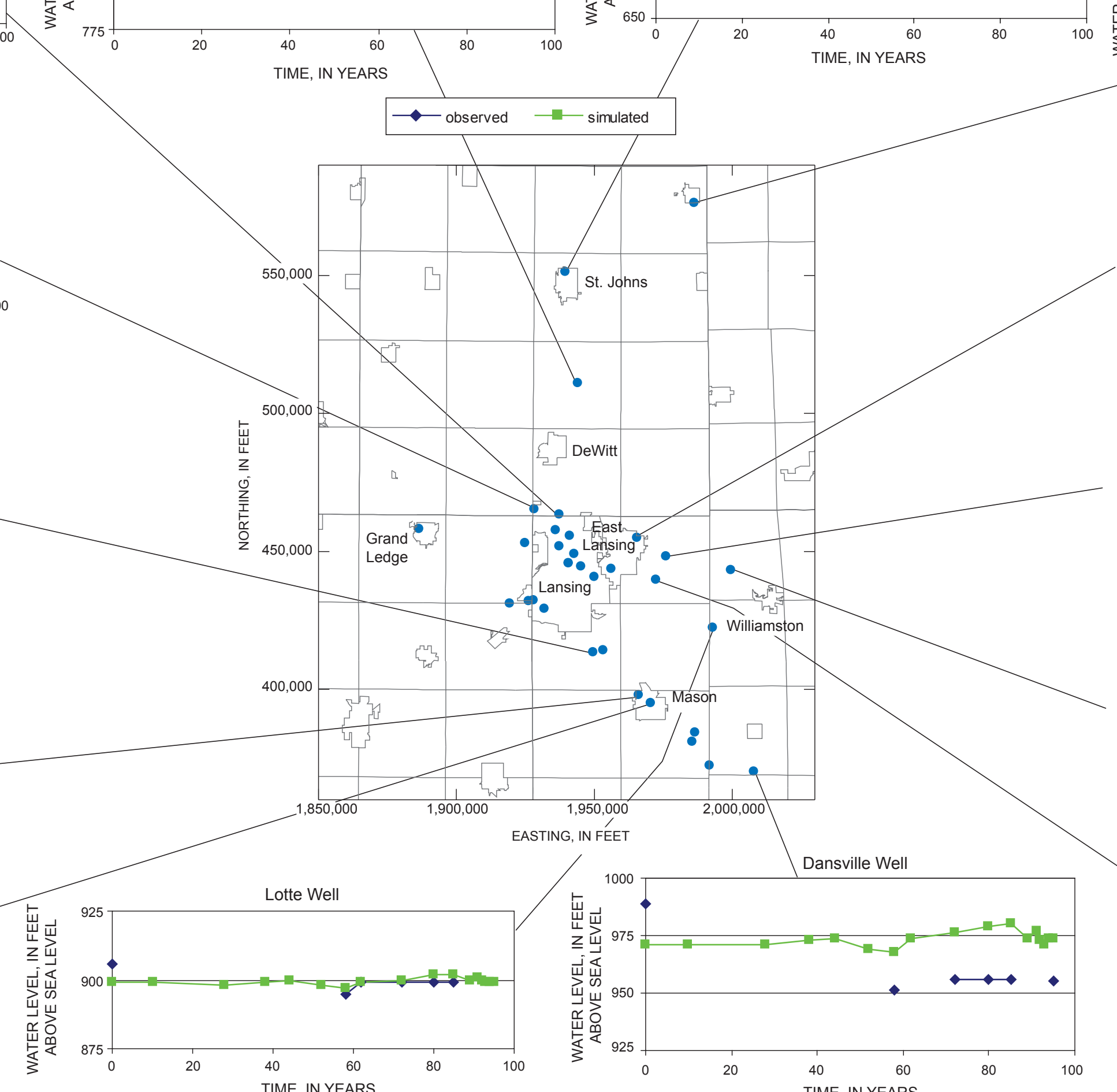

TIME, IN YEARS
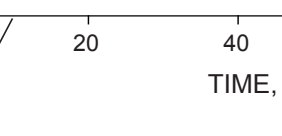

$\begin{array}{rr}40 & 60 \\ \text { TIME, IN YEARS }\end{array}$

St Johns Well
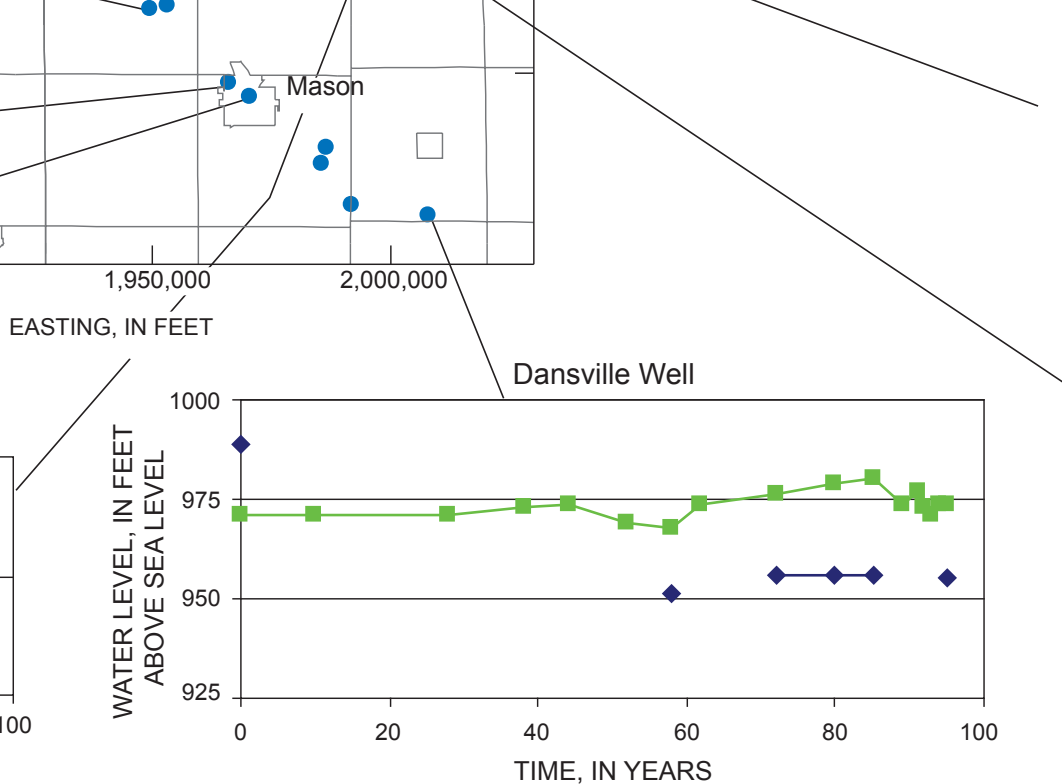

Elsie Well

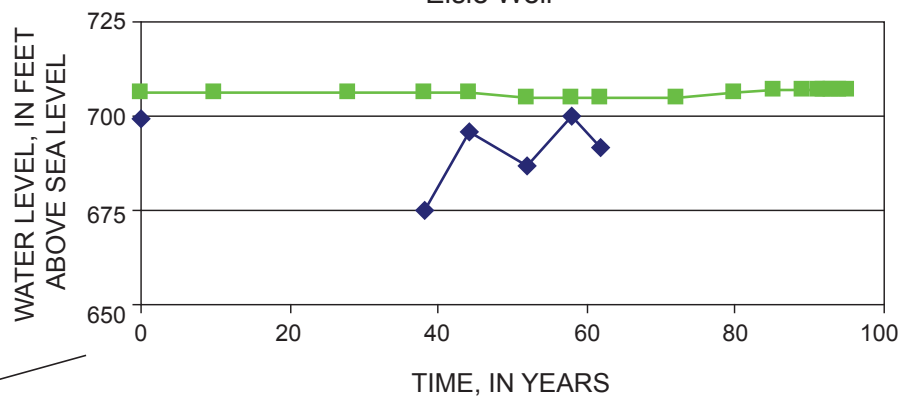

Marble Well

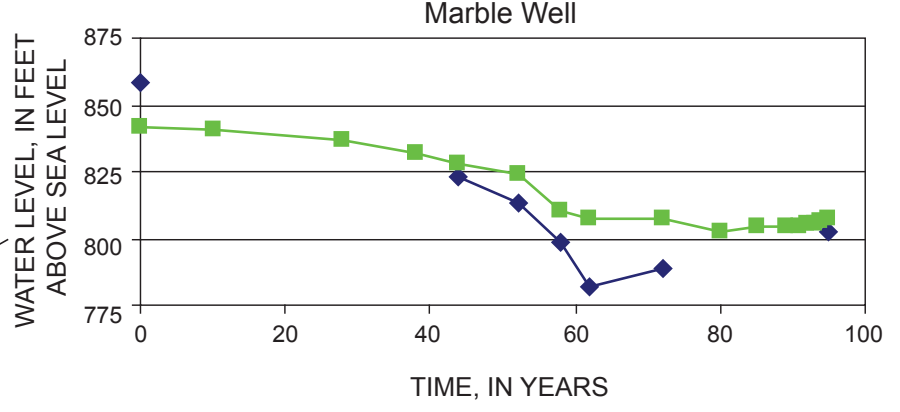

TIME, INYEARS

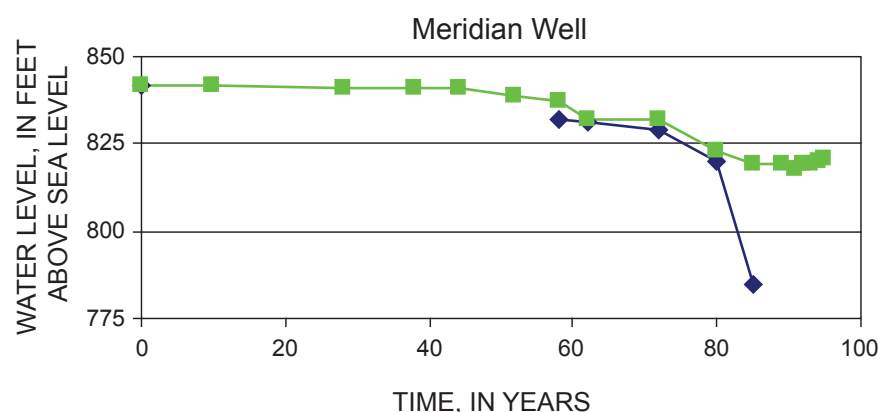

Sherwood WeIl

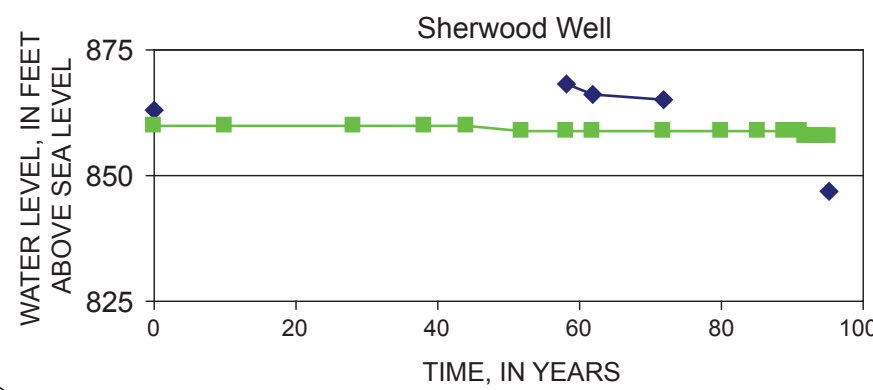

Okemos Well

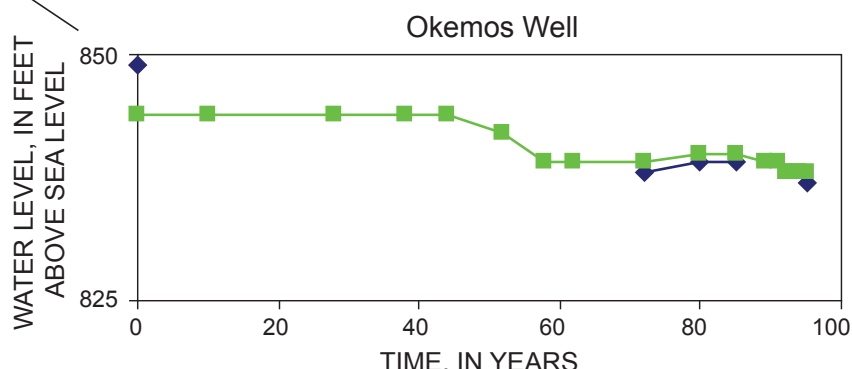

Figure 12. Relation between observed and simulated transient water levels in Tri-County-region observation wells.. 

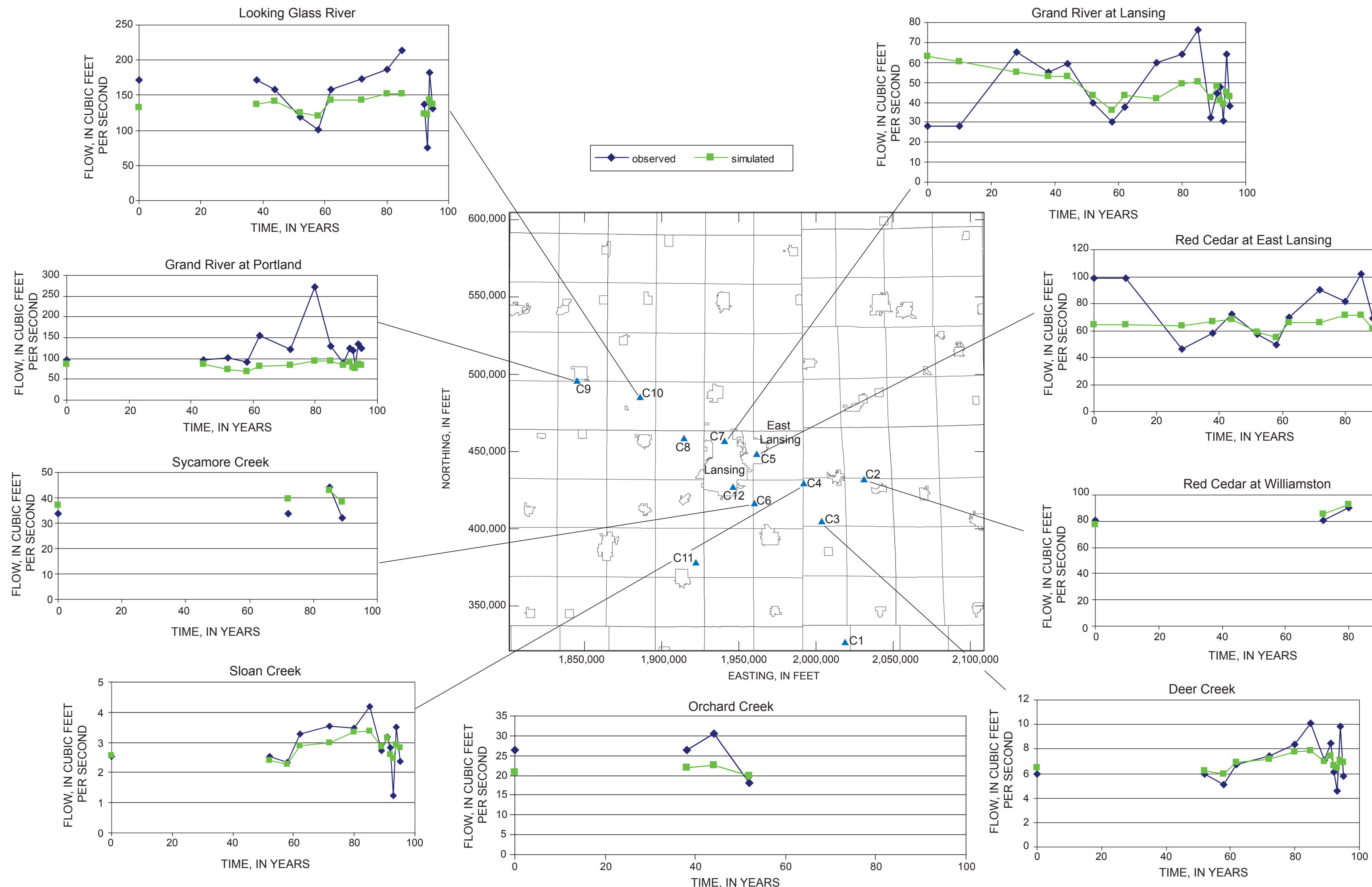

Figure 13. Relation between observed and simulated transient streamflows in the Tri-County region, Michigan 
$\boldsymbol{A}$

Water Budget by Stress Period

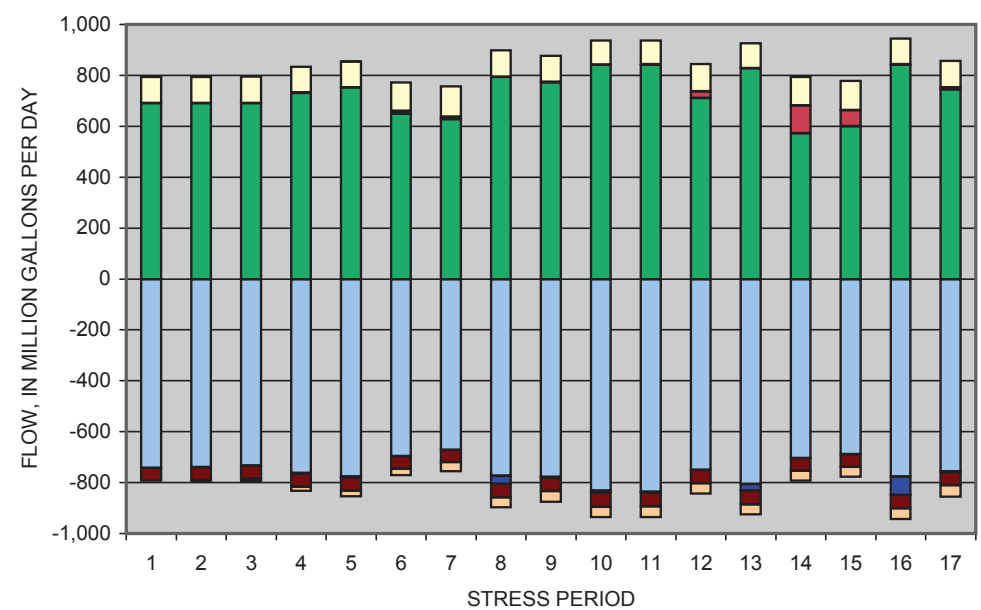

口Wells out

Boundaries out

$\square$ Storage sink

口River out

$\square$ In thru boundaries

$\square$ River in

$\square$ Storage source

$\square$ Recharge in

B Change in Water Budget Components by Stress Period

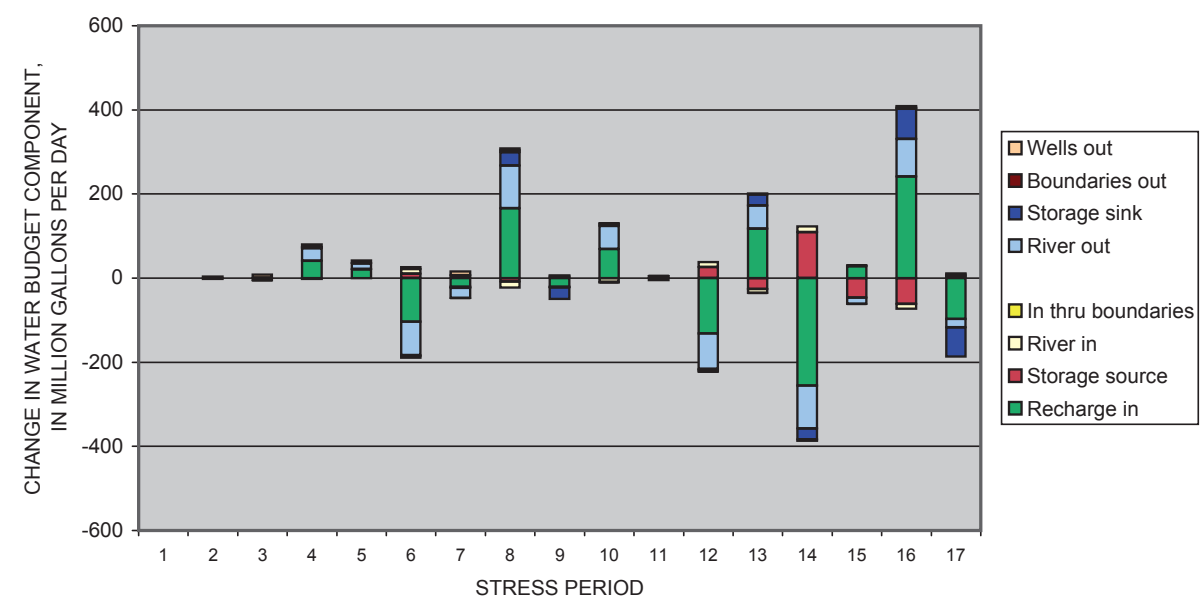

C Change in Water Budget Components by Stress Period

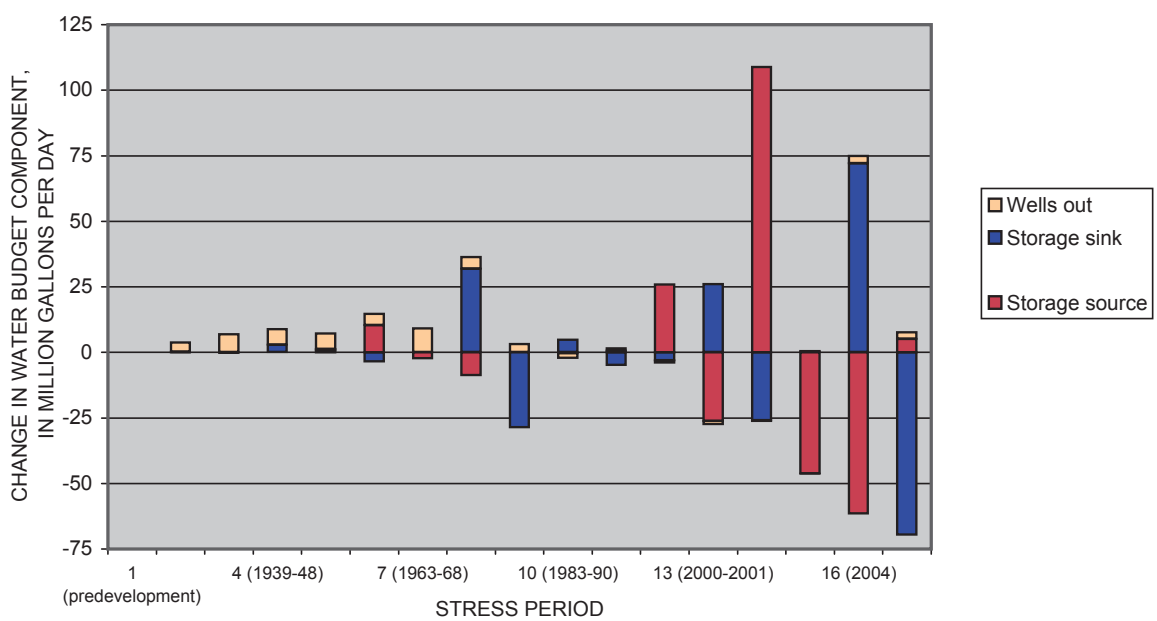

Figure 14. Water-budget components and change in components by stress period, Tri-County model. (Note change of scale between graphs $B$ and $C$.) 
yield in the layers representing the glacial aquifer continued to improve model agreement between observed and simulated water levels, but the agreement between observed and simulated streamflows worsened. Changes to storage in the interbedded series and lower shale units resulted in very little change to the calculated SSWR.

\section{Groundwater-Flow Simulations}

As stated previously, the Tri-County groundwater-flow model has been used to address numerous water-resource issues. For this study, scenarios were selected to build upon previous simulations and to advance understanding of the regional groundwater-flow system. These scenarios include (1) the potential effects of reduced recharge due to urban areas or low rainfall/drought conditions on water levels, (2) delineation of contributing areas under 2006-7 pumping conditions, and (3) optimization of pumping subject to various quality and quantity constraints.

\section{Investigation of Reduced Recharge}

Several steady-state and transient scenarios investigated changes in water levels predicted by the model with reduced recharge due to urban areas and low-rainfall/drought conditions. Simulations investigating reduced recharge in urban areas were done with both the steady-state and transient models. Simulations investigating reduced recharge due to low rainfall were done with the transient model representing monthly conditions.

To investigate spatial differences in recharge that may arise from impervious surfaces, aerial photos for the TriCounty region from 1984, 1994, and 2003 were analyzed to determine areas that are primarily urban and that are assumed for the purposes of this study to be largely impermeable. Because some of these urban areas are likely connected to storm sewers, where runoff water collects and is released into a nearby stream, this water may be unavailable to recharge the surrounding groundwater-flow system. However, rainfall on some of these areas, such as roads or rooftops, likely runs off to adjacent medians or yards where it does recharge the local groundwater-flow system. In addition, some recharge can occur beneath paved urban areas because of leaking pipes. Investigation of the nature of each urban impervious area and the status of each municipal system was beyond the scope of this study. Therefore, for model simulations, these urban areas were assumed to represent areas of reduced recharge.

Recharge rates in areas determined to be urban by aerial-photo interpretation were reduced by 20 percent and 50 percent for those model stress periods corresponding to the aerial photo dates. As mentioned above, the actual change in recharge caused by urban areas is unknown, so these reductions of 20 and 50 percent permit investigation of effects due to low or moderate reductions in recharge. Some urban areas were smaller than or only encompassed a small part of a cell; in these areas, recharge was not reduced. Urban areas for 1984, 1994, and 2003 occupied 1,902, 2,237, and 2,665 model cells, respectively. Under steady-state conditions, only urban areas based on the 2003 air photo were simulated with reduced recharge. Recharge rates also were reduced by 50 percent for an area approximately 2,000 ft surrounding Lake Lansing in Meridian Township. The potential effects of rapid growth in this area on water levels are of interest to the township. This simulation accounts for reduced recharge entering the model through the upper model surface, but it does not account for, nor reduce any, recharge that may enter the groundwater system as leakage from Lake Lansing. To fully account for the potential effects of reduced recharge due to development around the lake, flow from Lake Lansing may need to be included.

Steady-state simulation results indicate the following potential declines in hydraulic head:

- Slightly more than $2 \mathrm{ft}$ in the upper glacial unit (layer 1) and less than $2 \mathrm{ft}$ in the upper bedrock sandstone unit (layer 5) with a 20-percent reduction in recharge in urban areas.

- Slightly more than $6 \mathrm{ft}$ in the upper glacial unit (layer 1) and slightly more than $4 \mathrm{ft}$ in the upper bedrock sandstone unit (layer 5) with a 50-percent reduction in recharge in urban areas.

- Less than $0.6 \mathrm{ft}$ in the upper glacial unit (layer 1) and less than $0.2 \mathrm{ft}$ in the upper bedrock sandstone unit (layer 5) with a 50-percent reduction in recharge for the area surrounding Lake Lansing.

Transient simulation results indicate the following potential declines in hydraulic head:

- Slightly more than $1 \mathrm{ft}$ in both the upper glacial unit (layer 1) and the upper bedrock sandstone unit (layer 5) with a 20-percent reduction in recharge in urban areas.

- Slightly more than $3 \mathrm{ft}$ in the upper glacial unit (layer 1) and less than $3 \mathrm{ft}$ in the upper bedrock sandstone unit (layer 5) with a 50-percent reduction in recharge in urban areas.

- Less than $0.3 \mathrm{ft}$ in the upper glacial unit (layer 1) and less than $0.2 \mathrm{ft}$ in the upper bedrock sandstone unit (layer 5) with a 50-percent reduction in recharge for the area surrounding Lake Lansing.

Additional transient simulations investigated the impact on water levels of reduced recharge due to low-rainfall/ drought conditions and reduced recharge with increased groundwater withdrawals. During summer months, recharge to the groundwater system can be reduced by evaporation and uptake of precipitation by plants; in addition, groundwater withdrawals are often greater to meet demands such as lawn watering. Both the lowered recharge rates and increased 
groundwater withdrawals can affect water levels. Simulations with the transient model were done with 72 months (6 years) in which recharge and pumping reflected average recent conditions (as specified by the water-supply system) followed by 24 months ( 2 years) with modified recharge or modified recharge and pumping rates. Thus, at the beginning of the year with modified recharge and pumping rates, changes in storage were small (less than 2 percent) and water movement into storage approximately equaled water movement out of storage. To represent reduced recharge due to low rainfall, the recharge rate for each month was reduced by about 30 percent. The amount of reduction was varied for some summer months because of model convergence problems in the months with low recharge rates. Over the time interval for the transient model, the year of lowest precipitation was 1963 with 22.6 in., which is about 70 percent of the average rate of $32 \mathrm{in.} \mathrm{To} \mathrm{rep-}$ resent possible future groundwater-withdrawal rates, monthly rates for Lansing-area production wells were increased by 15 percent to match the average observed increase in pumping from 2004 to 2005 (table 5).

Transient simulations with reduced recharge indicate decreases in simulated water levels ranging from 0 to $6 \mathrm{ft}$ at observation-well locations and simulated streamflows ranging from 0.5 to $34.7 \mathrm{ft}^{3} / \mathrm{s}$ at streamflow-observation locations. Decreases in simulated water levels due to reduced recharge ranged from 0 to $6 \mathrm{ft}$ for wells completed in the glacial deposits and from 0 to $3 \mathrm{ft}$ for wells completed in the Saginaw aquifer. Transient simulations with reduced recharge and increased pumping indicate a lowering of simulated water levels ranging from 0 to $6 \mathrm{ft}$ at observation-well locations and decreases in simulated streamflows ranging from 0.5 to $34.7 \mathrm{ft}^{3} / \mathrm{s}$ at streamflow-observation locations. Lowering of simulated water levels due to reduced recharge and increased pumping ranged from 0 to $6 \mathrm{ft}$ for wells completed in the glacial deposits and from 0 to $6 \mathrm{ft}$ for wells completed in the Saginaw aquifer. The reduction in the amount of water available to recharge the groundwater system affects the upper model layers representing the glacial aquifers more than the deeper bedrock layers. However, with a reduction in recharge and an increase in withdrawals from the bedrock aquifer, water levels in the bedrock layers are affected more than those in the glacial layers. Differences in water levels between simulations with reduced recharge only and those with reduced recharge and increased pumping are greatest in the Lansing area and smallest away from pumping centers, as expected. Additionally, the increases in pumping rates had minimal effect on most simulated streamflows, with the largest differences in the Lansing area. For both transient simulations, model input variables at the end of year 6 were specified such that water movement into storage would approximately equal water movement out of storage. With the increase in pumping rates, less water is available to discharge to the streams or enter storage, and more water is removed from streams and storage. With reduced recharge after 2 years (during year 8), water movement into storage was about half of water movement out of storage; in year 8 with reduced recharge and increased pumping, water movement into storage was also nearly half that of water movement out of storage (fig. 15). During year 6 , water was removed from storage mostly during the summer and fall, from July to November, and water entered storage from December to June, although primarily from March to May. After 2 years of reduced recharge and reduced recharge with increased pumping, water entered storage from December to May, and water moved out of storage from June to

Table 5. Transient model details for monthly stress periods for the Tri-County region, Michigan.

[Mgal/d, million gallons per day]

\begin{tabular}{lccc}
\hline \multirow{2}{*}{$\begin{array}{l}\text { Time interval represented } \\
\text { by stress period }\end{array}$} & $\begin{array}{c}\text { Stress period length } \\
\text { (days) }\end{array}$ & \multicolumn{2}{c}{ Simulated pumping } \\
\cline { 3 - 4 } & 31 & $\mathbf{2 0 0 5}$ (Mgal/d) & Future (Mgal/d) \\
\hline January & 28 & 38.4 & 45.8 \\
February & 31 & 41.9 & 42.0 \\
March & 30 & 40.9 & 47.1 \\
April & 31 & 43.1 & 45.7 \\
May & 30 & 49.7 & 48.6 \\
June & 31 & 48.6 & 55.9 \\
July & 31 & 51.0 & 55.6 \\
August & 30 & 51.3 & 57.7 \\
September & 31 & 42.2 & 56.6 \\
October & 30 & 40.1 & 46.8 \\
November & 31 & 36.3 & 44.6 \\
December & & & 40.5 \\
\hline
\end{tabular}


November (fig. 16). The differences observed between year 6 and year 8 in each simulation would possibly be different if the model had not been run for 6 years so that water movement into storage would approximately equal water movement out of storage.

\section{Delineation of Contributing Areas}

The particle-tracking program MODPATH (Pollock, 1989) can be combined with MODFLOW-calculated flow in each cell to determine the areas of the water table, projected up to the land surface, where water that is discharged by a well enters the groundwater-flow system. Particle tracking simulates the advective movement of groundwater, so the effects of diffusion, dispersion, and chemical reactions are not considered. Therefore, particle tracking is not intended as a substitute for simulating the transport of dissolved chemicals in the groundwater-flow system. An estimated porosity of 15 percent was previously used for particle-tracking simulations (Holtschlag and others, 1996) and, in the absence of any additional information, was used for all layers in the 2009 model.

Groundwater-flow paths, and, thus, particle-tracking results, depend in part on the stresses to the groundwater-flow system. Different pumping rates or pumping locations will change the groundwater-flow patterns in the modeled area and result in different zones of contribution and areas contributing recharge to the pumping wells. The area contributing recharge to a pumping well is defined as the surface area of the three-dimensional boundary of the groundwater-flow system that delineates the location of the water entering the groundwater-flow system that eventually flows to the well and discharges (Reilly and Pollock, 1993). The zone of contribution to a pumping well is defined as the three-dimensional volumetric part of the aquifer through which groundwater flows to a pumping well from the area contributing recharge (Morrissey, 1989). A wellhead-contributing area for each pumping well is defined here as the combination of areal extent of the areas contributing recharge and of the zones of contribution projected up to the land surface. By tracking particles for a specified amount of time, such as 10 years, time-oftravel areas can be determined. Under steady-state conditions, the water discharging from a pumped well is a blend of water of different ages or traveltimes. In each specified time-oftravel simulation, it is assumed that model pumping rates and pumping locations remain constant indefinitely and that the water withdrawn by each simulated well may represent water that has entered as recharge or that already was in the zone of contribution when the well began pumping.

A total of 38,700 hypothetical particles were placed on the sides of the cells containing selected Lansing-area production wells. These particles were tracked backward using the steady-state model along flow paths through the groundwaterflow field until they reached a top cell face in the upper model layer or until a specified amount of time elapsed. The position of the particle at the end of the simulation represents the location at the water table where the particle enters the groundwater-flow system or the location where water would flow to the well in the specified amount of time. Groundwater

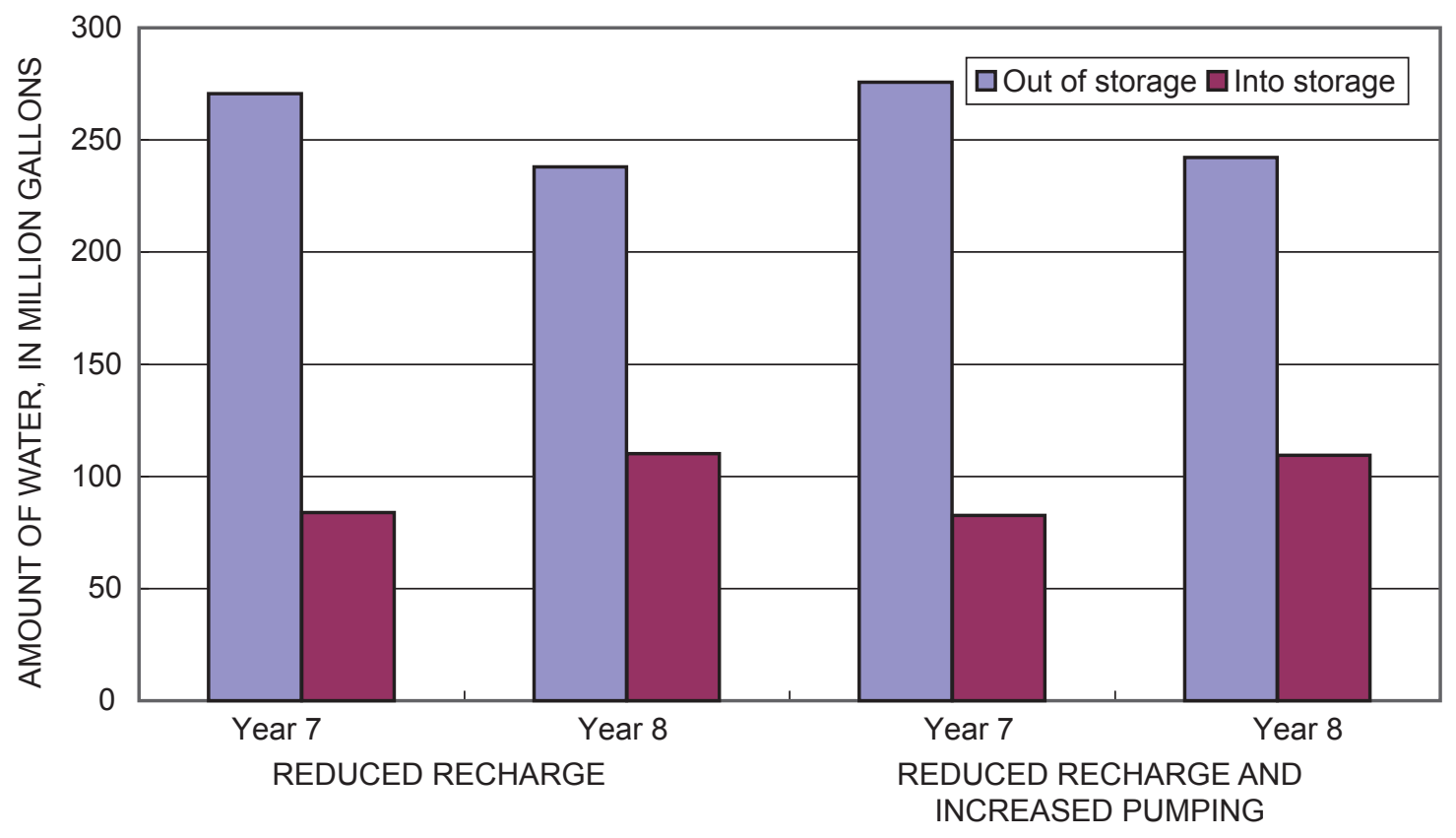

Figure 15. Net storage, by year, during transient simulations with reduced recharge and reduced recharge with increased pumping. 


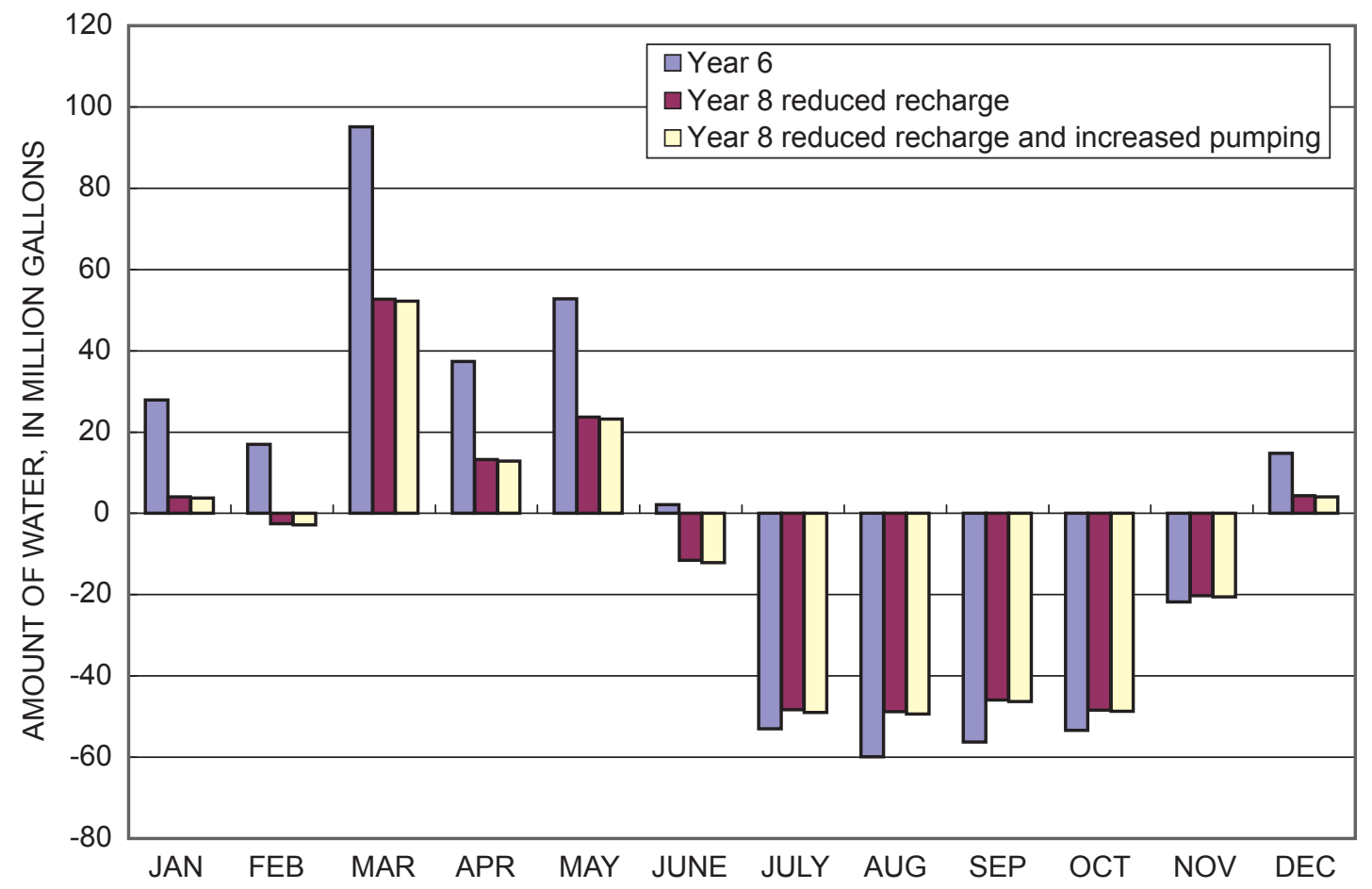

Figure 16. Net storage, by month, during transient simulations with reduced recharge and reduced recharge with increased pumping.

withdrawals of 45.3 Mgal/d representing 2006-7 conditions were specified for this simulation. Because 2007 was a somewhat dry year, contributing areas were delineated at a time with slightly higher pumping rates than would have been achieved using 2005 or 2006 pumping rates. Areas contributing recharge as well as zones of contribution were determined for 10, 20, and 40 years using the 2009 model. The areal extent of the 10-year time-of-travel wellhead-contributing areas encompasses about $29 \mathrm{mi}^{2}$ (fig. 17). The areal extent of the 20-year time-of-travel areas encompasses about $41 \mathrm{mi}^{2}$, and the areal extent of the 40-year time-of-travel areas encompasses about $59 \mathrm{mi}^{2}$.

\section{Optimization Scenarios}

Simulation results and contributing areas described above are based on flow directions resulting from the withdrawal rates specified in the model input files. Different withdrawal locations and pumping rates must be specified for each simulation to illustrate different flow patterns. Optimization of groundwater withdrawals with a water-resource management model allows determination of withdrawal locations and pumping rates that best meet a specified management objective and series of constraints; such constraints could include water-treatment costs and (or) water-quality or water-quantity requirements. For example, well locations and pumping rates could be selected to maximize pumpage or to minimize operational or treatment costs. The groundwater-management program GWM (Ahlfeld and others, 2005) can be combined with MODFLOW-calculated water levels by using a responsematrix approach to solve several types of groundwater-management formulations. Each management formulation consists of a set of decision variables, an objective function, and a set of constraints. The objective function can be specified to minimize or maximize the sum of some or all the specified decision variables, subject to a set of specified constraints. These decision variables can be flow-rate decision variables, which specify withdrawal rates at wells, or binary variables, which define the status of the flow-rate decision variables. Constraints can specify upper and lower bounds on the flowrate decision variables; summation of the decision variables; or hydraulic-head drawdowns, differences, or gradients. In this study, the optimization formulations were solved by using linear programming (LP), in which the objective function and all constraints are linear functions of the decision variables. The water level at each constraint location is equal to the sum of the water level at the constraint location for a base withdrawal condition plus the sum of the water-level changes that result from changes in withdrawal rates at each site. The response coefficients, which describe this change in the groundwater levels resulting from stresses at each withdrawal location, are assumed to be constant for linear systems (that is, they do not vary with changes in the distribution of withdrawal rates throughout the groundwater-flow system) (Ahlfield and others, 2005). 


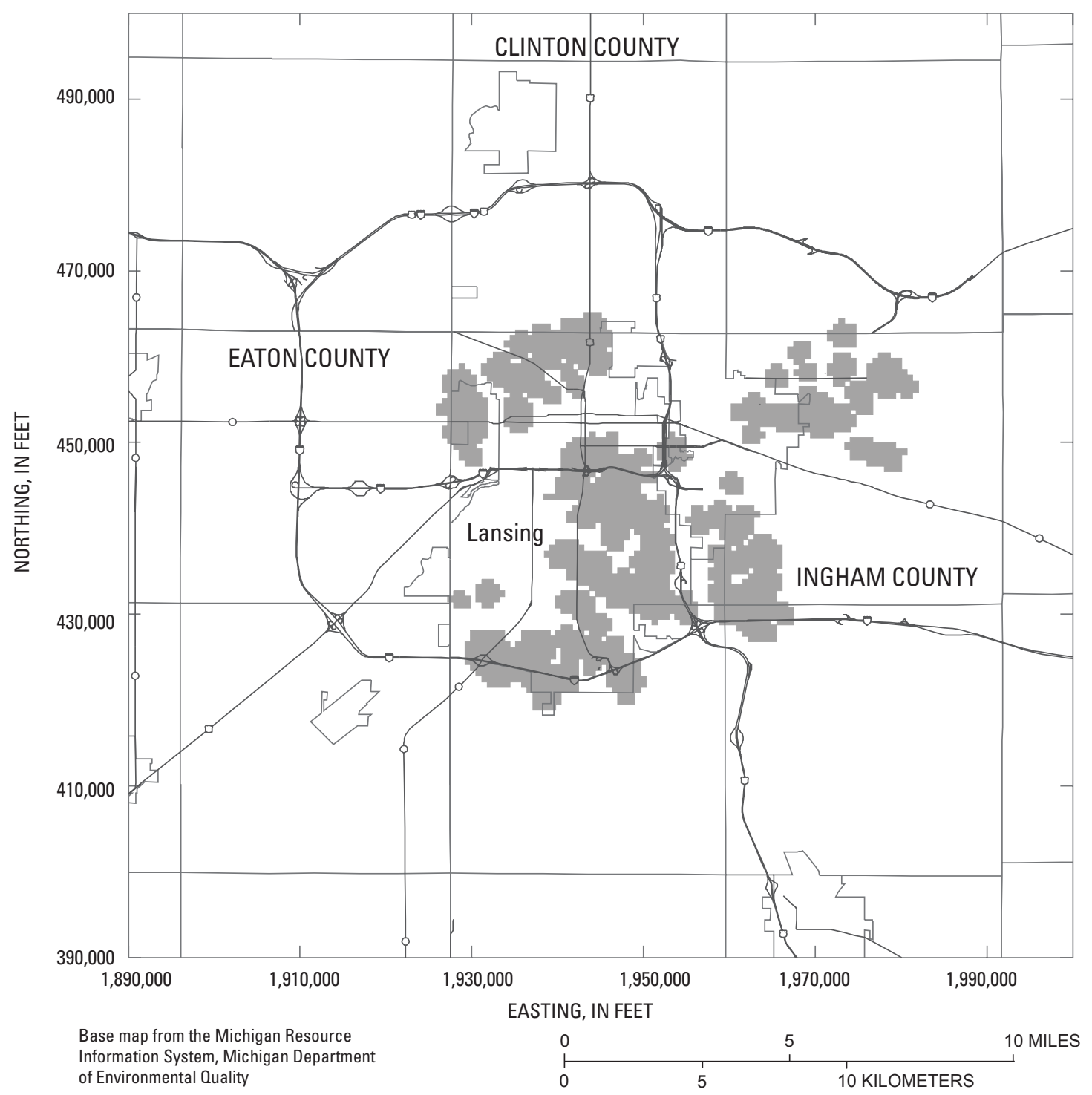

Figure 17. Simulated 10-year time-of-travel areas for selected production wells in the nine-township area, Tri-County region, Michigan.

For this study, optimization was used with existing production wells to determine the additional capacity available from selected wells with low operational costs; it was also used with proposed new locations to determine withdrawal locations to achieve desired additional withdrawal capacity while meeting specified head constraints. In each optimization scenario, some wells are managed (where pumping rates can be optimized) and some wells are unmanaged (where pumping rates are specified and are not optimized during the simulation). Of the existing production wells in the Lansing area, 78 were selected for optimization on the basis of operational costs and pumping history; that is, wells with relatively lower costs and higher current pumping rates were selected to be managed, and more infrequently used wells with higher costs were left unmanaged. Operational costs were based primarily on water-treatment expenses because the cost to soften water is much greater than the cost of electricity to operate the well (William Maier, LBWL, oral commun., 2007). In a first set of optimization scenarios (scenarios L1, L2, LS1, LS2; table 6), relative (that is, not actual) operational costs were used to determine pumping rates at the managed existing well locations. In a second set of optimization scenarios (scenarios $\mathrm{A} 1, \mathrm{~A} 2, \mathrm{~B} 1$, and $\mathrm{B} 2$; table 6), existing production wells were unmanaged (such that pumping rates remained fixed at 2007 rates) and proposed new wells were specified as managed. Two potential locations for additional wellfield capacity were selected for the second set of optimization scenarios. Area A south of Lansing in Delhi Township was specified to have 30 wells, and area B north of Lansing in Dewitt Township was specified to have 35 wells. Each well was open vertically 
Table 6. Summary of optimization formulations and results for the Tri-County region, Michigan.

\begin{tabular}{lcccc}
\hline Scenario & $\begin{array}{c}\text { Number of } \\
\text { managed wells }\end{array}$ & $\begin{array}{c}\text { Number of } \\
\text { head constraints }\end{array}$ & $\begin{array}{c}\text { Upper bound on } \\
\text { pumping rates } \\
\text { (in million } \\
\text { gallons per day) }\end{array}$ & $\begin{array}{c}\text { Additional } \\
\text { capacity }\end{array}$ \\
\hline L1 & 78 & 103 & Varies & 6.11 \\
L2 & 78 & 103 & 1 & 14.13 \\
LS1 & 78 & 103 & Varies & 5.72 \\
LS2 & 78 & 103 & Varies & 5.66 \\
A1 & 30 & 1 & 0.5 & 7.98 \\
A2 & 30 & 1 & 1 & 9.54 \\
B1 & 35 & 37 & .5 & 12 \\
B2 & 35 & 37 & 1 & 12 \\
\hline
\end{tabular}

to layers 5 through 10 , and each occupied an individual cell with four to six cells between each well. Both areas had two optimization simulations, one for each maximum pumping rate of 0.5 and $1 \mathrm{Mgal} / \mathrm{d}$, to determine whether a total combined pumpage of $12 \mathrm{Mgal} / \mathrm{d}$ could be achieved. Head constraints were specified in both sets of scenarios to limit dewatering of the glacial deposits and to prevent water levels in the upper bedrock aquifer unit from falling below the top of the unit. For each optimization scenario, withdrawals from unmanaged wells were simulated with the WEL package. Wells previously simulated with the MNW package were converted to the WEL package, with withdrawals distributed among layers on the basis of rates determined by the MNW package. This conversion was necessary because the multiple-layer representation in the MNW package accounts for water-level differences between multiple producing zones. These water-level differences between aquifers can induce cross-flow between aquifers even when there is no discharge from a well or even under pumping conditions (Halford and Hanson, 2002). Therefore, specifying withdrawals only with the WEL package means that all withdrawals are specified as a discharge of water from each cell. Water levels in the lowest glacial unit (layer 3 ) and the upper sandstone unit (layer 5) were compared from simulations with wells represented by the MNW and WEL packages. The majority of differences were less than $1 \mathrm{ft}$ in layer 3 and less than $0.5 \mathrm{ft}$ in layer 5; therefore, discharge (well withdrawal) rates were adequately represented with the WEL package in the optimization scenarios. Simulations were done with the steady-state model in order to represent the potential long-term impacts of the optimized pumping results.

In the first optimization scenario (L1), existing (2007) pumpage from the managed wells totaled $25.65 \mathrm{Mgal} / \mathrm{d}$, and pumpage from the unmanaged wells totaled $19.65 \mathrm{Mgal} / \mathrm{d}$. Managed wells withdrew water from the bedrock units, whereas unmanaged wells were in both the glacial and bedrock units. Because the simulation was specified to maximize total pumpage, coefficients in the objective function for each managed well were assigned values that reflected the relative inverse operational cost of each well; that is, wells with relatively low operational costs were given higher weights (coefficient values) and those with relatively high operational costs were given lower weights. The wells were divided into four groups and assigned relative weights equal to $1.1,1.2,1.3$, or 1.4. Therefore, wells with higher costs (and a coefficient of 1.1) would contribute less to the objective function, and wells with lower costs (and a coefficient of 1.4) would contribute more. Maximum total pumpage from all managed wells was based on water-treatment capacities and specified to be 50 $\mathrm{Mgal} / \mathrm{d}$. A total of 103 head constraints were used to limit water-level declines, with 57 in the lower glacial unit (layer 3 ) and 46 in the upper bedrock unit (layer 5). These head constraints were specified to be the minimum of $5 \mathrm{ft}$ above the bottom of layer 3 or $4 \mathrm{ft}$ above the water level in layer 5 under steady-state 2007 pumping conditions. In some cases, the 2007 pumping rates indicated that water levels would be below the bottom of layer 3 , so these head constraints were specified so that the optimized pumping would prevent any additional water-level decline beyond that with existing pumping rates. It is important to remember that the steady-state model represents the long-term effects of the specified groundwater withdrawals with every well pumping continuously; so the fact that part of the glacial deposits are dry as a result of the groundwater withdrawals does not necessarily represent the actual conditions in the area with wells pumping intermittently at varying rates during the year. Transient simulations would be needed to better represent potential impacts of varying pumping rates.

The optimal total withdrawal rate for this management formulation (L1) is $31.76 \mathrm{Mgal} / \mathrm{d}$, with 67 managed wells pumping (fig. 18). The optimization results indicate that an additional $6.11 \mathrm{Mgal} / \mathrm{d}$ could be withdrawn above the 2007 pumping levels, given the specified formulation and constraints (table 6). Six wells that pumped water in 2007 did not withdraw water under the optimized conditions, whereas four wells that did not pump water in 2007 did withdraw water under the optimized conditions. Changing these constraints, 


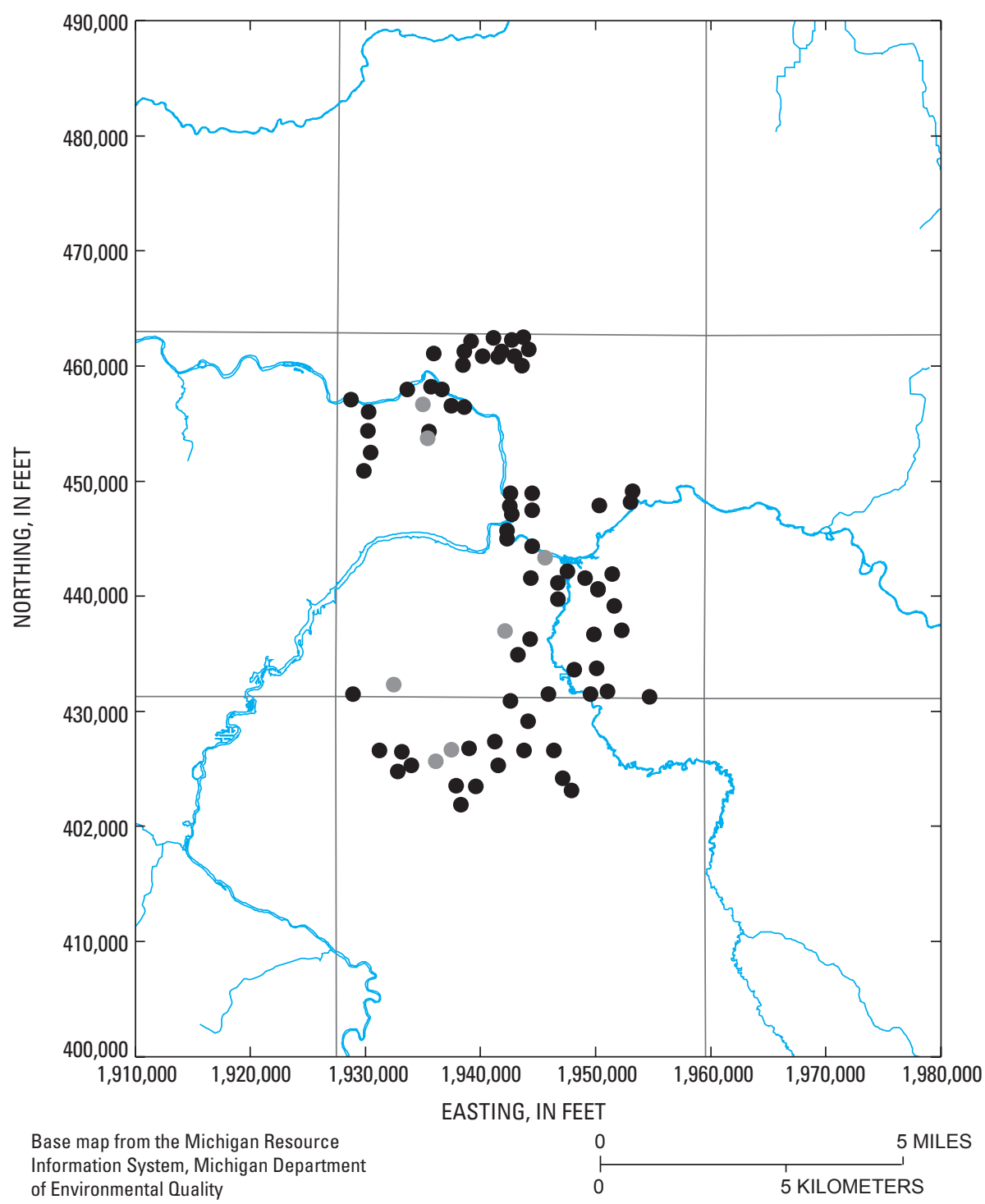

\section{EXPLANATION}

- Well selected for withdrawals

- Well not selected for withdrawals

Figure 18. Optimized wells in the Lansing area, Michigan.

such as including different wells or changing the maximum pumping rate for each well location, would possibly yield different optimized pumping rates. Also, it is important to note that these steady-state scenarios are based on the assumption of constant pumping throughout the year; therefore additional pumping capacity might be possible with wells pumping at intermittent rates during the year. In the post-optimization analysis with the model running the optimized pumping rates, 12 of the head constraints were not met ( 3 of the cells were dry), indicating that water levels in those cells were below the specified value (with the largest difference being $3.2 \mathrm{ft}$ ). The fact that some constraints were not met with the model simulating the optimized pumping rates is mostly a reflection of (1) the ability of the model-calculated response coefficients to accurately reflect the response of the simulated groundwater system to changes in stress-which, in turn, depends on the accuracy of the MODFLOW-calculated heads - and (2) the assumption that heads respond linearly to changes in the stress rates imposed at the flow-rate decision variables. However, the maximum difference of $3.2 \mathrm{ft}$ in the value of the head constraint is considered acceptable for the goals of this study given the uncertainties in the understanding of the hydrogeologic system and in the true values of the model input parameters.

To investigate whether additional capacity might be available if pumping rates at managed wells were allowed to 
increase above the maximum rates specified for $\mathrm{L} 1$, an additional scenario was done in which the maximum rate for each well was set to $1.0 \mathrm{Mgal} / \mathrm{d}$. Head constraints were the same as those described above for L1. The optimal total withdrawal rate for management formulation (L2) is $39.77 \mathrm{Mgal} / \mathrm{d}$, with 46 managed wells pumping. The optimization results indicate that an additional $14.13 \mathrm{Mgal} / \mathrm{d}$ could be withdrawn above the 2007 pumping levels (table 6), given the specified formulation and constraints. In the post-optimization analysis with the model running the optimized pumping rates, 29 of the head constraints were not met ( 10 of the cells were dry), indicating that water levels in those cells were below the specified value. Even though the specified maximum pumping rates were not feasible for each managed well, this scenario indicates that additional capacity might be available in some parts of the Lansing area, especially considering that this simulation was done with the steady-state model representing long-term continuous pumping and, realistically, each well pumps intermittently during the year (usually at less than the maximum rate).

Several scenarios were done to test the sensitivity of the optimization results to the relative weights specified for the operational costs of each managed well. Two additional scenarios were done with different weights for the managed wells in the Lansing area; relative weights of 1.0, 1.5, 2.0, and 2.5 were used for management formulation LS1, and relative weights of $0.2,0.4,0.6$, and 0.8 were used for management formulation LS2. Head constraints for each management scenario were the same as those described above for L1. The optimal total withdrawal rate for management formulation (LS1) is $31.37 \mathrm{Mgal} / \mathrm{d}$, with 69 managed wells pumping. The optimization results indicate that an additional $5.72 \mathrm{Mgal} / \mathrm{d}$ could be withdrawn above the 2007 pumping levels (table 6), given the specified formulation and constraints. In the postoptimization analysis with the model running the optimized rates, 11 of the head constraints were not met ( 3 of the cells were dry), indicating that water levels in those cells were below the specified value. The optimal total withdrawal rate for management formulation (LS2) is $31.31 \mathrm{Mgal} / \mathrm{d}$, with 69 managed wells pumping. The optimization results indicate that an additional $5.66 \mathrm{Mgal} / \mathrm{d}$ could be withdrawn above the 2007 pumping levels (table 6), given the specified formulation and constraints. In the post-optimization analysis with the model running the optimized rates, 11 of the head constraints were not met ( 3 of the cells were dry), indicating that water levels in those cells were below the specified value. Thus, varying the weights used for the managed wells during the solution of the optimization formulations resulted in about the same additional capacity above the 2007 pumping rates under steady-state conditions.

In the next set of optimization scenarios with the proposed new wells in areas A and B, pumpage from the unmanaged wells totaled $45.3 \mathrm{Mgal} / \mathrm{d}$ under 2007 conditions. Managed wells withdrew water from the bedrock units, whereas unmanaged wells were in both the glacial and bedrock units. The scenarios were done to determine whether some combination of the wells in each area could be pumped to achieve a maximum total pumping rate of $12 \mathrm{Mgal} / \mathrm{d}$, with a maximum pumping rate for each well of $0.5 \mathrm{Mgal} / \mathrm{d}$ in scenarios $\mathrm{A} 1$ and $\mathrm{B} 1$ and of $1.0 \mathrm{Mgal} / \mathrm{d}$ in scenarios A2 and B2. Each proposed well location was treated the same, with coefficients in the objective function for each managed well set to 1. In area A, one head-constraint location in layer 3 was sufficient to limit water-level declines, whereas in area B, 37 head-constraint locations in layer 5 were necessary. With a maximum pumping rate of $0.5 \mathrm{Mgal} / \mathrm{d}$ for each well, the optimization model indicates that $7.98 \mathrm{Mgal} / \mathrm{d}$ could be achieved using 16 wells in area A and $12 \mathrm{Mgal} / \mathrm{d}$ could be achieved using 24 wells in area $\mathrm{B}$ (fig. 19; table 6). With a maximum pumping rate of $1.0 \mathrm{Mgal} / \mathrm{d}$ for each well, optimization indicates that $9.54 \mathrm{Mgal} / \mathrm{d}$ could be achieved using 10 wells in area $\mathrm{A}$ and $12 \mathrm{Mgal} / \mathrm{d}$ could be achieved using 13 wells in area B (fig. 20; table 6). Withdrawals from area $\mathrm{B}$ did not produce the same rate of decline in layer 3 as did the withdrawals from wells in area A. Areas A and B differ in the specified vertical hydraulic characteristics of layer 4 , which is the shale unit between the lower glacial unit and the upper bedrock unit. The vertical leakance is higher in area A, indicating more connection between the glacial and bedrocks units in area $\mathrm{A}$ than in area B. However, more site-specific information would be needed to determine whether this difference really exists, because the hydraulic properties were determined for these areas by using wells some distance away (very few local wells are in the area). In the post-optimization analysis with the model running the optimized pumping rates for area $\mathrm{A}$ with a maximum rate of $0.5 \mathrm{Mgal} / \mathrm{d}$ per well, one head constraint was not met, indicating that water levels in that cell were $0.7 \mathrm{ft}$ below the specified value; similarly, with a maximum pumping rate of $1.0 \mathrm{Mgal} / \mathrm{d}$, one head constraint was not met, indicating that water levels in that cell were $0.7 \mathrm{ft}$ below the specified value. In the post-optimization analysis with the model running the optimized pumping rates for area $\mathrm{B}$ with a maximum rate of $0.5 \mathrm{Mgal} / \mathrm{d}$ per well, all constraints were met; with a maximum pumping rate of $1.0 \mathrm{Mgal} / \mathrm{d}$, one head constraint was not met, indicating that water levels in that cell were $1.5 \mathrm{ft}$ below the specified value. In both cases, these small differences do not indicate that the constraint locations would be dry. And, as with the previous scenarios, these steady-state simulations are based on the assumption that wells pump continuously throughout the year.

\section{Model Assumptions and Limitations}

The groundwater-flow model was developed to simulate the regional groundwater-flow system in the Tri-County region. Hydraulic properties represented in each layer were assumed to be horizontally isotropic; that is, within a cell, hydraulic properties are the same in the north-south direction as in the east-west direction. Hydraulic properties do vary from location to location; however, each grid cell represents the average hydraulic properties in the volume of aquifer 


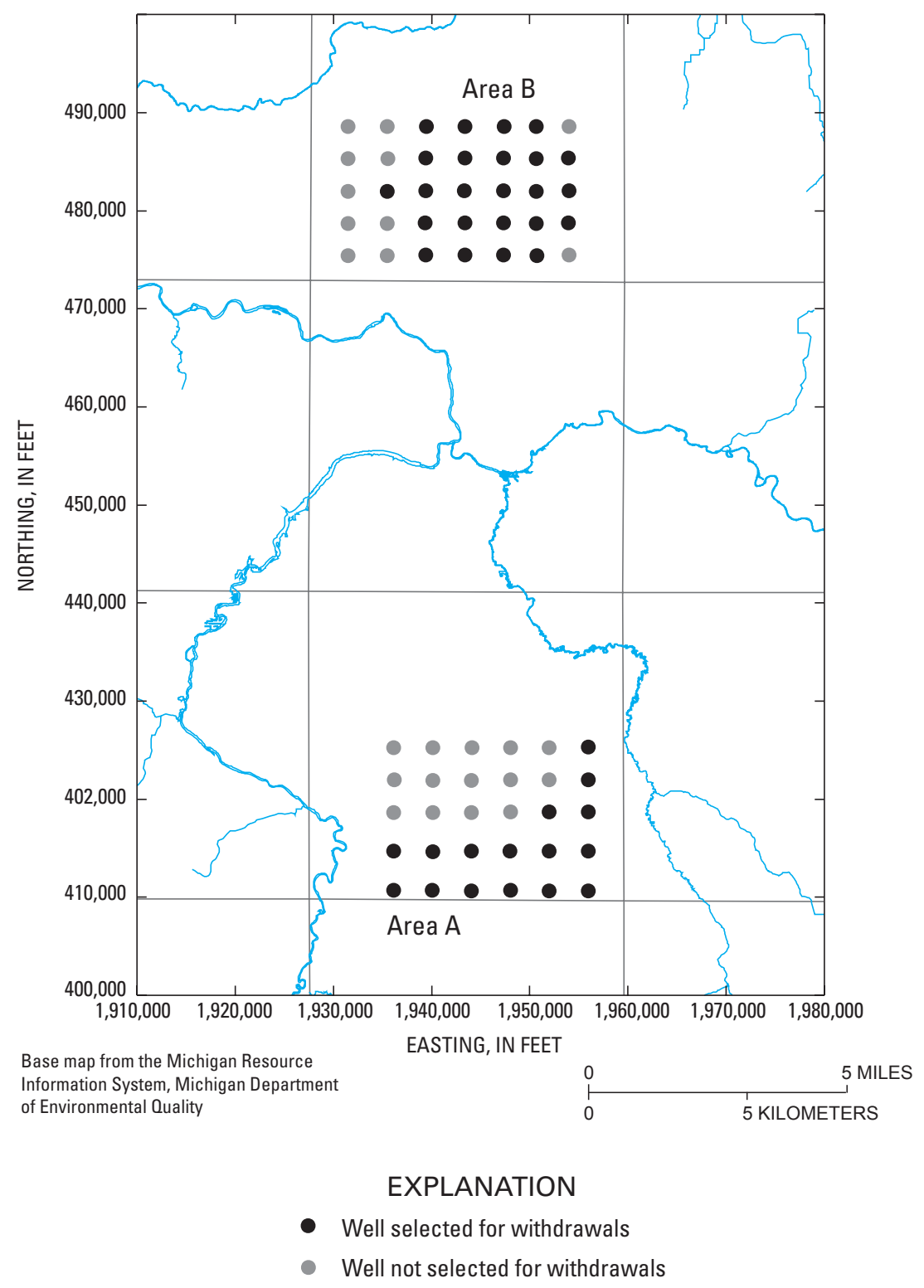

Figure 19. Optimized wells for areas $A$ and $B$ with a specified maximum pumping rate of 0.5 million gallons per day.

represented by the cell. Vertical variations in aquifer properties within layers and any variations in head or flow within each layer are not simulated in the model. Local flows over distances smaller than the dimensions of the grid cell also cannot be accurately simulated. Additional geologic and hydrologic data, as well as finer discretization of the model, would be needed to simulate flow systems in smaller areas. The accuracy of layer surfaces and hydraulic conductivity estimates are limited by the available data at well and boring locations. Additional control and accuracy could be achieved by inclusion of more data points.
It is assumed in steady-state model simulations that all stresses to the system, including well withdrawals and recharge rates, remain constant throughout the simulation. No net gain or loss of flow is simulated in the system; that is, in the model budget, water entering the model approximately equals water leaving the model, and no changes in groundwater storage result. It is assumed in the transient simulations that the storage characteristics of each aquifer can be represented by average values of either the storage coefficient or specific yield that are uniform within each layer. The actual storage properties of the aquifers likely differ from location to location. It is assumed in transient simulations that generalized 


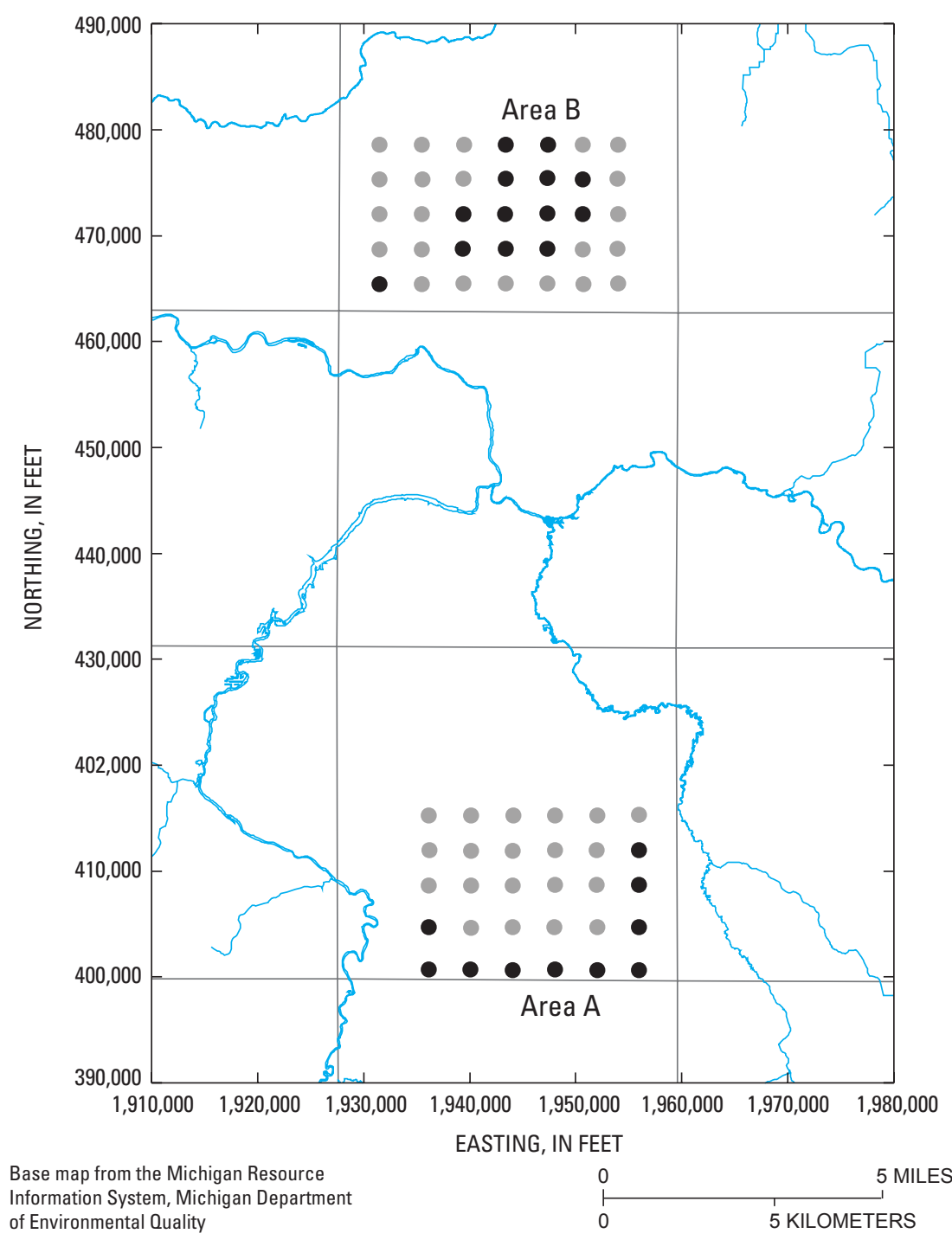

EXPLANATION

- Well selected for withdrawals

- Well not selected for withdrawals

Figure 20. Optimized wells for areas $A$ and $B$ with a specified maximum pumping rate of 1 million gallons per day.

values of annual and monthly recharge rates vary on the basis of available precipitation and estimated base-flow data. Actual annual and monthly recharge rates were not measured and may vary both regionally and locally from those used in transient simulations. Estimates of reduced recharge due to impervious areas were generalized because of a lack of site-specific information; furthermore, areas represented as urban in the model simulation were based on interpretation of aerial photos and were limited by the model cell size (for example, actual urban areas, and thus impervious areas, may be larger or smaller than those observed). Therefore, effects due to urbanization would require more detailed study to determine which urban areas actually reduce recharge, and to what extent. Further investigation also would be needed to better determine the potential effects of any reductions in recharge on water levels in this area. Any reductions in recharge that may be caused by tiled agricultural fields were not considered in these simulations. Estimates of reduced recharge to represent low rainfall/ drought conditions were based on observed variations in annual precipitation data and not on actual drought-condition data. Therefore, for this study "drought" was taken to mean a time of water shortage, and model results may differ from conditions observed during an actual period defined as a drought. 
Small withdrawals from domestic wells were not included because of the difficulty in obtaining reliable data and the limitations in representing small-scale flow systems (systems considerably smaller than simulated as part of this study). However, domestic groundwater withdrawals probably are small at the scale of the model.

Streams and lakes are represented in the model as river cells. This type of boundary condition allows for the determination of the amount of flow to and from the river cell; however, the amount of water flowing into the cell from an upstream cell is not accounted for. Therefore, a river cell could lose more water than actually is flowing in the stream. Thus, for detailed analysis of flow within particular streams, an accounting of actual flow within the stream needs to be part of the simulation, but such an accounting was not done for this study.

The base of the model is assumed to be impermeable. External boundary conditions, which are based on natural hydrologic conditions and are distant from the Tri-County region well fields, are assumed to have minimal effect on water levels and flow in the interior of the model. The model may not accurately represent the groundwater-flow system for any predictive simulations involving groundwater withdrawals near the model boundaries.

The location and size of the areas contributing recharge to wells are affected by the hydrogeologic characteristics and boundary conditions of the groundwater-flow system, as well as the location, depth, and discharge rate of each simulated well. Thus, the simulated areal extent of the areas contributing recharge and zones of contribution are dependent on the estimated values for the hydraulic characteristics, such as transmissivity and riverbed conductance, and on the pumping rates of the individual wells. With annual or seasonal variations in pumping rates or pumping locations, the size of areas contributing recharge could change. In addition, areas contributing recharge could change in size or location with changes in recharge rates or in the way the groundwater-flow system is represented.

The accuracy of particle-tracking simulations is limited by the accuracy of the numerical model on which the simulations are based, the estimates of the effective porosity of the flow system, and the accuracy of the cell flow velocities in approximating the local groundwater-flow velocities. Actual effective porosity may differ from location to location and from layer to layer. The particle-tracking program considers groundwater flow by advection only. If the effects of dispersion were included, the areas contributing recharge could be larger. Because flow through fractures is not explicitly simulated in the model, groundwater flow and traveltimes in fractured bedrock, if present, may not be represented accurately.

The accuracy of optimization scenarios depends on the precision of the response coefficients, which is limited by the accuracy of the water levels calculated by MODFLOW for the numerical model of the hydrologic system. The accuracy also is limited by the approximation of the groundwater-flow equations (Ahlfield and others, 2005). The accuracy of the numerical model depends on the representation of the flowsystem characteristics, including the geologic framework, hydraulic properties, and boundary conditions. The error in the MODFLOW solution for the groundwater-flow equations is proportional to the size of the grid cells and the length of the transient time steps; this error can be decreased with smaller grid cells and shorter time steps. During optimization, the response coefficients are used by GWM to predict the pumping rates given the specified head constraints; however, some head constraints were not met with the model running the optimized pumping rates. This may be explained by the inaccuracies or approximations noted above or by potential nonlinearities in the system that resulted in a nonlinear response of heads to changes in withdrawal rates. Solution of the management formulations with linear programming (LP) may be inappropriate if the management problem has a significant nonlinear response. The presence of water-table conditions and head-dependent boundary conditions can create nonlinear relations between groundwater heads and flow rates to or from the simulated boundary; therefore, use of sequential linear programming (SLP) may be more appropriate for these simulations and may improve the accuracy and precision of the response coefficients. However, the maximum difference of $3.2 \mathrm{ft}$ in the value of the head constraint is considered acceptable for the goals of this study given the uncertainties in the understanding of the hydrogeologic system and in the true values of the model input parameters. Representation of withdrawals from wells with the WEL package for optimization scenarios was based on the apportionment of water from or between well cells that was determined by using the MNW package during transient model simulations. So, this representation with the WEL package is based on the assumption that this apportionment would not change in response to the pumping configurations resulting from the optimization scenarios.

\section{Summary and Conclusions}

A previously constructed groundwater-flow model of the Saginaw aquifer was refined in order to better represent the regional hydrologic system in the Tri-County region, which consists of Clinton, Eaton, and Ingham Counties, Michigan. The Saginaw aquifer, which is in the Grand River and Saginaw Formations of Pennsylvanian age, is the primary source of groundwater for Tri-County residents. With increasing demand, the need to manage withdrawals from the Saginaw aquifer has become more important, and the existing 1996 model could not adequately address these issues of water quality and quantity. New information was needed to better address potential effects on water resources due to drought, locally high water demands, changes in pumping due to environmental conditions, inhibition of recharge by impervious surfaces, and issues affecting water quality, such as contaminant sources. In 2004, the Lansing-area communities working with the Tri-County Regional Planning Commission and the 
U.S. Geological Survey began a long-term plan for continued refinement of the regional groundwater-flow model. The refined groundwater-flow model allows simulations to address these issues of water quantity and provides communities with a tool that will enable them to better plan for expansion and subsequent protection of their groundwater-supply systems.

The 1996 Tri-County regional groundwater-flow model, developed for Clinton, Eaton, and Ingham Counties, has been used in the past by local water managers to answer questions about protection and availability of their groundwater resources and to delineate contributing areas for local Wellhead Protection Programs. Refinements in 1997 and 2003 enabled the model to better represent flow within the ninetownship area surrounding Lansing and within the Mason and Vevay Township area. Refinements for the 2009 version of the model included representation of the system under steady-state and transient conditions, adjustments to the estimated regional groundwater recharge rates to account for both temporal and spatial differences, and adjustments to the representation and hydraulic characteristics of the glacial deposits and Saginaw Formation. The 1996 model consisted of two layers; the upper layer represented aquifers in the glacial deposits and the lower layer represented the Saginaw aquifer. The refined 2009 model consists of 10 layers; the upper 3 layers represent aquifers in the glacial deposits and the remaining 7 layers represent the multiple bedrock system units (sandstones, interbedded series, and shale units). This division of the groundwater-flow system into additional layers permits better representation of flow, interconnection between the glacial and bedrock aquifers, and individual production wells to be better characterized. The 1996 model simulated groundwater flow under steady-state conditions. Average recharge rates representing the spatial variation over the model area were calculated for the 1996 model. The refined 2009 model was calibrated to both steadystate and transient conditions; therefore, recharge rates and groundwater withdrawals could both change during the simulation. For the 2009 model, part of the southern boundary was extended beyond that modeled in the 1996 model to permit simulations in the Eaton Rapids and Eaton Rapids Township area. The transient model consists of an initial steady-state stress period representing predevelopment conditions and 16 subsequent stress periods representing time intervals from the early 1900 s up to 2005 . A separate transient model was developed to simulate monthly changes in recharge and groundwater withdrawals based on recent data. This model was run under the same conditions for 6 years in order for the change in storage to become minimal so that effects after several years of withdrawals could be determined. The temporal variation in recharge rates for the transient model was based on an analysis of historical precipitation data. Estimated recharge rates for the transient model stress periods were varied on the basis of the percentage change from the average precipitation rate for each time interval. For the monthly stress periods, estimated recharge rates were varied on the basis of the calculated average base-flow values for 2003-5. Under steady-state conditions, groundwater withdrawals totaled $42.6 \mathrm{Mgal} / \mathrm{d}$. Under transient conditions, groundwater withdrawal rates were varied according to estimated or measured pumping rates and ranged from $3.6 \mathrm{Mgal} / \mathrm{d}$ in stress period 2 up to an annual withdrawal rate of $46.1 \mathrm{Mgal} / \mathrm{d}$ in stress period 17. Monthly withdrawals were highest from June to September and ranged from 36.3 $\mathrm{Mgal} / \mathrm{d}$ in December to $51.3 \mathrm{Mgal} / \mathrm{d}$ in September. Simulations with the refined 2009 model included investigation of the potential effects of reduced recharge due to impervious areas or low rainfall/drought conditions, delineation of contributing areas with recent pumping rates, and optimization of pumping subject to various quantity and quality constraints.

Simulations investigating reduced recharge due to impervious areas were done under steady-state and transient conditions. Urban areas were determined from 1984, 1994, and 2003 aerial photos of the Tri-County region. Recharge was assumed to be reduced by 20 and 50 percent because of the impervious surfaces in these urban areas. In addition, recharge was reduced by 50 percent for an area around Lake Lansing to simulate the potential effects of rapid growth on water levels in this area. Steady-state simulation results indicate potential declines of as much as $2.2 \mathrm{ft}$ in the upper glacial unit (layer 1) and $1.7 \mathrm{ft}$ in the upper bedrock sandstone unit (layer 5) with a 20-percent reduction in recharge in urban areas. Steady-state simulation results indicate potential declines of as much as $6.2 \mathrm{ft}$ in the upper glacial unit (layer 1) and $4.1 \mathrm{ft}$ in the upper bedrock sandstone unit (layer 5) with a 50-percent reduction in recharge in urban areas. Steady-state simulation results indicate potential declines of less than $0.6 \mathrm{ft}$ in the upper glacial unit (layer 1) and less than $0.2 \mathrm{ft}$ in the upper bedrock sandstone unit (layer 5) with a 50-percent reduction in recharge for the area surrounding Lake Lansing. Transient simulation results indicate potential declines of as much as $1.2 \mathrm{ft}$ in the upper glacial unit (layer 1) and $1.1 \mathrm{ft}$ in the upper bedrock sandstone unit (layer 5) with a 20-percent reduction in recharge in urban areas. Transient simulation results indicate potential declines of as much as $3.1 \mathrm{ft}$ in the upper glacial unit (layer 1) and $2.7 \mathrm{ft}$ in the upper bedrock sandstone unit (layer 5) with a 50-percent reduction in recharge in urban areas. With a 50-percent reduction in recharge for the area surrounding Lake Lansing, transient simulation results indicate potential declines of less than $0.3 \mathrm{ft}$ in the upper glacial unit (layer 1) and less than $0.2 \mathrm{ft}$ in the upper bedrock sandstone unit (layer 5) .

Simulations investigating reduced recharge due to low rainfall and increased pumping to meet anticipated future demand were done with the transient model representing monthly conditions. Simulations with the transient model were done with 72 months (6 years) in which recharge and pumping reflected average recent conditions (as specified by the water-supply system) followed by 24 months ( 2 years) with modified recharge or modified recharge and pumping rates. Thus, at the beginning of the year with modified recharge and pumping rates, changes in storage were small (less than 2 percent) and water movement into storage approximately equaled water movement out of storage. During the final two simulation years, monthly recharge rates were reduced by about 30 
percent, and monthly withdrawal rates for Lansing-area production wells were increased by 15 percent. Transient simulations with reduced recharge indicate decreases in simulated water levels ranging from 0 to $6 \mathrm{ft}$ at observation locations and simulated flows ranging from 0.5 to $34.7 \mathrm{ft}^{3} / \mathrm{s}$ at observation locations. Decreases in simulated water levels due to reduced recharge ranged from 0 to $6 \mathrm{ft}$ for wells completed in the glacial deposits and from 0 to $3 \mathrm{ft}$ for wells completed in the Saginaw aquifer. Transient simulations with reduced recharge and increased pumping indicate decreases in simulated water levels ranging from 0 to $6 \mathrm{ft}$ at observation locations and simulated flows ranging from 0.5 to $34.7 \mathrm{ft}^{3} / \mathrm{s}$ at observation locations. Decreases in simulated water levels due to reduced recharge and increased pumping ranged from 0 to $6 \mathrm{ft}$ for wells completed in the glacial deposits and from 0 to $6 \mathrm{ft}$ for wells completed in the Saginaw aquifer. Differences in water levels and streamflows between simulations with reduced recharge and reduced recharge with increased pumping are greatest in the Lansing area and smallest away from pumping centers. During year 6, water was removed from storage mostly during the summer and fall, from July to November, and water entered storage the remaining months, although primarily from March to May. After 2 years of reduced recharge and reduced recharge with increased pumping, water entered storage from December to May, and water moved out of storage from June to November.

Wellhead-contributing areas (defined for this study as the combination of the areal extent of the areas contributing recharge and of the zones of contribution projected up to the land surface) were delineated for selected Tri-County-region production wells by using particle-tracking analysis. Groundwater withdrawals for 2006-7 totaled $45.3 \mathrm{Mgal} / \mathrm{d}$. Results of flow simulations indicate that 10-year time-of-travel areas cover approximately $29 \mathrm{mi}^{2}$. The areal extent of the 20 -year time-of-travel areas encompasses about $41 \mathrm{mi}^{2}$, and the areal extent of the 40-year time-of-travel areas encompasses about $59 \mathrm{mi}^{2}$. An estimate of effective porosity of 15 percent for the Saginaw and glacial aquifers was used in the computations.

Optimization of groundwater withdrawals with a waterresources management model allows incorporation of constraints on the groundwater-flow solution in order to optimize cost savings, water quality, and (or) water quantity. For this study, optimization was used with existing production wells to determine additional capacity while approximately accounting for operational costs; it was also used with proposed new locations to determine withdrawal locations to achieve the desired additional capacity while meeting specified head constraints. Of the existing production wells in the Lansing area, 78 were selected for optimization based on operational costs and pumping history and were used during the first set of optimization scenarios to determine pumping rates at the managed existing well locations. After optimization, pumpage totaled $31.76 \mathrm{Mgal} / \mathrm{d}$ with 67 managed wells pumping. Six wells that were previously pumping did not withdraw water under the optimized conditions, whereas four wells that were not pumping in 2007 did withdraw water under the optimized conditions. The optimization results indicate that an additional $6.11 \mathrm{Mgal} / \mathrm{d}$ could be withdrawn above the 2007 pumping levels, given the specified constraints. With modified maximum pumping rates of $1 \mathrm{Mgal} / \mathrm{d}$ for each managed well, an additional $14.13 \mathrm{Mgal} / \mathrm{d}$ could be withdrawn above the 2007 pumping levels, with 46 wells pumping. Changing these constraints, such as including different wells or changing the maximum pumping rate for each well location, would possibly yield different optimized pumping rates. Varying the coefficients for the managed Lansing-area wells used during the solution of the optimization formulation resulted in about the same additional capacity of between 5 and $6 \mathrm{Mgal} / \mathrm{d}$ above the 2007 pumping rates under steady-state conditions. In the second set of optimization scenarios, the existing production wells were unmanaged (so pumping rates remain fixed at 2007 rates) and proposed new wells were specified as managed. Two potential locations for additional wellfield capacity were selected for the optimization scenarios. Area A south of Lansing in Delhi Township was specified to have 30 wells, and area B north of Lansing in Dewitt Township was specified to have 35 wells. Two optimization simulations were run for each area, one for each maximum pumping rate of 0.5 and $1 \mathrm{Mgal} / \mathrm{d}$, to determine whether a total combined pumpage of $12 \mathrm{Mgal} / \mathrm{d}$ could be achieved in either area. With a maximum pumping rate of $0.5 \mathrm{Mgal} / \mathrm{d}$ for each well, optimization indicates that $7.98 \mathrm{Mgal} / \mathrm{d}$ could be achieved using 16 wells in area A and $12 \mathrm{Mgal} / \mathrm{d}$ could be achieved using 24 wells in area $\mathrm{B}$. With a maximum pumping rate of $1.0 \mathrm{Mgal} / \mathrm{d}$ for each well, optimization indicates that $9.54 \mathrm{Mgal} / \mathrm{d}$ could be achieved using 10 wells in area $\mathrm{A}$ and $12 \mathrm{Mgal} / \mathrm{d}$ could be achieved using 13 wells in area B. It is important to remember that the steady-state model used for each of these management scenarios represents the long-term effects of the specified groundwater withdrawals with every well pumping continuously; transient simulations would be needed to better represent potential impacts of varying intermittent pumping rates.

\section{References Cited}

Ahlfield, D.P., Barlow, P. M., and Mulligan, A.E., 2005, GWM-A groundwater management process for the U.S. Geological Survey modular groundwater model (MODFLOW-2000): U.S. Geological Survey Open-File Report 2005-1072, $124 \mathrm{p}$.

Anderson, M.P., and Woessner, W.W., 1992, Applied groundwater modeling - Simulation of flow and advective transport: San Diego, Calif., Academic Press, 381 p.

Baltusis, M.A., Quigley, M.F., and Mandle, R.J., 1992, Municipal ground-water development and withdrawals in the central lower peninsula of Michigan, 1870-1987: U.S. Geological Survey Open-File Report 91-215, 89 p. 
Cohee, G.V., Macha, Carol, and Holk, Margery, 1951, Thickness and lithology of Upper Devonian and Carboniferous rocks in Michigan: U.S. Geological Survey Oil and Gas Investigation Chart OC-41.

Eichenlaub, V.L., Harman, J.R., Nurnberger, F.V., and Stolle, H.J., 1990, The climatic atlas of Michigan: Notre Dame, Ind., University of Notre Dame Press, 165 p.

Freeze, R.A., and Cherry, J.A., 1979, Groundwater: Englewood Cliffs, N.J., Prentice-Hall, 604 p.

Halford, K.J., and Hanson, R.T., 2002, User guide for the drawdown-limited, multi-node well (MNW) package for the U.S. Geological Survey's modular three-dimensional finite-difference ground-water flow model, versions MODFLOW-96 and MODFLOW-2000: U.S. Geological Survey Open-File Report 02-293, 33 p.

Harbaugh, A.W., Banta, E. R., Hill, M.C., and McDonald, M.G., 2000, MODFLOW-2000, the U.S. Geological Survey modular ground-water model - User guide to modularization concepts and the ground-water flow process: U.S. Geological Survey Open-File Report 00-92, 121 p.

Hill, M.C., Banta, E.R., Harbaugh, A.W., and Anderman, E.R., 2000, MODFLOW-2000, the U.S. Geological Survey modular ground-water model- - User guide to the observation, sensitivity, and parameter-estimation processes and three post-processing programs: U.S. Geological Survey Open-File Report 00-184, 209 p.

Holtschlag, D.J., 1994, A generalized estimate of groundwater recharge rates in the lower peninsula of Michigan: U.S. Geological Survey Water-Supply Paper 2437, 81 p.

Holtschlag, D.J., Luukkonen, C.L., and Nicholas, J.R., 1996, Simulation of ground-water flow in the Saginaw aquifer, Clinton, Eaton, and Ingham Counties, Michigan: U.S. Geological Survey Water Supply Paper 2480, 49 p.

Huffman, G.C., 1974a, Summary of ground-water hydrological data in Michigan in 1972: U.S. Geological Survey Report (unnumbered), $90 \mathrm{p}$.

Huffman, G.C., 1974b, Ground-water data for Michigan-1973: U.S. Geological Survey Report (unnumbered), $86 \mathrm{p}$.

Huffman, G.C., 1975, Ground-water data for Michigan-1974: U.S. Geological Survey Report (unnumbered), $89 \mathrm{p}$.

Huffman, G.C., 1976, Ground-water data for Michigan-1975: U.S. Geological Survey Open-File Report 77-139, $56 \mathrm{p}$.

Huffman, G.C., 1977, Ground-water data for Michigan-1976: U.S. Geological Survey Open-File Report 77-782, $56 \mathrm{p}$.
Huffman, G.C., 1979a, Ground-water data for Michigan-1977: U.S. Geological Survey Open-File Report 79-332, $75 \mathrm{p}$.

Huffman, G.C., 1979b, Ground-water data for Michigan-1978: U.S. Geological Survey Open-File Report 80-002, $61 \mathrm{p}$.

Huffman, G.C., 1980, Ground-water data for Michigan-1979: U.S. Geological Survey Open-File Report 80-1212, $56 \mathrm{p}$.

Huffman, G.C., 1981, Ground-water data for Michigan-1980: U.S. Geological Survey Open-File Report $81-811,57 \mathrm{p}$.

Huffman, G.C., 1982, Ground-water data for Michigan-1981: U.S. Geological Survey Open-File Report 82-754, $55 \mathrm{p}$.

Huffman, G.C., 1983, Ground-water data for Michigan-1982: U.S. Geological Survey Open-File Report 83-753, $54 \mathrm{p}$.

Huffman, G.C., 1984, Ground-water data for Michigan-1983: U.S. Geological Survey Open-File Report 84-623, $47 \mathrm{p}$.

Huffman, G.C., 1985, Ground-water data for Michigan-1984: U.S. Geological Survey Open-File Report $85-420,50 \mathrm{p}$.

Huffman, G.C., 1986, Ground-water data for Michigan-1985: U.S. Geological Survey Open-File Report $86-417 \mathrm{~W}, 50 \mathrm{p}$.

Huffman, G.C., 1988, Ground-water data for Michigan-1986: U.S. Geological Survey Open-File Report 88-87, $52 \mathrm{p}$.

Huffman, G.C., and Thompson, T., 1971, Summary of groundwater hydrological data in Michigan in 1970: U.S. Geological Survey Open-File Report 72-173, 94 p.

Huffman, G.C., and Thompson, T., 1973, Summary of groundwater hydrological data in Michigan in 1971: U.S. Geological Survey Report (unnumbered), 88 p.

Huffman, G.C., and Whited, C.R., 1988, Ground-water data for Michigan -1987: U.S. Geological Survey Open-File Report 88-704, 56 p.

Huffman, G.C., and Whited, C.R., 1989, Ground-water data for Michigan -1988: U.S. Geological Survey Open-File Report 89-597, 54 p.

Huffman, G.C., and Whited, C.R., 1991, Ground-water data for Michigan - 1989: U.S. Geological Survey Open-File Report 91-55, $51 \mathrm{p}$. 
Huffman, G.C., and Whited, C.R., 1993, Ground-water data for Michigan-1990: U.S. Geological Survey Open-File Report 92-114, $51 \mathrm{p}$.

Luukkonen, C.L., Grannemann, N.G., and Holtschlag, D.J., 1997a, Ground-water flow in the Saginaw aquifer in the vicinity of the north Lansing well field, Lansing, Michigan-Part 1, Simulations with a regional model: U.S. Geological Survey Open-File Report 97-569, 13 p.

Luukkonen, C.L., Grannemann, N.G., and Holtschlag, D.J., 1997b, Ground-water flow in the Saginaw aquifer in the vicinity of the north Lansing well field, Lansing, Michigan-Part 2, Simulations with a regional model using a reduced cell size: U.S. Geological Survey Open-File Report 97-570, $25 \mathrm{p}$.

Luukkonen, C.L., and Simard, Andreanne, 2004, Simulation of ground-water flow in the Vevay Township area, Ingham County, Michigan: U.S. Geological Survey Open-File Report 2004-1270, 34 p.

Mandle, R.J., and Westjohn, D.B., 1989, Geohydrologic framework and groundwater flow in the Michigan basin in Swain, L.A., and Johnson, A.I., eds., Regional aquifer systems of the United States, Aquifers of the Midwestern area: 24th Annual Conference of American Water Resources Assoc., Milwaukee, Wis., 1988, AWRA Monograph Series 13 , p. 83-109.

Marsily, Ghislain de, 1986, Quantitative hydrogeology: Orlando, Fla., Academic Press, 440 p.

McDonald, M.G., and Harbaugh, A.W., 1988, A modular three-dimensional finite-difference ground-water-flow model: U.S. Geological Survey Techniques of WaterResources Investigations, book 6, chap. A1, 576 p.

Michigan Department of Environmental Quality, 2009, Groundwater Mapping Project, accessed August 11, 2009 , at http://gwmap.rsgis.msu.edu/

Morrissey, D.J., 1989, Estimation of the recharge area contributing water to a pumped well in a glacial drift, river-valley aquifer: U.S. Geological Survey Water-Supply Paper 2338, $41 \mathrm{p}$.

Panno, S.V., Hackley, K.C., and Greenburg, S., 2002, Source identification of sodium and chloride in natural watersPreliminary results, in Proceedings of the 12th Annual Research Conference of the Illinois Groundwater Consortium-Research on agrichemicals in Illinois, groundwater status, and future directions XII: Carbondale, Ill.

Panno, S.V., Hackley, K.C., Hwang, H.H., Greenburg, S.E., Krapac, I.G., Landsberger, S., and O'Kelly, D.J., 2006, Characterization and identification of $\mathrm{Na}-\mathrm{Cl}$ sources in ground water: Ground Water, v. 44, no. 2, p. 176-187.
Pollock, D.W., 1989, Documentation of computer programs to compute and display pathlines using results from the U.S. Geological Survey modular three-dimensional finite-difference ground-water flow model: U.S. Geological Survey Open-File Report 89-381, 188 p.

Reilly, T.E., and Pollock, D.W., 1993, Factors affecting areas contributing recharge to wells in shallow aquifers: U.S. Geological Survey Water-Supply Paper 2412, 21 p.

Richter, B.C., and Kreitler, C.W., 1993, Geochemical techniques for identifying sources of groundwater salinization: Boca Raton, Fla., C.K. Smoley, 258 p.

Rutledge, A.T., 1993, Computer programs for describing the recession of ground-water discharge and for estimating mean ground-water recharge and discharge from streamflow records: U.S. Geological Survey Water-Resources Investigations Report 93-4121, 45 p.

Tri-County Regional Planning Commission, 1992, Tri-County regional water feasibility study: Burns and McDonnell; Snell Environmental Group; and Dickinson, Wright, Moon, Van Busen, and Freeman Report 90-338-4-005 [variously paged].

Vanlier, K.E., and Wheeler, M.L., 1968, Ground-water potential of the Saginaw Formation in the Lansing metropolitan area, Michigan: U.S. Geological Survey Open-file Report (unnumbered).

Vanlier, K.E., Wood, W.W., and Brunett, J.O., 1973, Watersupply development and management alternatives for Clinton, Eaton, and Ingham Counties, Michigan: U.S. Geological Survey Water-Supply Paper 1969, 111 p.

Westjohn, D.B., and Weaver, T.L., 1996, Hydrogeologic framework of Pennsylvanian and Late Mississippian rocks in the central Lower Peninsula of Michigan: U.S. Geological Survey Water-Resources Investigations Report 94-4107, $44 \mathrm{p}$.

Westjohn, D.B., Weaver, T.L., and Zacharias, K.F., 1994, Hydrogeology of Pleistocene glacial deposits and Jurassic "red beds" in the central Lower Peninsula of Michigan: U.S. Geological Survey Water-Resources Investigations Report 93-4152, 14 p.

Wheeler, M.L. 1967, Electric analog model study of the hydrology of the Saginaw Formation in the Lansing, Michigan area: East Lansing, Michigan State University, M.S. thesis, $74 \mathrm{p}$.

Wood, W.W. 1969, Geochemistry of ground water of the Saginaw Formation in the upper Grand River Basin, Michigan: East Lansing, Michigan State University, Ph.D. dissertation, 104 p.

Prepared by the USGS Columbus Publishing Service Center. 



\section{Appendix 1. Chemistry of Lansing-Area Well Water.}

During this study, water-chemistry data from selected Lansing-area wells were analyzed to determine any longterm changes in water quality, because water quality can affect water-treatment costs. Analysis of water-chemistry data and how these data have changed over time is important for guiding water-withdrawal decisions and ensuring a sufficient quantity of good-quality water. Water-chemistry data may differ between areas because of differences in well-construction details - such as well depth, location, and the type of geologic materials intercepted by the well-and differences in the types of materials both above and below the open interval of the well. Differences in water-chemistry data also may be due to the current and historical pumping rates of local wells, because pumping affects the rate of groundwater movement and the directions of flow paths. Pumping may induce the movement of poorer quality water near pumping centers or of contaminants from other, more distant areas or underlying aquifers.

As groundwater moves slowly through geologic materials, the composition of the water changes, usually with the addition of dissolved constituents (Freeze and Cherry, 1979). Thus, water in deeper formations that has had a longer residence time in the aquifer may have more dissolved constituents, or dissolved solids, than water that has just entered the aquifer system in recharge areas. Removal of water from storage can change the quality of the remaining water because good-quality water generally is withdrawn first.

Groundwater flows through geologic materials where different rock/water interactions or mixing may affect waterquality characteristics. In addition, water with differing constituents may mix as the water moves through the aquifer, making comparison of water quality among wells or changes through time difficult. Comparison of water-chemistry data among wells can include inspection and mathematical calculations, as well as preparation of graphs and maps to determine the relation among wells and differences spatially and over time. However, comparison of historical data may be problematic because of possible differences in water-quality analysis methods and analytes, errors in sample analysis or transcription, or unknown well-pumping history at the time samples were collected. The groundwater samples in the Lansing area have historically been analyzed by means of the same laboratory methods (Bill Maier, Lansing Board of Water and Light, oral commun., 2007). Data were compiled from more than 4,000 samples collected from 1935 to 2005 .
The composition of most natural waters can be characterized in terms of three cationic species (calcium, magnesium, and sodium) and three anionic species (bicarbonate, sulfate, and chloride). Calculation of the ratio of one ion to another or to the total sample concentration is often useful for the determination of similarities or differences among water samples (Hem, 1985).

Trilinear plotting systems are a graphical means of portraying water-chemistry data and were used as early as 1913 (Hem, 1985). The type of trilinear diagram used during this study was independently developed by Hill (1940) and Piper (1944). Use of a trilinear diagram aids in the determination of whether a water may be classified according to the predominant cation or anion, expressed in milliequivalents per liter (meq/L), and can demonstrate whether relations exist among individual samples collected at one point in time or over some time interval (Hem, 1985). A milliequivalent per liter is the unit of concentration equal to the concentration in milligrams per liter divided by the equivalent weight (atomic weight divided by valence). Each cation value, expressed as a percentage of the total concentration $(\mathrm{meq} / \mathrm{L})$ of all cations under consideration, is plotted in the lower left triangle of the diagram. Similarly, each anion value, expressed as a percentage of the total concentration $(\mathrm{meq} / \mathrm{L})$ of all anions under consideration, is plotted in the lower right triangle of the diagram. These points can then be extended into the central, diamond-shaped field by projecting them along lines parallel to the upper edges of the central field. The intersection of these projections from each lower triangle represents the composition of the water with respect to the combination of ions shown.

Water samples may be grouped by hydrologic or geologic categories for comparison and analysis (Hem, 1985). Trilinear diagrams of water samples having total dissolved solids (TDS) concentrations less than $500 \mathrm{mg} / \mathrm{L}$ and TDS concentrations greater than $1,000 \mathrm{mg} / \mathrm{L}$ are shown in figure $1-1$. Samples with lower TDS generally plot along the leftmost corner of the middle diamond, whereas samples with higher TDS generally plot over a larger area of the middle diamond. Water samples with lower TDS are classified as the calcium-bicarbonate type (Kehew, 2001) because the dominant major ions in the sample are calcium and bicarbonate (fig. 1-1A). In water samples with higher TDS, calcium also is generally the dominant cation; however, magnesium and sodium are high in some samples (fig. 1-1B). Water from these samples generally does not have a dominant anion because bicarbonate, chloride, and sulfate all are present in appreciable amounts in some samples. 
A

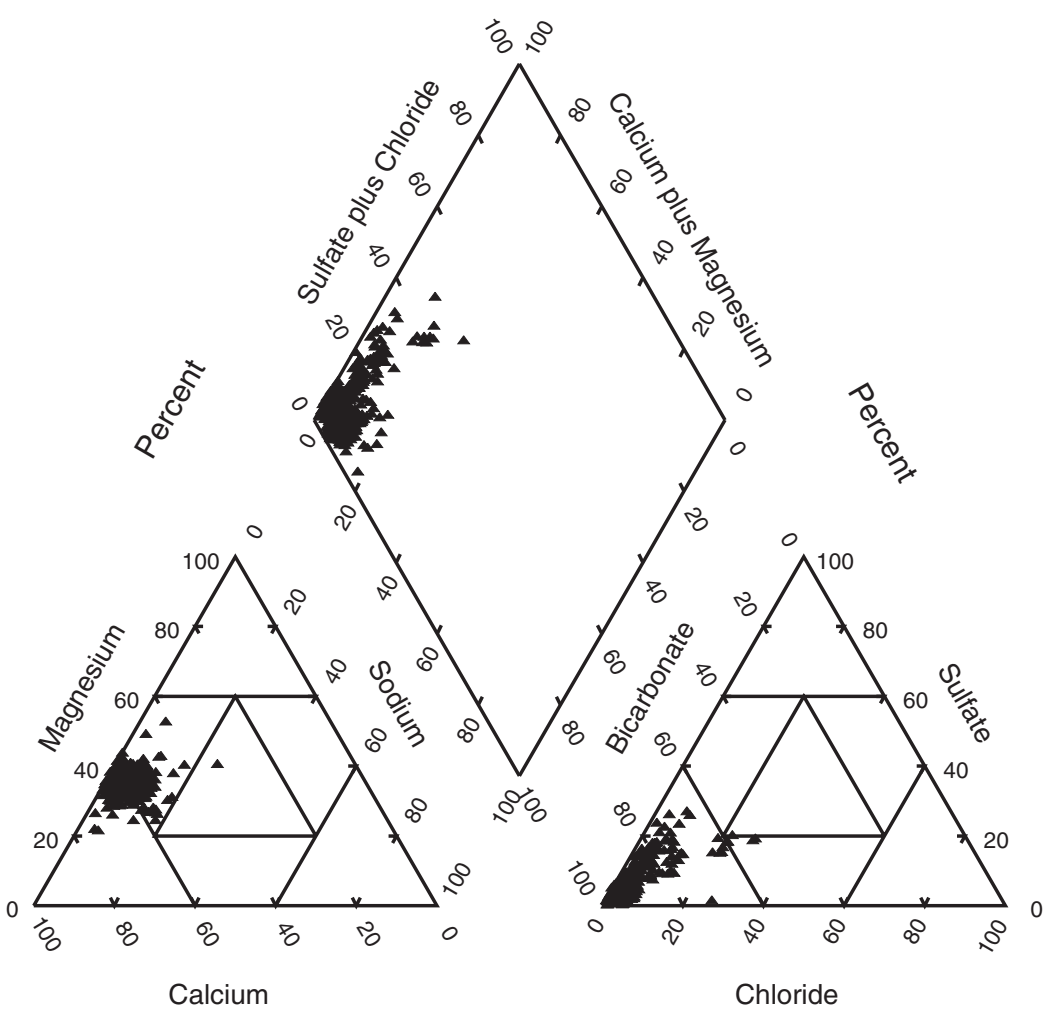

Percent

B

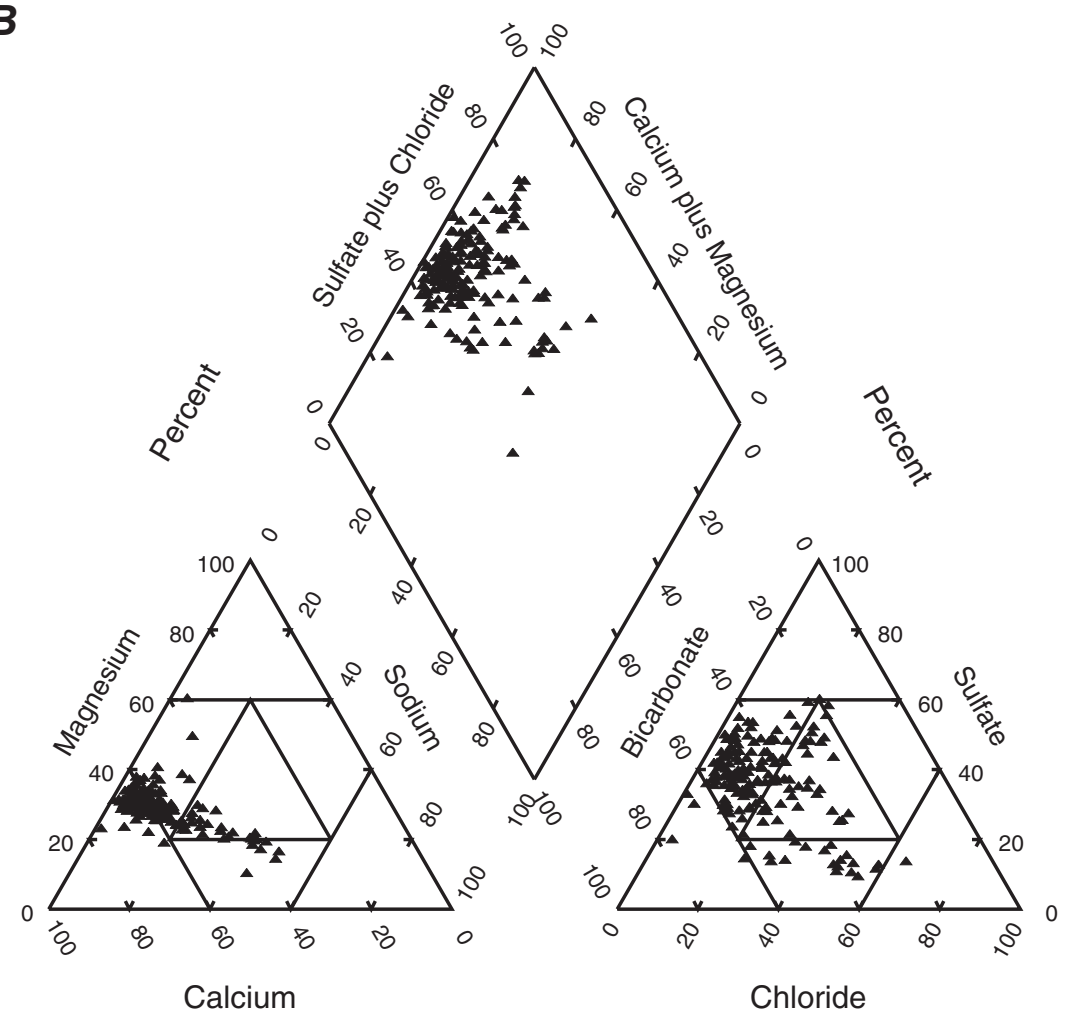

Percent

Figure 1-1. Trilinear diagrams of Lansing area, Michigan, groundwater samples. $A$, Total dissolved solids (TDS) concentrations less than 500 , and $B$, greater than 1,000 milligrams per liter. 
Within the Tri-County region, the hardness and alkalinity of groundwater are important considerations in optimization scenarios because these water-quality properties affect water treatment. Waters with high alkalinity and low hardness require less treatment and thus are less costly for the municipal water provider to treat. Hardness is generally defined in terms of calcium and magnesium and is expressed in terms of an equivalent concentration of calcium carbonate. The alkalinity of a solution may be defined as the capacity for the solutes it contains to react with and neutralize acid. In almost all natural waters, alkalinity is produced by dissolved carbon dioxide, bicarbonate, and carbonate (Hem, 1985). From samples collected in 2003-5, hardness, as $\mathrm{CaCO}_{3}$, ranges from 280 to $1,200 \mathrm{mg} / \mathrm{L}$ and is highest in the east-central Lansing area and lowest in south Lansing (fig. 1-2). Alkalinity ranges from 260 to $480 \mathrm{mg} / \mathrm{L}$ and also is highest in the east-central Lansing area and lowest in south Lansing.

Box plots are another graphical means to allow comparison of data from different time periods or different areas. Figure 1-3 shows major ion concentrations of samples for time intervals from 1930-38 up to 1996-2005. The samples collected in the 1930s and 1940s are assumed to represent background conditions because these wells were often pumped for an extended time before sample collection (and thus concentrations are believed to be representative of water quality from the aquifer), and samples were collected at a time of low total withdrawals in the area. Concentrations of calcium, magnesium, and sulfate were slightly lower during the middle time periods and higher in the early and later periods; the early and later concentrations were close to the median background concentrations. Bicarbonate concentration was lower during the later period, but sodium and chloride concentrations generally were higher during that period. Figure 1-4 shows majorion concentrations for samples from north and south Lansing areas. The median values are similar between areas for calcium, magnesium, and sodium; median values are slightly lower for sulfate and slightly higher for chloride in samples from south Lansing. Median values are lower for bicarbonate in samples from south Lansing compared to samples from north Lansing. For all major ions, the ranges and maximum concentrations are less for water samples from the south area.
The data were further subdivided to consider only the northern wells because of the change in pumping distribution since the 1970s. These northern wells were generally pumped more before 1970 than they were after 1970, when pumping was spread out over a larger area (fig. 4). Trilinear diagrams of water samples collected before 1970 and after 1970 from 78 northern wells and from 11 wells collected before 1970 are shown in figure 1-5. Four wells (PW A, PW B, PW C, and PW D) are shown in each graph as an indication of how sample concentrations have changed over time. Samples from PW A and PW B indicate higher calcium and a broader range of bicarbonate concentrations after 1970. Samples from PW C and PW D also indicate changes in bicarbonate and chloride concentrations between the two time periods. Water collected from wells before 1970 is generally characterized by higher concentrations of sodium, bicarbonate, sulfate, and chloride than water collected from these wells after 1970. Samples collected before 1970 are generally characterized by either high chloride and low sulfate concentrations or low chloride and high sulfate concentrations; after 1970, samples indicate generally higher sulfate and lower chloride concentrations (fig. 1-6). However, the shift in pumping does not completely explain these differences. Not all water samples in the preand post-1970 groups show the same trends in concentrations (fig. 1-7). The median and range in concentrations were generally higher for calcium, magnesium, chloride, and sulfate in the post-1970 group. The median bicarbonate concentration was about the same; however, the range was larger after 1970. The range of concentrations for both chloride and sodium are less for the post-1970 samples. Other factors were considered in an attempt to explain the observed trends in the data: well-construction details such as well depth, well location, total rock thickness, drift thickness, sandstone thickness, shale thickness, and degree of connection between the bedrock and glacial units, known pumping history, and time interval. Considered individually, these factors do not explain the data trends. Further analysis including multiple factors is needed to better explain the observed data trends and water-quality changes. 


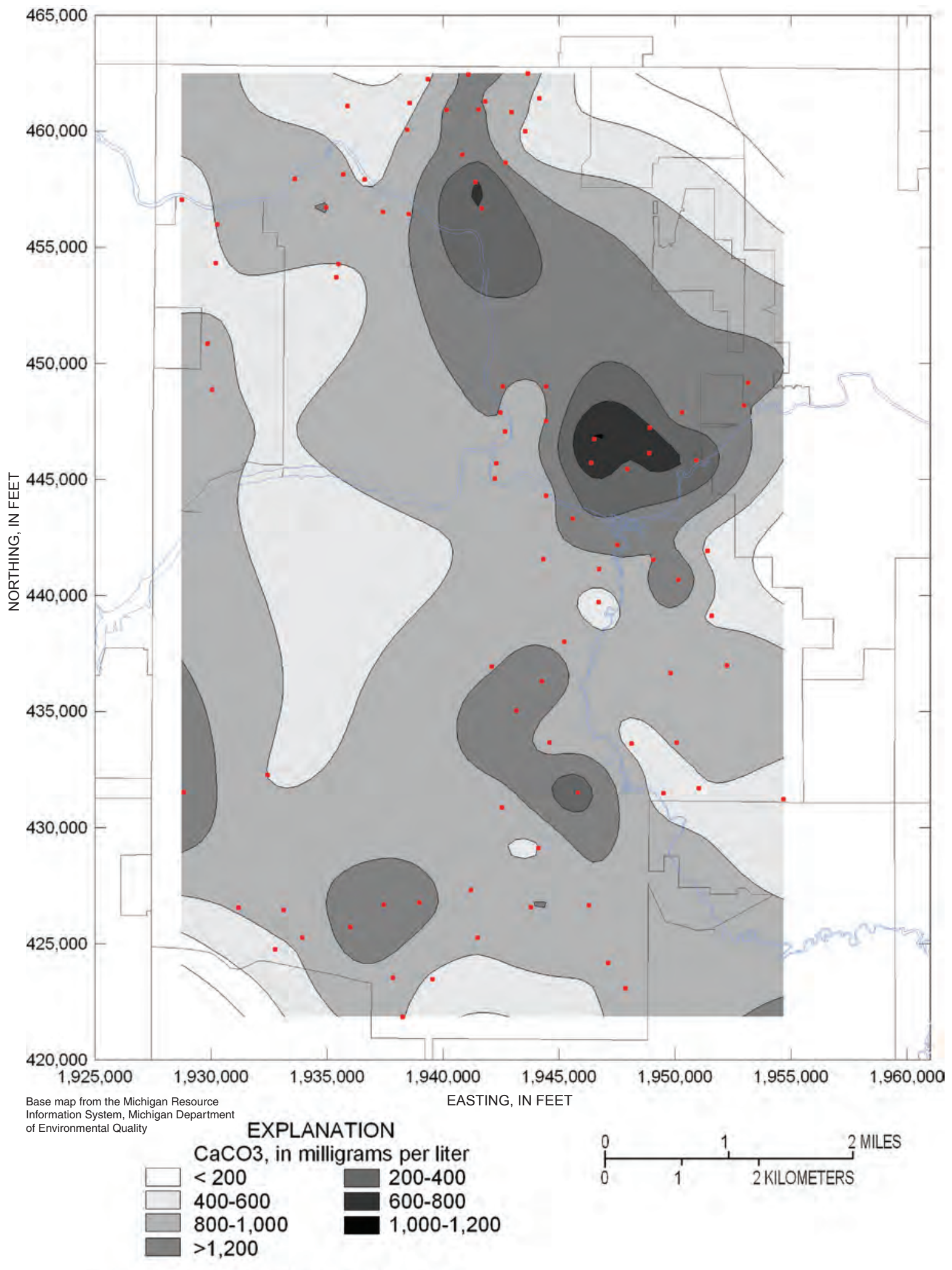

- Groundwater sample location

Figure 1-2. Distribution of hardness, in milligrams per liter $\mathrm{CaCO}_{3^{\prime}}$, from samples from 2003-5, Lansing area, Michigan. 

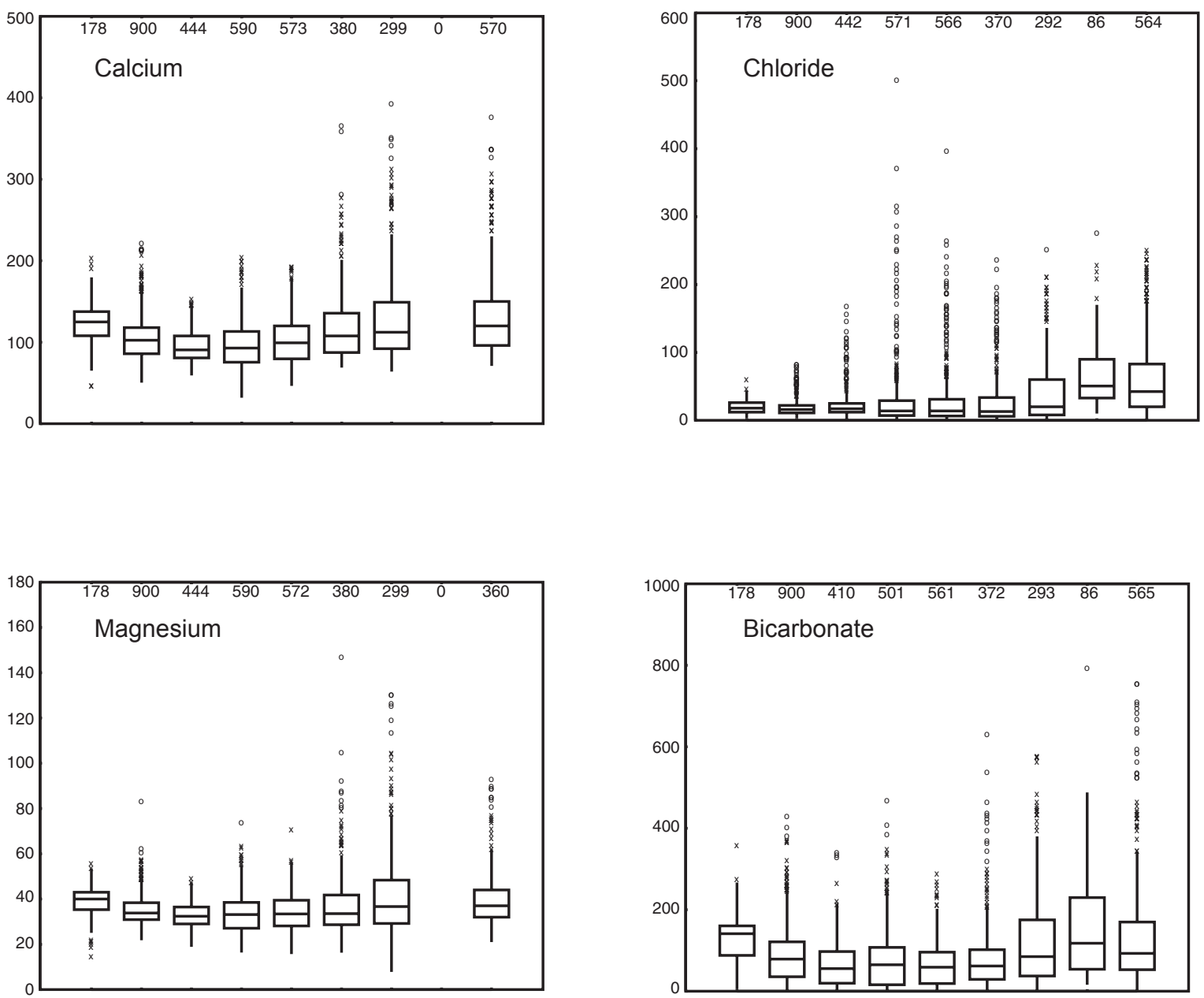

EXPLANATION

Schematic boxplot

30 Number of values

- Upper detached
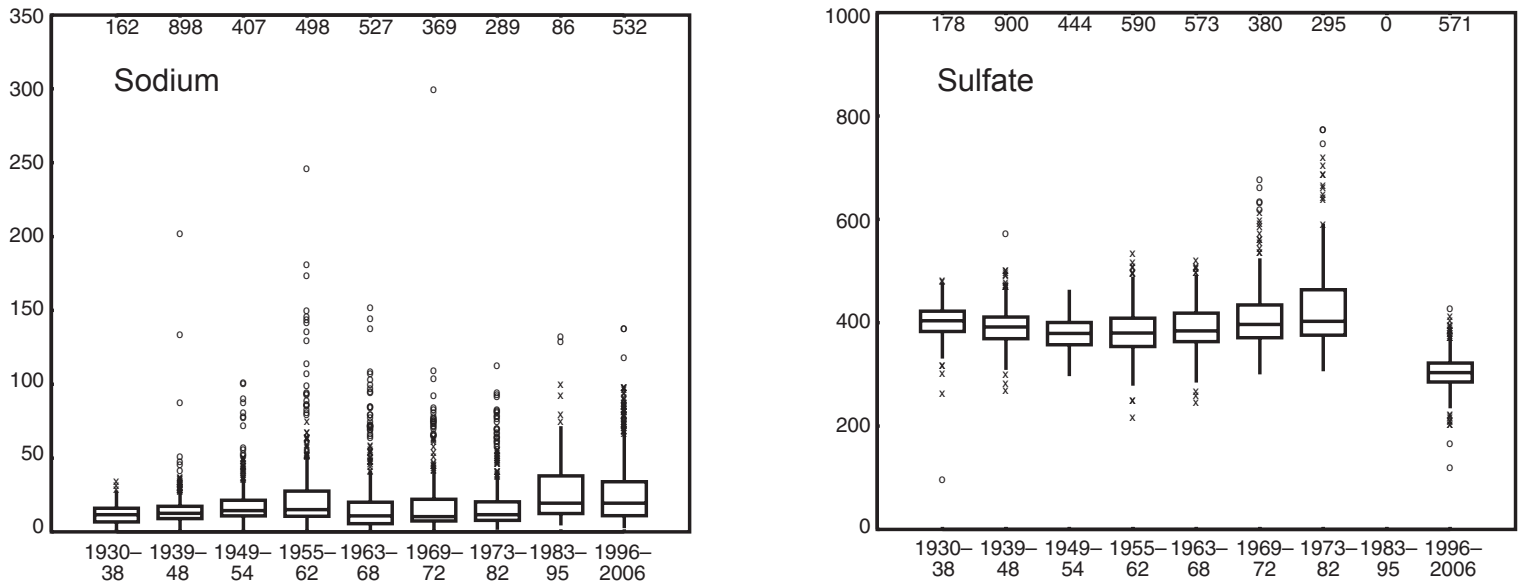

$x$ Upper outside

Upper adjacent

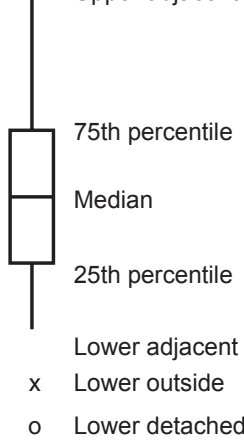

Figure 1-3. Major ion concentrations, in milligrams per liter, for 1930-2006, Lansing area, Michigan. (Note the difference in scales on the y-axis.) 


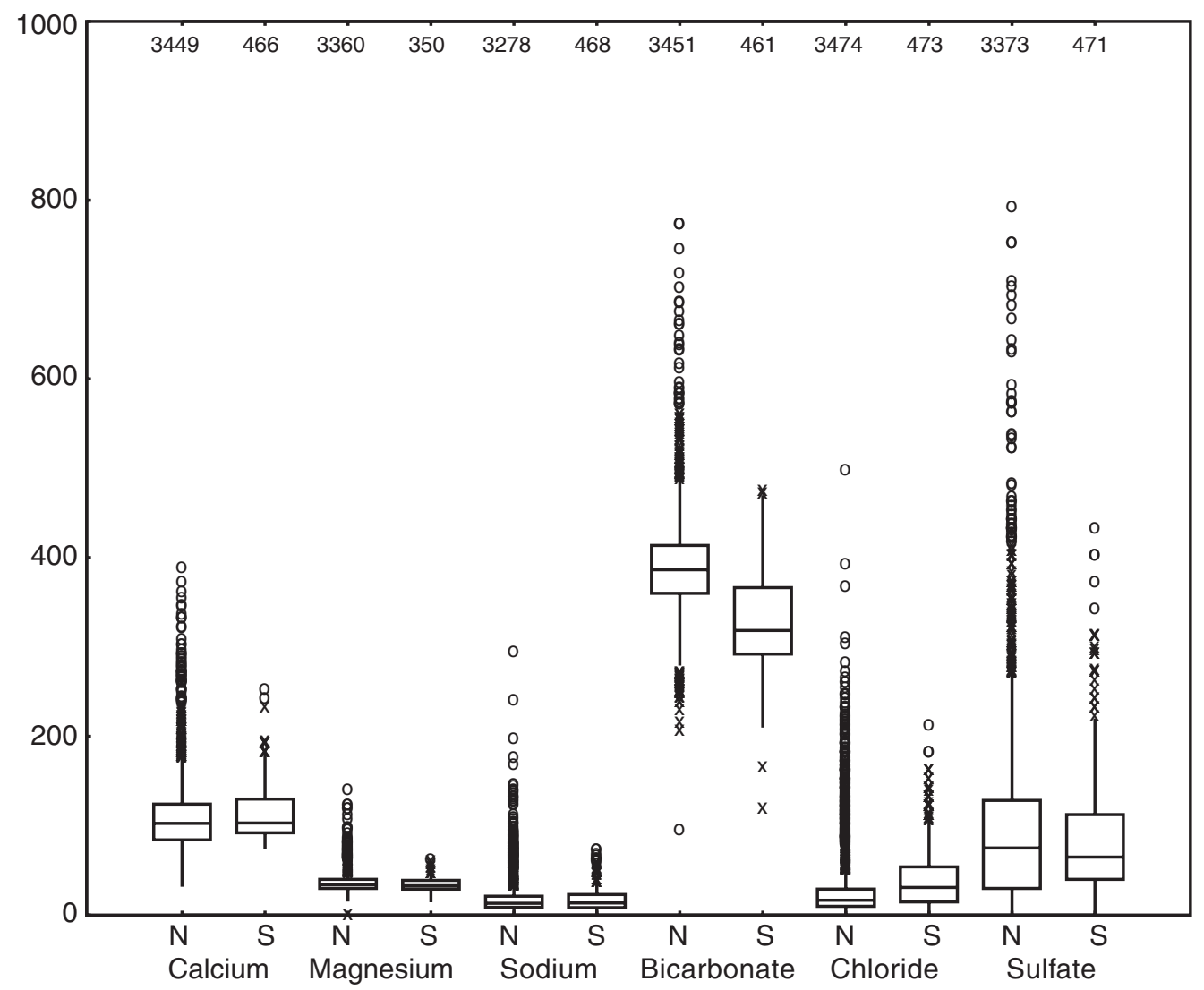

EXPLANATION

Schematic boxplot

30 Number of

- Upper detached

x Upper outside

Upper adjacent

75th percentile

Median

25th percentile Lower adjacent $x$ Lower outside

- Lower detached

Figure 1-4. Major ion concentrations for northern and southern wells for 1930-2005, Lansing area, Michigan. 
$\boldsymbol{A}$

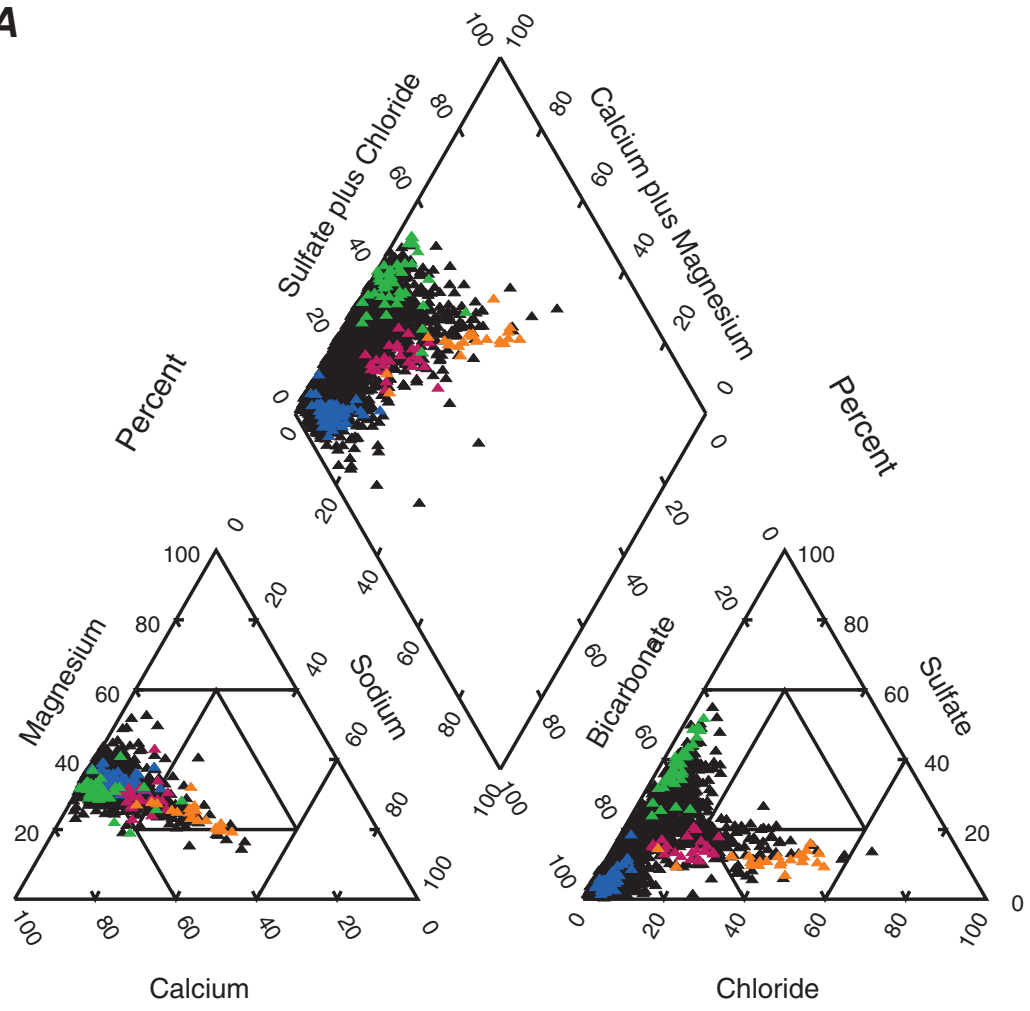

Percent

B

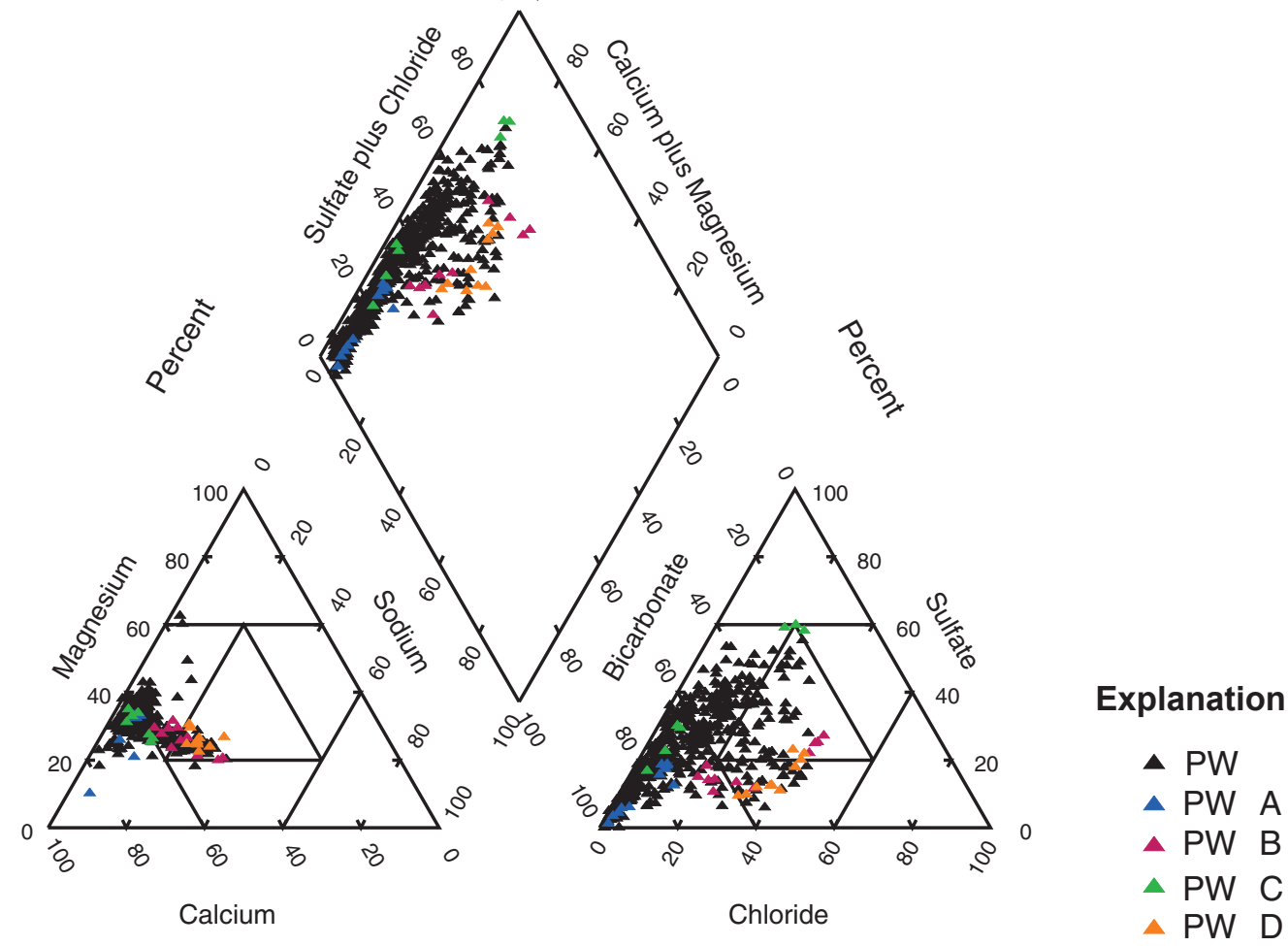

Percent

Figure 1-5. Trilinear diagrams of water samples collected from northern Lansing area, Michigan, wells $A$, before 1970, and $B$, after 1970 . 


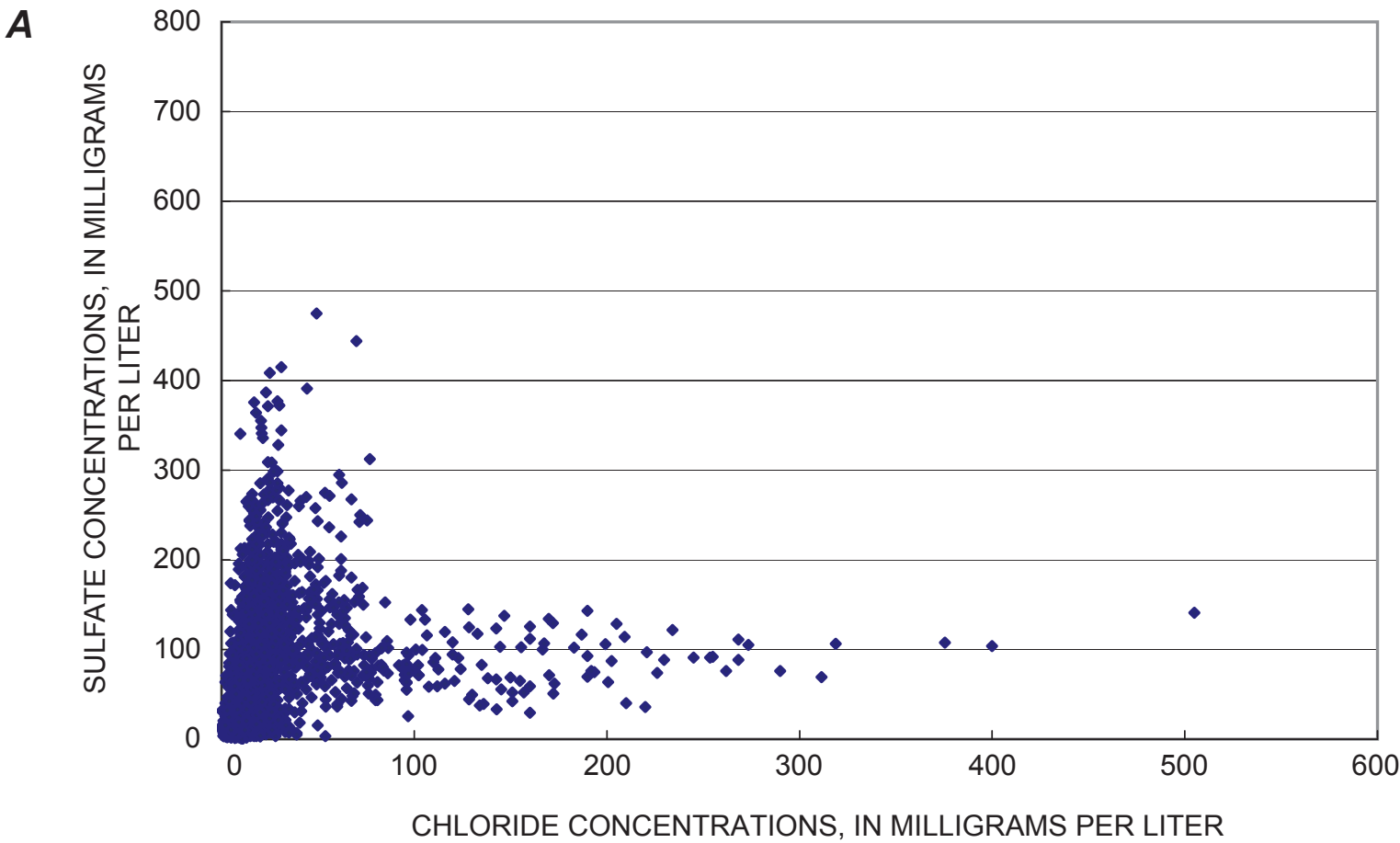

B

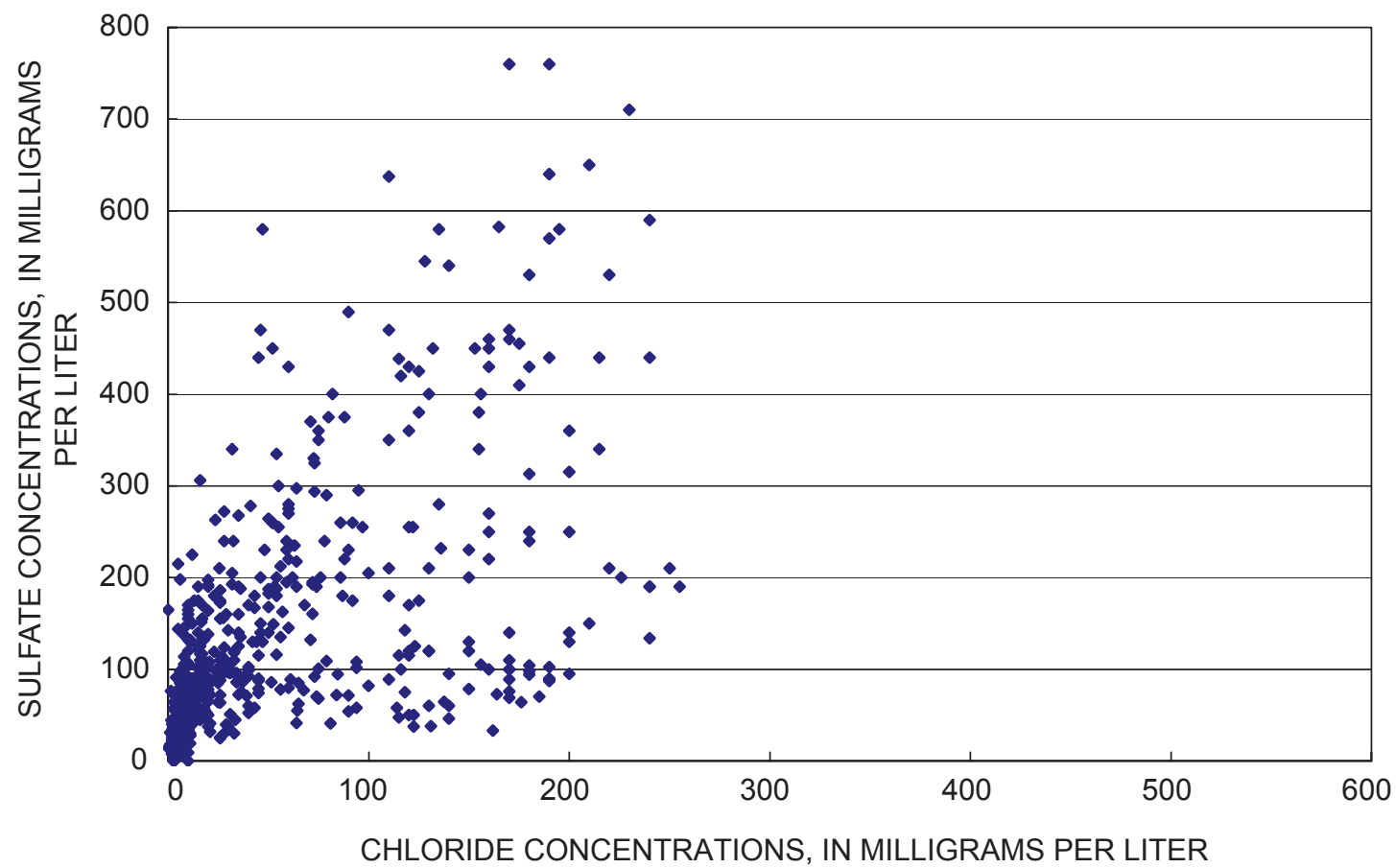

Figure 1-6. Relation of chloride to sulfate concentrations collected from northern Lansing area, Michigan, wells $A$, before 1970 , and $B$, after 1970 . 


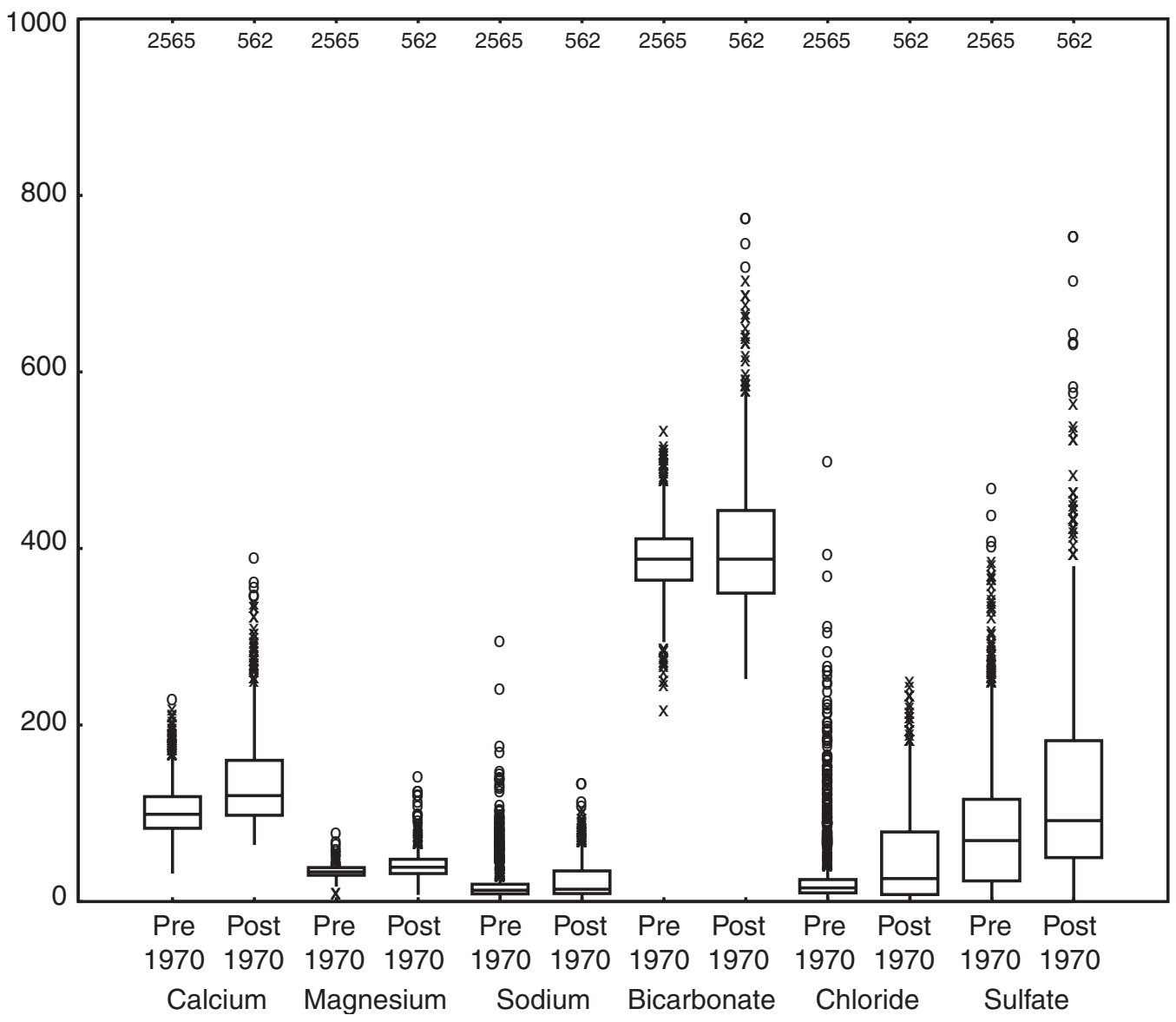

EXPLANATION

Schematic boxplot

30 Number of

values

o Upper detached

$x$ Upper outside

Upper adjacent

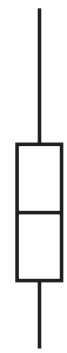

$x$ Lower outside

- Lower detached

Figure 1-7. Comparison of major-ion concentrations from water samples collected from northern Lansing area, Michigan, wells before and after 1970 .

\section{References Cited}

Freeze, R.A., and Cherry, J.A., 1979, Groundwater: Englewood Cliffs, N.J., Prentice-Hall, 604 p.

Hem, J.D., 1985, The study and interpretation of the chemical characteristics of natural water ( $3 d$ ed.): U.S. Geological Survey Water-Supply Paper 2254, 264 p.

Hill, R.A. 1940, Geochemical patterns in Coachella Valley, California: American Geophysical Union Transactions, v. 21, p. $46-49$.

Kehew, A.E., 2001, Applied chemical hydrogeology: Upper Saddle River, N.J., Prentice Hall, 368 p.

Piper, A.M. 1944, A graphic procedure in the geochemical interpretation of water analyses: American Geophysical Union Transactions, v. 25, p. 914-923. 


Luukkonen-Model Refinement and Simulation of Groundwater Flow in Clinton, Eaton, and Ingham Counties, Michigan-SIR 2009-5244

\section{ZUSGS}

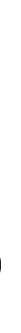

